\title{
The Market for Legal Innovation: Law and Economics in Europe and the United States
}

Nuno Garoupa

ngaroup@gmu.edu

Thomas S. Ulen

Follow this and additional works at: https://scholarship.law.tamu.edu/facscholar

Part of the Law Commons

\section{Recommended Citation}

Nuno Garoupa \& Thomas S. Ulen, The Market for Legal Innovation: Law and Economics in Europe and the United States, 59 Ala. L. Rev. 1555 (2008).

Available at: https://scholarship.law.tamu.edu/facscholar/521

This Article is brought to you for free and open access by Texas A\&M Law Scholarship. It has been accepted for inclusion in Faculty Scholarship by an authorized administrator of Texas A\&M Law Scholarship. For more information, please contact aretteen@law.tamu.edu. 


\title{
THE MARKET FOR LEGAL INNOVATION: LAW AND ECONOMICS IN EUROPE AND THE UNITED STATES
}

\author{
Nuno Garoupa $a^{1,2}$ \\ Thomas S. Ulen ${ }^{3}$
}

ABSTRACT ................................................... 1556

I. INTRODUCTION .............................................. 1557

II. WHAT IS A "LEGAL INNOVATION"? AND WHAT COUNTS AS "LAW AND ECONOMICS"? .......................................... 1564

III. DIFFERENCES BETWEEN THE UNITED STATES AND EUROPE WITH RESPECT TO THE RECEPTION OF LAW AND ECONOMICS ........... 1568

IV. SOME POSSIBLE REASONS FOR THESE DIFFERENCES ............. 1578

A. Political Ideology ............................................... 1579

B. Money and the Success of Law- and-Economics ................ 1582

C. Common Law versus Civil Law................................ 1587

D. The Structure of Legal Education ............................ 1592

1. We are grateful to Gonçalo Almeida Ribeiro, Iraj Babaei, Assunção Cristas, Ben Depoorter, Gerrit de Geest, Bertrand du Marais, Lee Anne Fennell, Samuel Ferey, Oren Gazal-Ayal, Tom Ginsburg, Fernando Gomez-Pomar, Hank Greeley, Stefan Grundmann, Aristides Hatzis, Dirk Heremans, Hein Koetz, Dennis Khong, Russell Korobkin, Pedro Magalhāes, Henry Manne, Francisco Marcos, Richard McAdams, Steven Medema, Nicholas Mercuro, Wolfgang Oehler, Anthony Ogus, Ariel Porat, Larry Ribstein, Daria Roithmayr, Stephen Ross, Maria Alessandra Rossi, Pablo Salvador, Eli Salzberger, Hans-Bernd Schäfer, Kyung Soon Song, Justice Robert Steigmann, Guilherme Vilaça, Gerhard Wagner, and Omri Yadlin for comments on earlier drafts and their discussions with us about these matters. We are also grateful to participants at workshops at the University of Illinois College of Law, the Comparative Law and Economics Forum, the University of Pompeu Fabra, the Graduate College of Law and Economics of the University of Hamburg, the Faculty of Law at the University of Ghent, the Faculty of Law at the University of Haifa, the Faculty of Law at the University of Ljubljana, the 2005 Annual Meeting of the Israeli Law and Economics Association, the 2005 Annual Meeting of the Asian Law and Economics Association, the Faculty of Law at the University of Rotterdam, the Faculty of Law at the University of Nancy, the Faculty of Economics at the University of ParisNanterre, the Faculty of Law at the University of Amsterdam, the Instituto de Empresa (Madrid), the Fondation Aimé De Caluwé and DCH (at the Cercle de Lorraine in Brussels), and the Lisbon Discussion Group in Public Policy and Institutions for their invitations to speak and for the valuable comments. Nuno Garoupa acknowledges financial support by Nova Forum and FCT, POCI/JUR/55752/2004. assistance.

We would like to thank Danieli Arbex, Ted Ulen, and Ariel Yehezkel for marvelous research

2. Professor of Law, University of Illinois College of Law and University of Manchester School of Law, and Research Professor, IMDEA (Madrid). B.A., Universidade Nova de Lisboa; M.Sc., Queen Mary College, U.K.; LL.M., University of London; Ph.D., University of York.

3. Swanlund Chair, University of Illinois at Urbana-Champaign; Professor of Law, University of Illinois College of Law; and Director of the Illinois Program in Law and Economics. 
1. Law as a Graduate or Undergraduate Education ............ 1593

2. Competition in Higher and Legal Education ................. 1597

$E$. The Treatment of the Legal Professoriate ...................... 1603

1. Tenure and Legal Publications............................... 1603

2. Compensation for Law Professors .......................... 1605

F. Utilitarianism versus Kantianism.............................. 1607

G. Legal Realism ............................................... 1608

H. The Great Man or Woman Theory ............................ 1611

1. Legal Culture........................................................ 1614

J. Informational and Reputational Cascades ...................... 1616

K. Summary and Conclusions .................................... 1619

V. A MODEL OF THE MARKET FOR LEGAL INNOVATION ............. 1620

$A$. The General Elements of the Economic Theory of Innovation .. 1620

B. Demand Determinants of Legal Innovation ....................... 1622

C. Supply Determinants of Legal Innovation ....................... 1627

D. Market Structure Determinants............................... 1631

VI. ConCLUSION .................................................. 1633

\section{ABSTRACT}

There have been a large number of innovations in legal scholarship in the U.S. legal academy over the past twenty-five or so years and very few from legal scholars in other parts of the world. For instance, because both of us work in the area of law and economics, we are both acutely aware of the large differences in the receptivity to law and economics as between the United States and Europe. The U.S. legal academy has generously embraced law and economics (and some other legal innovations), while Europe (and the rest of the world) has not. Why has the United States led the world in the production and adoption of legal scholarly innovations? This Article seeks to answer that question generally and with particular reference to law and economics.

In Part II we deal with two definitional issues-what we mean by a "legal innovation" and what counts as "law and economics." The scholarly innovations on which we focus are new methods of looking at many areas of the law, such as feminist jurisprudence, or the articulation of the principles and boundaries of an entire new area of law, such as elder law. By "law and economics" we mean the application of economic analysis to any of the area to which its application would not be obvious. Then in Part III we offer a series of anecdotes and empirical studies designed to show that law and economics is much more prominent in U.S. legal scholarship than in European legal scholarship.

We then seek, in Part IV, explanations for the differences between the United States and European legal academies in their production and adop- 
tion of legal scholarship innovations generally and with respect to law and economics particularly. Our central claim is that it is the competitiveness of higher and legal education in the United States that is the principal explanation for the scholarly innovativeness of the United States and the lack of competition (and the consequent lack of an incentive to innovate) in European higher and legal education that explains the differences. We further hypothesize that the production and adoption of law and economics are attractive only to those who have experienced a prior legal scholarly innovation-legal realism. We draw a clear line of intellectual heritage from legal realism to law and economics.

Before settling on competition and legal realism as the principal explanations for the production and adoption of legal scholarship innovations, we canvass (and reject) a large number of alternative explanations, such as political ideology, money, the differences between common and civil law systems, the structure of legal education, and more.

In Part $V$ we draw a connection between the standard economic theory of innovation and diffusion and our observations in the prior four parts of the Article. That economic theory of innovation and diffusion identifies three factors-demand, supply, and market structure-as determining the presence and pace of innovation and diffusion. We relate each of those factors to observable differences between the United States and Europe, showing that our explanation of the production and adoption of legal scholarly innovations follows the same factors as does the economic theory of innovation in production techniques.

\section{INTRODUCTION}

Our subject in this paper is legal innovation-specifically, innovation in the legal academy in how scholars think and write about the law. We seek to describe and explain the complex process by which a scholarly innovation first appears and gains acceptance (or not) within the legal profession. We hope to isolate the factors that generate legal innovations and contribute to their acceptance.

While we shall address this topic at a very general level, we shall also seek to apply that general model to a particular innovation of the last quarter-century-the economic analysis of law. We want to explain what we and many others perceive to be a significant and interesting difference between the reception of law and economics in North America and in the rest of the world. In the United States and Canada, law and economics has been warmly received in law schools and somewhat less warmly but, nonetheless, graciously received in economics departments. In contrast, law and economics has been given a relatively cold shoulder in European 
law schools but has been somewhat more pleasantly taken in by European economics departments. ${ }^{4}$ In summary, law and economics has been one of the most important developments in North American legal scholarship of the twentieth century but has hardly registered as a scholarly innovation in Europe. Why this great difference in the reception accorded law and economics? Is law and economics destined to be a purely North American phenomenon? Or will other parts of the world eventually adopt it as an important or even central method for examining and reforming law? ${ }^{5} \mathrm{At}$ the risk of sounding repetitious, we stress that law and economics is merely an example of the more general topic of why some legal academies engage in scholarly innovations and others do not, and an illustration of why some innovations succeed and others do not.

This Article offers answers to those questions raised above within the context of a broader theory of legal scholarly innovation. In brief, we argue for one central proposition that we believe explains differences in the production of and receptivity to scholarly innovations in the legal academy, and a subsidiary proposition that explains the degree of interest in and receptivity to legal innovations from scholarly disciplines contiguous to law, such as economics.

The overarching central proposition is that the greater the competition for resources within the legal academy-that is, among independent law schools-then the more likely it is to produce and adopt scholarly innovations. If, for example, there are multiple law schools within a nation and they compete for faculty members, students, grants and contracts, and other resources, then we hypothesize that there may be a strong incentive to innovate in each of these law schools. Those law schools that are able to offer, say, more certain and better placements of their graduates in interesting and better-paying jobs as lawyers may attract better students. Those schools that are known to have productive and innovative faculty members whose students receive, therefore, better legal training are likely to attract better students and, possibly, more talented younger scholars who desire to be close to the productive and innovative older faculty. And nonacademic members of the public who are eager, for instance, to have a powerful report in favor of a particular position on some issue of public

4. In Part III we shall draw some more nuanced distinctions among the countries of Europe with respect to their receptivity to law and economics and shall also consider the state of receptivity in other parts of the world, such as East Asia, South Asia, Africa, the Middle East, and Central and South America.

5. It is difficult to think of highly successful legal innovations that have emerged from legal scholars working in countries outside of North America. Emblematic of our point is deconstruction or interpretive theory. Although Habermas, among others, applied the insights of that innovation to legal topics, see, for example, Hugh Baxter, Habermas's Discourse Theory of Law and Democracy, 50 BUFF. L. REV. 205 (2002), the principal legal applications of interpretivism to law occurred in North America. For a critical view of those applications, see Michael S. Moore, The Interpretive Turn in Modern Theory: A Turn for The Worse?, 41 STAN. L. REV. 871 (1989). 
moment are more likely to seek the counsel of faculty at better law schools.

There is some reason to believe that this competition might take place only within and not across national borders. The market for legal talent is frequently local or regional or, at best, national. It is rarely international. There are obvious reasons for this: in their widest reach laws tend to be national, and there may be language barriers that make law accessible only to localized populations. As a result, the competitiveness of the legal academy may be-to borrow a famous phrase from economics-limited by the scope of the market. ${ }^{6}$ For small national markets, there may be relatively little competition while for large jurisdictions, such as the United States and the European Union, there may be greater scope for competition and, therefore, for legal scholarly innovation.

We do not intend to make too much of these geographic and market limitations in what follows. First, there is an important sense in which the market for legal academic resources stretches across national borders. The two of us, for example, are from different countries. And we each interact routinely with legal scholars from around the world, as the first footnote indicates. Moreover, what counts for our hypothesis is behavior, not geography and numbers. Consider that there may be a small country with only one law school and a large country with hundreds of schools. If the small country law school competes with law schools all over the world for the best talent, whether student or faculty; seeks to have its law review serve as a publishing outlet for the best legal scholarship in the world; and in other ways attempts to play on the world, rather than the national, stage, then that law school is competing vigorously and may generate legal scholarly innovations. In contrast, the numerous law schools in the large country may have an implicit agreement among themselves not to compete but, like local commuter schools, to focus only on their local or regional market and to enjoy the relatively quiet life of near monopolists.

In our view, the largest countries-China and India, comprising $40 \%$ of the world's population ${ }^{7}$-have been, until recently, largely immune to the competitive forces in higher education that we champion; and the European Union, taken as a whole rather than as a collection of twentyseven individual countries, has not experienced much competition within and across its higher-education systems, although we believe that situation is changing. And some of the smaller countries-such as the Netherlandshave been leaders in legal innovation. ${ }^{8}$ So, there is no obvious correlation

6. See Adam SMith, The Wealth OF Nations 17-21 (Edwin Cannan ed., Random House 1937) (1776).

7. See U.S. Census Bureau, International Data Base, Countries and Areas Ranked by Population: 2007, http://www.census.gov/cgi-bin/ipc/idbrank.pl (last visited Oct. 1, 2007).

8. See S.I. Strong, Intervention and Joinder as of Right in International Arbitration: An Infringement of Individual Contract Rights or a Proper Equitable Measure?, 31 VAND. J. TRANSNAT'L 
between nation size and the degree of competitiveness within the higher education or legal education markets.

Second, we believe that there are indications that the connection between national, regional, and local jurisdiction and legal education is in a transitional phase-that legal academics around the world are at an early stage of forging the same international scholarly community that characterizes many other academic disciplines. ${ }^{9}$

Clearly, we see within the legal academy, and higher education more generally, some of the same beneficent effects of competition that economists posit as following from vigorous but fair competition in the markets for goods and services. ${ }^{10} \mathrm{We}$ shall pursue that analogy more explicitly in Part $\mathrm{V}$ below, where we elaborate on the connections between our hypothesis and the standard economic account of innovation. Here we simply draw attention to the fact that a competitive educational industry shares many of the same characteristics as a competitive product market. Some may blanch at the comparison, but we think that it is fruitful, particularly to explain the developments in legal scholarship and education of the past twenty years or so and to predict changes in the future.

Invoking the competitive aspects of the legal academy raises a host of important questions, such as those having to do with the appropriate amount of regulation of the legal academy so as to minimize problems of anticompetitiveness and external cost and to secure the social returns accruing from public goods and external benefits. And, of course, if a case is made for regulation of the competitive legal academy in the public interest, then there are further questions about whether external or selfregulation is more appropriate.

An additional question that our competitiveness analogy may excite is this: Is there not a dark side to competition? ${ }^{11}$ Could not one argue that in addition to the desirable outcomes of competition, there are trivial or socially undesirable consequences, too? To illustrate, there is certainly competition in the clothing industry, but is not one of the effects the oscillating fads and fashions that induce people to spend vast sums each year to replace their now out-of-fashion clothes? ${ }^{12}$ And are not those expenditures socially wasteful? Does competition in the legal-education marketplace

L. 915,972 (1998).

9. For an elaboration, see Thomas S. Ulen, A Nabel Prize in Legal Science: Theory, Empirical Work, and the Scientific Method in the Study of Law, 2002 U. ILL. L. REv. 875, 915-17.

10. Perhaps one way of putting the proposition forcefully is to examine its antithesis-that where there is little or no competition, there is little innovation.

11. We leave to one side the many examples of attempts to stifle competition through cartelization or other anticompetitive actions.

12. We are well aware of the fact that one could make a strong case for the proposition that the oscillating fads and fashions are maximizing consumer well-being - that is, that the clothing industry is simply responding appropriately to a widespread consumer demand for new items and is not, as some would suggest, artificially manipulating consumer wants. 
lead to a truly better understanding of law or to the scholarly equivalent of rising and falling hemlines? ${ }^{13}$

This is a fair question. A reasonable participant in the scholarly enterprise might believe that the welter of scholarly innovations thrown out in a competitive legal academy surely contains the scholarly equivalent of rising and falling hemlines-very few, if any, of those innovations will survive. As a result, she might not invest much in learning about or becoming skilled in these new innovations.

In the commercial marketplace there is a test for deciding which innovations will survive-provider profitability resulting from consumer acceptability. Much of higher education is organized on a non-profit basis, so it is not obvious that the academy has an analogous process for sorting out which innovations should survive and which ought to fade away. Nonetheless, we strongly believe that the academy has an effective and efficient filtering process for distinguishing among those innovations that ought to survive and those that are ephemeral. In Part IV we elaborate on that filtering process and argue that a competitive legal academy not only generates lots of innovations but appropriately chooses among those innovations on the basis of expected usefulness to the ongoing scholarly enterprise.

The upshot of our central proposition is the normative (and, we believe, empirically testable) claim that a competitive legal academy, in which there is an effective and efficient filtering process, will generate socially valuable scholarly innovations.

We intend to illustrate our general theory of the production and adoption of legal scholarly innovations by looking at the economic analysis of law. In order to understand that particular innovation, we need to advance a subsidiary proposition to supplement the central proposition about the importance of competition. Our subsidiary proposition is that a legal academy's receptivity to innovation from contiguous social-scientific disciplines, such as sociology, psychology, economics, and political science, is greater the more thoroughly that academy has opted to pay attention to the law's actual effects in action in evaluating law and the less it focuses exclusively on doctrinal matters. ${ }^{14}$

13. See discussion on "Informational and Reputational Cascades" infra Part IV.J and text accompanying note 268 .

14. We do not contend that this interest in law's actual effects must precede the adoption of every legal scholarly innovation-only that class of innovations that borrows from the other social sciences. It follows that there are other legal scholarly innovations that, under our hypothesis, require only a competitive legal academy as a precondition of production and adoption. To take an illustration, we believe that for scholars to develop an interest in the resonances between literature and the law requires only that there be some competitive return to scholarly innovation. There is, to be clear, no reason to believe that a scholarly interest in law and literature necessitates a prior interest in law's actual behavioral effects. 
Why should there be this necessary condition for the subsequent interest in our exemplary scholar innovation-law and economics? The scholarly concern with law's effects frequently goes under the name of "legal realism." ${ }^{15}$ In the United States legal realism took several forms or had different strands, but two common themes among them were a skepticism of formalism and a concern for the actual effects of law on targeted behavior. ${ }^{16}$ Law and economics, it has been said, is attractive to those who have an interest in law's actual effects because the economic analysis of law is a powerful tool for predicting and evaluating the actual consequences of law on targeted behavior. ${ }^{17}$ If, for instance, tort law becomes interested not just in corrective justice but also in whether exposure to tort liability induces more careful behavior or safer products and, therefore, a reduction in the social costs of accidents, then legal scholars need a technique that articulates the connection between tort liability and precautionary behavior and that provides for measuring the presence, if any, of that behavior. Economics (and other social scientific disciplines) provide both the theoretical account and empirical techniques. ${ }^{18}$ So, in summary, we hypothesize, as our subsidiary proposition to our central proposition about the importance of competition, that a legal realist revolution is a prerequisite, a necessary but not a sufficient, condition for the later reception within the legal academy to law and economics (and other social-scientific innovations).

The empirical implications of our propositions should now be clear. Legal innovations in scholarship will occur where there are competitive returns to being innovative, and if a legal academy is competitive and has evidenced a prior interest in law's actual effects, that academy may adopt the economic analysis of law. These factors should provide us with enough guidance to make sense of the stylized facts that we noted earlier-namely, that many legal scholarship innovations have come from North America, that few have originated elsewhere in the world's legal academies, and that law and economics will be more attractive as a scholarly innovation to North American legal scholars than to legal scholars elsewhere. Although Europe has had legal realists, as in the Swedish school of legal realism, ${ }^{19}$

15. See generally Michael Steven Green, Legal Realism as Theory of Law, 46 WM. \& MARY L. REV. 1915, 1921-39 (2005).

16. See generally NEIL DUXBURY, PATTERNS OF AMERICAN JURISPRUDENCE (1997); JOHN HENRY SCHLEGEL, AMERICAN LEGAL REALISM AND EMPIRICAL SOCIAL SCIENCE (1995).

17. See generally Symposium, Law and Economics and the Rule of Law, 21 HARv. J.L. \& PuB. POL'Y 1 (1997).

18. Economics, psychology, and other social scientific disciplines do not necessarily provide the only theory and empirical methods for pursuing this concern about tort law's actual effects on behavior. We are quite confident that in a competitive legal academy there will be additional innovations in these methods.

19. See generally Göran Skogh, Law and Economics in Sweden, 11 REV. L. \& ECON. 319, 31921 (1991) (describing the Scandinavian version of legal realism). 
and the German National Socialist brand of legal realism ${ }^{20}$ (a connection that Professor Hans-Bernd Schäfer reminds us has made Germans and other Europeans wary of legal realism), ${ }^{21}$ legal scholars in Europe have not fully embraced the let's-look-at-the-effects version of legal realism.

The elaboration of our argument proceeds as follows. In the next part we say what we mean by "legal innovation" and "law and economics." In Part III we try to be more empirical about the differences in the degree to which different national legal academies have adopted law and economics. We then, in Part IV, survey the various reasons (such as variations in the willingness to accept an implicit ideological bias in law and economics) that have been given for differences in the degree to which different legal education systems and different national legal systems have adopted law and economics. We reject almost all of those previously offered reasons but find instead that a competitive legal academy (one in which there are returns to innovation) and a prior legal-realist revolution explain observable differences between North America and much of the rest of the world with respect to innovation generally and the adoption of law and economics particularly. Then in Part V we offer a nontechnical model of the demand for and supply of innovation in legal education and suggest how that model would explain the stylized facts regarding the different rates of adoption of law and economics in North America and Europe. Our concluding part summarizes the argument and speculates on what further investigation, including careful empirical investigation, could shed further light on the issues raised in this Article.

We want to make several important points at the beginning. Although we are both devoted practitioners of law and economics, we do not conceive of this Article as being an advocacy piece for law and economics. Rather, we have a different central focus-namely, why do some legal education systems generate innovative methods of teaching, research, and scholarship about law and others do not? That is, we are not seeking to sound a rallying cry for law and economics or to be self-congratulatory, although we recognize that an unavoidable implication of our hypothesis is that law and economics is correct. Nor do we want to belittle other scholarly innovations, such as critical legal studies, that may not yet have gathered widespread acceptance. Our interest is in identifying a process, one that we firmly believe will continue well beyond today's understandings, that will tell us much, much more about the law than we currently know, and that will help us to understand law's promises and limits beyond what we now believe to be the case. If we understand that process, then there is the strong possibility that those of us in legal education can take steps to

20. See generally INGO MÜLLER, HITLER'S JUSTICE (1991).

21. See infra note 184 and accompanying text. 
create the kind of academy that will generate those further understandings as quickly as possible.

\section{What IS A "LEGAL INNOVATION"? AND WhAT COUNTS AS "LAW AND ECONOMICS"?}

By the term "legal innovation" we mean a scholarly innovation that brings a new technique, a new subject matter area, or the like into the study of either law generally or some area within the study of law. Legal realism might be an example of such an innovation, if one considers that innovation to consist of an emphasis on the actual consequences of the law. ${ }^{22}$ Legal formalism, taken to be a focus on the logical coherence among doctrines and across fields of law, might be another. ${ }^{23}$ The use of literary techniques of analysis and textual deconstruction to examine law might be another ${ }^{24}$ Feminist jurisprudence, ${ }^{25}$ law and philosophy, ${ }^{26}$ law and psychology, ${ }^{27}$ critical legal studies ${ }^{28}$ public choice theory, ${ }^{29}$ critical race theory, ${ }^{30}$ empirical legal studies ${ }^{31}$ law and sociology, ${ }^{32}$ and law and

22. See, e.g., DUXBURY, supra note 16, at 65-66 (recognizing the influence of realism across the broad spectrum of the law); Brian Leiter, American Legal Realism, in THE BLACKWELL GUIDE TO THE PHILOSOPHY OF LAW AND Legal ThEORY 50, 50 (Martin P. Golding \& William A. Edmundson eds., 2005) ("American Legal Realism was the most important indigenous jurisprudential movement in the United States during the twentieth century, having a profound impact not only on American legal education and scholarship, but also on law reform and lawyering."); Green, supra note 15, at 1917-39 (discussing the transformative nature of realist thought to the American legal system). See generally BRIAN LEITER, NATURALIZING JURISPRUDENCE: ESSAYS ON AMERICAN LEGAL REALISM AND NATURALISM IN LEGal Philosophy (2007); SCHLEGEL, supra note 16; Symposium, is It Time for $a$ New Legal Realism?, 2005 WIS. L. REV. 335.

23. See generally Symposium, Formalism Revisited, 66 U. CHI. L. REV. 527 (1999).

24. For examples of these methods, see RICHARD A. POSNER, LAW AND LITERATURE (rev. \& enlarged ed. 1998), 2 LAW AND LITERATURE: CURRENT LEGAL ISSUES (Michael Freeman \& Andrew Lewis eds., 1999), and various articles published in both Law and Literature (published 1989-2001 as Cardozo Studies in Law and Literature) and Yale Journal of Law \& the Humanities.

25. For examples, see JUdith A. BaER, OUR Lives Before the LAw: Constructing a FEMINIST JURISPRUDENCE (1999), FEMINIST JURISPRUdENCE (Patricia Smith ed., 1993), Gillian Hadfield, Feminism, Faimess, and Welfare: An Invitation to Feminist Law and Economics, 1 ANN. REV. L. \& SOC. SCI. 285 (2005), and Ann C. Scales, The Emergence of Feminist Jurisprudence: An Essay, 95 YALE L.J. 1373 (1986).

26. See, e.g., RONALD DWORKIN, LAW'S EMPIRE (1986); RONALD DWORKIN, TAKING RIGHTS SERIOUSLY (1977); H.L.A. HART, THE CONCEPT OF LAW (1961); JOHN RAWLS, A THEORY OF JUSTICE (1971); JoHN RAWLS, JUSTICE AS FAIRNESS: A RESTATEMENT (Erin Kelly ed., 2001); JOHN RAWLS, LECTURES ON THE HISTORY OF MORAL PHILOSOPHY (Barbara Herman ed., 2000).

27. For examples, see various articles published in Law \& Psychology Review and Psychology, Public Policy and Law. For behavioral law and economics, see BEHAVIORAL LAW AND ECONOMICS (Cass. R. Sunstein ed., 2000).

28. See generally Mark Kelman, A Guide to Critical legal Studies (1987); Roberto MANGABEIRA UNGER, THE CRITICAL LEGAL STUDIES MOVEMENT (1986).

29. See generally DANIEL A. FARBER \& PHILIP P. FRICKEY, LAW AND PUBLIC ChOICE (1991).

30. See generally Critical RaCe Theory: The Key Writings That Formed THE MOVEMENT (Kimberlé Crenshaw, Neil Gotanda, Gary Peller \& Kendall Thomas eds., 1995); CrITICAL RaCE THEORY IN EDUCATION (Adrienne D. Dixson \& Celia K. Rousseau eds., 2006).

31. For examples, see various articles in the new Journal of Empirical Legal Studies and the Empirical Legal Studies Blog, http://www.elsblog.org. 
biology ${ }^{33}$ are further examples.$^{34}$ Law and economics is just another example.

We want to draw a narrow boundary around the instances of what we would count as innovative. We do not, for example, mean to include as an example of scholarly innovation a novel interpretation of a particular case, statute, or administrative ruling. A scholar who convincingly shows that the consequences of a particular antitrust holding are not at all what conventional analysis would have predicted has, without doubt, made an important contribution to the corpus of antitrust learning. She has not, however, contributed a legal innovation in the sense in which we intend to use that term. To have done so, she would have had to show that her novel interpretive technique had wide application not just to the particular case on which she has focused but to most or all antitrust holdings past, present, and future. ${ }^{35}$ This suggests that our focus is on broad techniques or styles of analysis and not on narrow claims. So, for example, we would count as innovative a claim that the legal system generally denigrates the interests of women, with an illustration taken from a particular set of family law disputes. But we would not take it as innovative to make the narrow claim that a particular holding in a particular family law dispute showed a disrespect for the women involved. Nor that a particular court had in its series of rulings on family law matters shown a marked disregard for the valid claims of women.

A related topic worth considering is whether it counts as innovative to have defined a new area of legal inquiry. Forty years ago environmental law was a novel area of law; ${ }^{36}$ in the 1940 s civil rights law was all but

32. For examples, see Symposium, Law and Society \& Law and Economics: Common Ground, Irreconcilable Differences, New Directions, 1997 WIS. L. REV. 375, and various articles in Law and Society Review. See generally LAW AND SociologY (Michael Freeman ed., 2006).

33. See, e.g., Owen D. Jones \& Timothy H. Goldsmith, Law and Behavioral Biology, 104 COLUM. L. REV. 405 (2005); Owen D. Jones, Time-Shifted Rationality and the Law of Law's Leverage: Behavioral Economics Meets Behavioral Biology, 95 Nw. U. L. REV. 1141 (2001).

34. We are avoiding the famous concept of a "paradigm" and of a "paradigm shift" from the work of the historian and philosopher of science, Thomas Kuhn. See THOMAS S. KUHN, THE Structure of SCIENTIFIC Revolutions 10-11, 18-19 (3d ed. 1996) (hereinafter KUHN, The STRUCTURE OF SCIENTIFIC REVOLUTIONS]. An example of Kuhnian paradigm shift is that in astronomy from a Ptolemaic - or Earth-centered-notion of our solar system to a Copernican-or heliocentric-notion. Kuhn wrote a classic on that shift, THOMAS S. KUHN, THE COPERNICAN REVOLUTION: PLANETARY ASTRONOMY IN THE DEVELOPMENT OF WESTERN THOUGHT (1957). The reason for avoiding this concept is that we do not want to try to define the prevailing "paradigm" in legal scholarship and, therefore, what it would mean to shift to a new paradigm. We would rather focus on less thorough-going innovations. Some of the innovations that we discuss may purport to be changing the core of legal inquiry, but we need not address that issue. For a discussion of that possibility, see Ulen, supra note 9 , at 909 .

35. The broad innovative aspect may lie latent in the scholar's article, so that another scholar may take that innovation and apply it to a wider-ranging set of issues.

36. See, e.g., Richard J. Lazarus, Restoring What's Environmental About Environmental Law in the Supreme Court, 47 UCLA L. REV. 703, 708 (2000). 
unheard of $;{ }^{37}$ in the 1970 s European Union law was confined to the interpretation of a few treaties and agreements; ${ }^{38}$ twenty years ago no one would have understood what "international intellectual property law" meant; ${ }^{39}$ and "international business transactions" once was absent from law school curricula. ${ }^{40}$ For these and other examples of new areas of the law, should those who organized these new subject-matter areas into coherent bodies of teachable law be recognized as "legal innovators"? Clearly, yes. It is an important aspect of the scholarly craft to be able to recognize (or even to foster) an emerging area of the law and to collect the holdings and commentaries in that area into a coherent body that others can use to instruct themselves and others. ${ }^{41}$

Let us contrast this organization of a new subject-matter area of law with the innovation of applying a new technique to an existing area of law-for example, reconsidering criminal law from a feminist point of view. Both are importantly innovative scholarly work. We recognize that there is a serious question regarding whether these innovations are equal or one is more desirable or important than another. But we want to avoid those questions by simply recognizing both examples as, for our purposes, legal innovations. ${ }^{42}$

We do not want to dwell on these and related points because linedrawing exercises are inherently tedious and almost impossible to resolve conclusively. We leave the matter in this unsatisfactory but, we believe, accurate manner: we are looking at "big" legal innovations, those that change the manner in which we look at the law and the legal system, that alter our perceptions of how the law works or is able to accomplish its ends. In other words, we are defining innovation in "legal methodology," with potential applications in legal practice, but we are not looking at innovations in legal practice per se.

37. See, e.g., The Honorable Nathaniel R. Jones, Senior Circuit Judge, U.S. Court of Appeals for the Seventh Circuit, The Harlan Dissent: The Road Not Taken-An American Tragedy, 18th Henry J. Miller Distinguished Lecture at the Georgia State University College of Law (Mar. 28, 1996), in 12 GA. ST. U. L. REV. 951, 959 (1996).

38. See generally Paul Craig \& GRÁInne de BúrCa, EU law: Text, Cases, and Materials 3-52 (3d ed. 2003).

39. See, e.g., Benjamin R. Kuhn, Comment, A Dilemma in Cyberspace and Beyond: Copyright Law for Intellectual Property Distributed Over the Information Superhighways of Today and Tomorrow, 10 TEMP. INT'L \& COMP. L.J., 171, 179 (1996).

40. See, e.g., Claudio Grossman, Reflections On Being a Law School Dean in an Interconnected World, 31 U. TOL. L. REV. 609, 612 (2000).

41. A prominent example of a legal innovation is the creation of the field of elder law, a creation in which Professor Richard Kaplan of the University of Illinois College of Law was a leading figure. The Honorable Ruth Bader Ginsburg, Remarks at the Rededication Ceremony, University of Illinois College of Law (Sept. 8, 1994), in 1995 U. ILL. L. REV. 11, 14-15.

42. When one of us gave this talk to the Faculty of Law at the University of Ljubljana, Slovenia, Professor and Former Dean Janez Kranjc memorably said, "Legal innovation is not, by definition, law." 
We take law and economics to be a legal innovation within the meaning in which we want to give that term. But before turning to a discussion of what exactly we mean by "law and economics," we want to pause very briefly to distinguish this example of legal innovation from some of those that we have just been discussing. For example, law and economics is not a new field of law in the sense that elder law, ${ }^{43}$ environmental law, ${ }^{44}$ and cyberlaw $^{45}$ are new areas of legal expertise. Strictly speaking, law and economics refers not to a particular field but rather to a methodology or set of tools-the use of, for example, microeconomic theory, econometric empirical techniques, and the like-for investigating legal issues. ${ }^{46}$ Therefore, law and economics is innovative in the same sense in which critical legal studies or critical race theory is innovative-that is, it provides a new method or point of view from which to look at all areas of the law.

We now turn to a consideration of what counts as "law and economics" for the purposes of this Article. There could be several interpretations about "law and economics," and there are different schools of thought. ${ }^{47}$ For our purposes we adopt a definition suggested to us informally by Professor Louis Kaplow: "law and economics" is the application of economic analysis to any area of the law except those areas where its application would be obvious. So, for example, applying this definition, "law and economics" would not include antitrust or competition law, regulated industries, and taxation. But it would include the economic analysis of contract, intellectual property, tort liability, and criminal law.

This definition is not conclusive or precise, and probably not even completely correct. It leaves in limbo such issues as whether securities regulation or the regulation of financial markets or the law of corporate mergers and acquisitions are areas where the application of economic theory is obvious. ${ }^{48}$ And further complicating the use of this definition would be the fact that those whom we might identify as "law and economics" scholars have, in our opinion, made significant contributions to the legal analysis of some of these obvious areas.

43. See generally Lawrence A. Frolik, The Developing Field of Elder Law: A Historical Perspective, 1 ELDER L.J. 1 (1993).

44. See, e.g., Robert W. Adler, The Supreme Court and Ecosystems: Environmental Science in Environmental Law, 27 VT. L. REV. 249 (2003).

45. See, e.g., Peter J. Spiro, Globalization, International Law, and the Academy, 32 N.Y.U. J. INT'L L. \& POL. 567 (2000).

46. ROBERT COOTER \& THOMAS Ulen, LAW AND ECONOMICS 3 (5th ed. 2008).

47. See generally Nicholas Mercuro \& STEVEn G. MEdEMA, Economics and the Law: FROM POSNER TO POSTMODERNISM AND BEYOND (2d ed. 2006) (discussing, among others, "Chicago Law and Economics, ... Public Choice Theory, ... [and] New Haven, Modern Civic Republican and Austrian Approaches").

48. The exclusion of the old "law and economics" is for mere purposes of exposition in the present Article. It does not deny the lengthy history of "law and economics" history that goes back decades. Also, it does not neglect developments post-1960 or so that have brought new methodologies to these "old" parts of "law and economics." 
But these shortcomings notwithstanding, the definition will serve our main purpose. ${ }^{49} \mathrm{We}$ shall identify someone as working in the area of law and economics if he is producing scholarship about and teaching the application of economic analysis to an area of the law in which there is no obvious economic connection.

\section{DIFFERENCES BETWEEN THE UNITED STATES AND EUROPE WITH RESPECT TO THE RECEPTION OF LAW AND ECONOMICS}

Almost everyone who has moved between North America and Europe has the same strong sense that law and economics is vibrant, widespread, and dominant in North American law schools but that it barely exists in European law schools. ${ }^{50,51}$

But law and economics is not the only legal scholarship innovation not widely practiced in Europe: in our opinion, none of the other innovations listed at the beginning of the previous part has had a discernible and profound impact on either the legal academy in European countries or across national boundaries, or on a large number of prominent and productive practitioners.

By contrast, we believe that law and economics has become a prominent and perhaps predominant part of the tool set of the majority of law

\footnotetext{
49. In particular, this definition allows us to exclude from the discussion the recent explosion in Europe of law and economics degrees and programs that usually mean, in our experience, (1) a mere combination of mainstream law with mainstream economics (hence no "law and economics"); or (2) professors teaching standard economics of competition and regulation (now perceived to be influential for European competition law).

50. An important exception worth noting is the Erasmus Master's Program in Law and Economics. See European Master in Law and Economics, http://www.emle.org (last visited Oct. 2, 2007). That Program is a cooperative venture among several European law schools and has recently been ranked among the top five programs in the European Union's Erasmus Mundus competition. See id. (follow "EMLE-Programme: The Programme" link). That competition was not among law programs but among all of the Erasmus programs (more than 150) that chose to submit a proposal. See id. The law and economics program was the only law-related program that was selected for the prestigious award. See id.

It is significant that the Program is cooperative and not centered in a single law school. See id. Nor are there competing law and economics master's programs in Europe and elsewhere of which we are aware. There is only one program, but it is not monopolized by one law school faculty. We are told that many of the participating law schools were extremely skeptical of the worth of the Program until the recent award of the honor and its annual budget of millions of euros. Now the law schools in which the Program is housed have begun to take an interest.

More recently, a subset of the faculties of the Erasmus Master's Program started a European Doctoral Program in Law and Economics. See European Doctorate in Law and Economics, http://edle.economia.unibo.it/ (last visited Oct. 2, 2007).

51. There is a European Association of Law and Economics that, to our knowledge, has held more than twenty annual conferences. See generally European Association of Law and Economics, http://nts4.oec.uni-osnabrueck.de/eale/index.html (last visited Oct. 2, 2007). Incidentally, we know of regional law and economics professional associations in Canada, Australia, Greece, Scandinavia, Finland, Italy, Germany, Spain, Korea, Japan, Latin America, the Caribbean, Asia, and Israel. See Australian Law \& Economics Association Homepage, http://law.anu.edu.au/cle/austlea/ (follow "Links to other sites" hyperlink) (last visited Oct. 2, 2007).
} 
professors in the United States, regardless of their field of professional specialization. We can offer several pieces of empirical evidence to support this belief. The first is a very preliminary comparative measure of the impact of law and economics in the legal scholarship of the United States and Europe. We examined two leading U.S. law reviews-the Harvard Law Review and the Yale Law Journal-and one leading U.K. law review-the Oxford Journal of Legal Studies-to see what percentage of articles in those journals mentioned various central law-and-economics terms over various time periods. Our search was across all articles, notes, essays, comments, and other writings published in the journals during the month of June for the period 1996 to 2005. (For the two U.S. law reviews we also measured the percentage of writings for the time period 1982 to 2005 in order to see if, over the time period covered, there had been a change in the number of writings in those journals using some core lawand-economics terms.) We counted the percentage of writings for each period that contained any of the following words: "economics," "costs," "efficiency," "law and economics," or "Coase." A writing that contained fifteen references to Coase received the same weight as one that contained a single reference. We did not distinguish between favorable and unfavorable references to any of those words. The use of the Oxford Journal of Legal Studies as a proxy for all European law journals is, of course, problematic. But, if anything, we believe that that journal is far more likely than continental law reviews to publish interdisciplinary articles on legal topics. As a result, we consider the findings from the Oxford Journal to be an upper-bound estimate of the use of law and economics in European scholarship.

\begin{tabular}{|c|c|c|c|c|c|}
\hline & $\begin{array}{l}\text { Oxford J. } \\
\text { Legal } \\
\text { Stud. } \\
\text { 1996-2005 } \\
\text { (June) }\end{array}$ & $\begin{array}{l}\text { Yale } \\
\text { L.J. } \\
1996- \\
2005 \\
\text { (June) }\end{array}$ & $\begin{array}{l}\text { Yale } \\
\text { L.J. } \\
1982- \\
2005 \\
\text { (June) }\end{array}$ & $\begin{array}{l}\text { Harv. } \\
\text { L. Rev. } \\
1996- \\
2005 \\
\text { (June) }\end{array}$ & $\begin{array}{l}\text { Harv. } \\
\text { L. } \\
\text { Rev. } \\
\text { 1982- } \\
\text { 2005 } \\
\text { (June) }\end{array}$ \\
\hline Economics & $48.1 \%$ & $63.8 \%$ & $67 \%$ & $68.9 \%$ & $65.9 \%$ \\
\hline Costs & $34 \%$ & $61.9 \%$ & $64.5 \%$ & $73.7 \%$ & $64.4 \%$ \\
\hline Efficiency & $3 \%$ & $36.5 \%$ & $35.6 \%$ & $32 \%$ & $29.7 \%$ \\
\hline
\end{tabular}




\begin{tabular}{|l|l|l|l|l|l|}
\hline $\begin{array}{l}\text { Law and } \\
\text { Economics }\end{array}$ & $\mathbf{7 . 2 \%}$ & $\mathbf{2 1 . 2 \%}$ & $19.1 \%$ & $\mathbf{1 4 . 9 \%}$ & $13.6 \%$ \\
\hline Coase & $\mathbf{2 . 1 \%}$ & $\mathbf{8 . 5 \%}$ & $7.8 \%$ & $3.3 \%$ & $3.8 \%$ \\
\hline Total & $\mathbf{3 3 5}$ & $\mathbf{6 3 6}$ & 1601 & $\mathbf{8 7 4}$ & 2044 \\
Articles & & & & & \\
\hline
\end{tabular}

Table 1: Percentage of Documents with Selected Words Anywhere in the Text

The clear result of this relatively crude measure is that writings in the U.S. journals are much more likely to contain law-and-economics terms than are those in the leading interdisciplinary law journal in the United Kingdom (and Europe). Note in particular the large difference between United States and European legal scholars in the prevalence of the term "efficiency."

More information on the relative importance of law and economics in different parts of the world comes from the work of Professor Oren GazalAyal. ${ }^{52}$ Gazal-Ayal observes that there is a significant difference in the attention paid to law and economics in different parts of the academic world and hypothesizes that these differences are attributable to differences in academic incentives in the different academic systems. ${ }^{53} \mathrm{He}$ reports a number of different comparative measures of the influence of law and economics in different national academies. ${ }^{54}$ For our purposes, we will focus on two different tables.

The first compares the number of articles published in law-andeconomics journals during 2003, 2004, and 2005 by scholars from the United States, Canada, Israel, Europe (the EU member states "before the 2004 enlargement, plus Switzerland and Norway"), and all other nations. ${ }^{55}$

52. See Oren Gazal-Ayal, Economic Analysis of Law and Economics, 35 CAP. U. L. REV. 787 (2007). See also Oren Gazal-Ayal, Economic Analysis of Law in North America, Europe, and Israel, 3 REVIEW OF LAW AND ECONOMICS art. 11 (2007), available at http://www.bepress.com/rle/vol3/iss2/art11/.

53. See id. at 788 ("Hence, one would guess that, if incentives matter to legal scholars, authorship of [law \& economics] papers is likely to be high in Israel, low in Europe, and somewhere in the middle in the United States and Canada.").

54. See id. at 793-97.

55. See id. at 794 . 
The participants are recorded according to whether their principal training was in economics, law, or some other discipline. ${ }^{56}$

\begin{tabular}{||l|l|l|l|l|l|l|l||}
\hline & & \multicolumn{2}{|l|}{$\begin{array}{l}\text { Number } \\
\text { participants }\end{array}$} & \multicolumn{3}{|l||}{ Per 10m people } \\
& & Law & Econ & Neither & Law & Econ & $\begin{array}{l}\text { Nei- } \\
\text { ther }\end{array}$ \\
\hline Population & & & & & & & \\
\hline $299,093,237$ & U.S.A & 94 & 270 & 18 & 3.14 & 9.03 & 0.60 \\
\hline $32,251,238$ & Canada & 5 & 21 & 1 & 1.86 & 6.51 & 0.31 \\
\hline $7,109,929$ & Israel & 22 & 13 & 0 & 30.94 & 18.28 & 0.00 \\
\hline $400,369,441$ & Europe & 32 & 204 & 9 & 0.80 & 5.10 & 0.22 \\
\hline & Other & 8 & 63 & 0 & & & \\
\hline
\end{tabular}

Table 2: Comparative Publication in Law and Economics Journals by Scholars with Different Formal Training ${ }^{57}$

The main lesson to be gleaned from this table is that participation in writing for law and economics journals is, in all countries but Israel, far more common among economists than among lawyers. Professor GazalAyal further notes that the participation rate among economists is about the same, per capita, in the United States, Canada, and Europe.$^{58}$ Finally, for the points made in this paper, one should recognize that the participation rate of lawyers is both absolute and relative to total population about the same in the United States and Canada, and that that rate is about three times the rate of participation of European lawyers. ${ }^{59}$

Professor Gazal-Ayal also measured the participation in publications in law-and-economics journals by lawyers and economists by country in 2003,2004 , and 2005 not according to whether the writer's first degree was in economics or in law but according to whether their current aca-

56. See id. at 795 \& n.34. (Gazal-Ayal counts writers of articles as being "law" if they teach in a law school or have degrees in both law and economics, even if their highest degree is in economics and as an "economist" if they teach in an economics faculty, even if their degree is in law.).

57. See id. at 794 .

58. See id. at 795 .

59. See id. 
demic affiliation was in an economics or a law faculty or neither ${ }^{60}$ Here are his results:

\begin{tabular}{||l|l|l|l|l|l|l|l||}
\hline \hline & & \multicolumn{2}{|l|}{$\begin{array}{l}\text { Number } \\
\text { participants }\end{array}$} & \multicolumn{3}{|l||}{ Per 10m people } \\
\hline Population & & Law & Econ & Neither & Law & Econ & Nei- \\
& & & & & & & ther \\
\hline $299,093,237$ & U.S.A. & 114 & 306 & 19 & 3.81 & 10.23 & 0.64 \\
\hline $32,251,238$ & Canada & 4 & 18 & 0 & 1.24 & 5.58 & 0.00 \\
\hline $7,109,929$ & Israel & 10 & 10 & 1 & 14.06 & 14.06 & 1.41 \\
\hline $400,369,441$ & Europe & 32 & 201 & 7 & 0.80 & 5.02 & 0.17 \\
\hline & Other & 2 & 36 & 1 & & & \\
\hline
\end{tabular}

Table 3: Comparative Publication in Law and Economics Journals by Faculty Members in Economics and in Law Departments ${ }^{61}$

Here the picture portrayed is slightly different from that of Table 2 . The share of the U.S. law schools changes significantly and those shares of the law faculties in other countries declines. The principal reason for this change is, as we shall argue later, that many non-American law-andeconomics scholars are affiliated with U.S. law schools rather than with law or economics faculties in their home countries. ${ }^{62}$

Now turning to the state of law and economics in the United States, we can offer some collateral evidence on the impact of law and economics in the form of a table showing the increase in law and economics law professors in U.S. law schools in a recent ten-year period. The table comes from Judge Richard Posner and was meant not to indicate the prominence of law and economics in the U.S. legal academy but rather the increasing receptivity to the social sciences in law school hiring. ${ }^{63}$

\footnotetext{
60. See id. at 796.

61. See id.

62. See infra note 156; infra note 111 and accompanying text.

63. See Richard A. POSNER, CATASTROPHE: RISK AND ReSPONSE 204-06 (2004). The text says that the table

reports the number of law teachers in different fields today and a decade ago as recorded by the Association of American Law Schools (AALS). . . . The rapid growth of 'law and economics' attests to the increasing receptivity of law to the social sciences but is not matched by increased receptivity to the
} 


\begin{tabular}{||l|l|l|l|l||}
\hline & $1992-93$ & $2002-03$ & Difference & $\begin{array}{l}\text { Percentage } \\
\text { increase }\end{array}$ \\
\hline Jurisprudence & 658 & 808 & 150 & $22.80 \%$ \\
\hline Law and economics & 123 & 209 & 86 & $69.92 \%$ \\
\hline Law and science & 107 & 136 & 29 & $27.10 \%$ \\
\hline Constitutional law & 1452 & 1679 & 227 & $15.63 \%$ \\
\hline
\end{tabular}

Table 4: Size of Fields of Academic Law, 1992-1993 and 2002$2003^{64}$

There are, we believe, two noteworthy points illustrated in the table. First, law professors self-identified as being in law and economics have shown far and away the greatest rate of growth in the period 1992-2002 of any of the fields considered. Second, we believe that as revealing as the figure is, it significantly understates the impact and importance of law and economics on the U.S. legal academy. We believe that this understatement arises from the fact that there are many professors who routinely use or at least fully understand and value law and economics who would not classify themselves as specialists in law and economics for The AALS Directory of Law Teachers. ${ }^{65}$ For example, at the University of Illinois College of Law the most recent Directory identifies only five people at Illinois as being in the field of law and economics. ${ }^{66}$ In point of fact, we estimate that at least seven people currently on the faculty could teach a full course in the economic analysis of law with little preparation ${ }^{67}$ and another two could teach such a course with moderate preparation. ${ }^{68}$ And that counts only a teaching commitment to law and economics. It is our sense that the majority of the

physical sciences.

Id. at 204, 206.

64. Id. at 206.

65. See, e.g., ASS'N OF AM. LAW SCHOOLS, THE AALS DIRECTORY OF LAW TEACHERS: 20052006 (2005).

66. See id. at 1305-07.

67. Amitai Aviram, Lee Fennell, Jay Kesan, Richard H. McAdams, Andrew Morriss, Larry Ribstein, and Thomas S. Ulen. Two of those faculty members-Lee Fennell and Richard McAdamsare now at the University of Chicago Law School, but Nuno Garoupa has joined the University of Illinois College of Law faculty.

68. Tom Ginsburg and David Hyman. 
Illinois faculty understands and makes law-and-economics arguments in their written work.

Another highly suggestive bit of collateral evidence regarding the influence of law and economics in U.S. law schools is the dramatic increase in the number of $\mathrm{Ph} . \mathrm{D} . / \mathrm{J} . \mathrm{D}$. degree holders who have joined law school faculties in the last several decades. For example, the Associate Dean for Faculty and Research at Boalt Hall reported to us that twenty percent of that school's faculty has a Ph.D. in economics, ${ }^{69}$ and a recent Appointments Committee chair at the University of Pennsylvania Law School reported to us that there are seven economics Ph.D.s on that distinguished school's faculty. ${ }^{70}$ Professor Larry Solum's Legal Theory Blog annually reports information on entry-level hires in U.S. law schools. ${ }^{71}$ A recent compilation reported that nearly $50 \%$ of entry-level hires for the 20052006 academic year had an advanced degree (such as a Ph.D.) in addition to a J.D. ${ }^{72}$

Finally, in late 2005 the magazine Legal Affairs sought to identify "Who Are the Top 20 Legal Thinkers in America?"73 They polled their readers in their January | February issue and reported the results on their website. ${ }^{74}$ They divided the legal thinkers into three groups-academics, judges, and commentators. ${ }^{75}$ Of the eight academics, three (Richard Epstein, Lawrence Lessig, and Cass R. Sunstein) have produced important law-and-economics scholarship. ${ }^{76}$ Of the eight judges, two (Frank Easterbrook and Richard Posner) are prominent law-and-economics scholars, ${ }^{77}$ and another two (Alex Kozinski and Antonin Scalia) know law and economics and have produced scholarship that uses its insights. ${ }^{78}$

So much for the impact of law and economics in the United States. What evidence can we point to regarding the lack of a presence in Europe and elsewhere?

Consider, for example, that there is, to our knowledge, only one economist with a full-time appointment in a German law school-the dis-

69. Private conversation with Professor Andrew Guzman.

70. Private conversation with Professor Ed Rock.

71. See Legal Theory Blog, Entry Level Hiring Report, http://solum.typepad.com/legaltheory/entry_level_hiring_report/index.html (last visited Oct. 14, 2007).

72. See Legal Theory Blog, 2005 Entry Level Hiring, Interim Report, http://lsolum.blogspot.com/2005_04_01_lsolum_archive.html\#111318173249256399 (last visited Oct. 2, 2007).

73. See Legal Affairs-Who Are the Top 20 Legal Thinkers in America?, http://legalaffairs.org/poll (last visited Oct. 2, 2007).

74. See id.

75. See id.

76. See, e.g., RICHARD A. EPSTEIN, TAKINGS (1985); CASS R. SUnSTEIN, THE COST-BENEFIT STATE (2002); Lawrence Lessig, Coase's First Question, REgulation, Fall 2004, at 38.

77. See Gazal-Ayal, supra note 52, at 793-94.

78. See, e.g., Alex Kozinski, The Toyota Principle, 56 WASH. \& LEE. L. REV. 923 (1999); Antonin Scalia, The Role of the Judiciary in Deregulation, 55 ANTTTRUST L.J. 191 (1986). 
tinguished scholar Hans-Bernd Schäfer of the University of Hamburg. ${ }^{79}$ There is not a single chair in law and economics in Germany. ${ }^{80}$ There is a European Journal of Law and Economics, but it is not sponsored and staffed (as are U.S. law journals) by a particular European law school or university. ${ }^{81}$ Very few European law schools have a law-and-economics working paper series at the Social Science Research Network, whereas almost twenty law schools in the United States have such a series. ${ }^{82}$ To our knowledge, in the United Kingdom, which will later assume a central role in our search for explanations for the differences between the United States and Europe, there are very few, if any, endowed professorships in law held by a scholar in law and economics and only one person-Timothy Swanson of University College, London-with a chair in law and economics. ${ }^{83}$ More recently, in June 2007, John Armour was appointed to a chair in law and finance at the University of Oxford. ${ }^{84}$ And, finally, while it is virtually impossible to have a substantive discussion about a legal matter in the United States without having input from law and economics, it is almost impossible for law and economics to become part of any substantial discussion of law within any nation in the European Union. ${ }^{85}$

Another anecdotal but significant indication that law and economics has not influenced U.K. legal scholarship can be seen in the recent The

79. To our knowledge there is no economist appointed to a law school as resident faculty in France, Belgium, Switzerland, Spain, Portugal, or Italy, and only two in the United Kingdom: Frank Stephen in Manchester and Morten Hviid in East Anglia. One of the authors of this paper, Nuno Garoupa, has a twenty percent appointment in Manchester. There are some distinguished lawyers who do law and economics on faculties in the United Kingdom: Anthony Ogus at the University of Manchester, see, e.g., Nuno Garoupa \& Anthony Ogus, A Strategic Interpretation of Legal Transplants, 35 J. Legal STUd. 339 (2006), Brian Cheffins at the University of Cambridge, see, e.g., Brian R. Cheffins, Does Law Matter? The Separation of Ownership and Control in the United Kingdom, $30 \mathrm{~J}$. LEGAL STUD. 459 (2001), John Armour at the University of Oxford, see, e.g., John Armour \& Michael J. Whincop, The Proprietary Foundations of Corporate Law, 27 OXFORD J. LEGAL STUD. 429 (2007), and Timothy Swanson at the University College, London, see, e.g., Timothy Swanson \& Robin Mason, Nonbargaining in the Shadow of the Law, 18 INT'L REV. L. \& ECON. 121 (1998).

80. The academic terms "chair," "professor," "lecturer," "faculty line," and the like do not have consistent meanings across borders. For example, a European "chair" which usually includes special privileges for the faculty member, is not equivalent to a U.S. "chair," which is a particular form of endowed professorship, usually the result of a substantial gift to the university.

81. See generally issues of the European Journal of Law and Economics, available at http:/www.springer.com/west/home/economics/law + \& + economics?SGWID =4-40551-70$35503377-0$.

82. See Social Science Research Network List of Research Paper Series, http://www.ssm.com (follow "Research Paper Series" hyperlink) (last visited Oct. 2, 2007).

83. See Faculty Profile of http://www.econ.ucl.ac.uk/displayProfile.php?staff_key $=30$ (last visited Oct. 14, 2007) ("Tim Swanson holds the Chair in Law \& Economics at UCL, ").

84. University of Oxford, Oxford Appoints First Lovells Professor of Law and Finance, http://www.admin.ox.ac.uk/po/070315.shtml (last visited Oct. 14, 2007).

85. We want to distinguish very carefully between the lack of law and economics input in national legal discussions in Europe and the increasing importance of law and economics input in European Union legal discussions. We elaborate on this distinction in Part V below. 
Oxford Handbook of Legal Studies ${ }^{86}$ There are more than forty chapters in the Handbook surveying substantive areas of the law, the legal academy, and the legal profession with a focus on the United Kingdom. ${ }^{87}$ Even though there are chapters on regulation, ${ }^{88}$ corporations, ${ }^{89}$ competition, ${ }^{90}$ labor,${ }^{91}$ intellectual property, ${ }^{92}$ environmental law, ${ }^{93}$ the history of legal studies, ${ }^{94}$ and the role of academics in the legal system, ${ }^{95}$ there is no reference to standard law and economics insights. Nor is there any mention of law and economics in the chapters on contract, ${ }^{96}$ tort, ${ }^{97}$ property, ${ }^{98}$ or criminal law ${ }^{99}$-all of which are areas that have been significantly affected by the economic analysis of law. It is inconceivable that a Handbook written on exactly the same topics with a focus on the United States would not contain literally hundreds of law-and-economics insights and references.

Contrast this paucity of law and economics in this particular Oxford handbook with another, The Oxford Handbook of Jurisprudence and Philosophy of Law. ${ }^{100}$ In contrast to the Handbook of Legal Studies, that of jurisprudence and philosophy was written largely by Americans. ${ }^{101}$ The chapter on the philosophy of private law lists "[1]aw and [e]conomics [a]pproaches" as among the "[l]eading [t]heoretical [m]odels of [p]rivate [1]aw." ${ }^{102}$ Other chapters cite or quote the work of law-and-economics scholars such as Richard Posner, Steven Shavell, and Ronald Coase. ${ }^{103}$

86. THE OXFORd HANDBOOK OF LEGAL STUDIES (Peter Cane \& Mark Tushnet eds., 2003).

87. See id. at v-vii.

88. See Christine Parker \& John Braithwaite, Regulation, in THE OXford HANDBOOK OF LEgAL STUDIES, supra note 86 , at $119,119-45$.

89. See Brian R. Cheffins, Corporations, in The OXford HANDBooK of Legal STudies, supra note 86 , at $485,485-509$.

90. See David J. Gerber, Competition, in THE OXFORD HANDBOOK OF LEGAL STUdies, supra note 86 , at $510,510-35$.

91. See Mark Barenberg, Workers, in THE OXFORD HANDBOOK OF LEGAL STUDIES, supra note 86 , at $563,563-92$.

92. See Wendy J. Gordon, Intellectual Property, in THE OXFord HANDBook of LEgAL STUDIES, supra note 86 , at $617,617-46$.

93. See Lisa Heinzerling, The Environment, in THE OXFORD HANDBOOK OF LEGAL STUdIES, supra note 86 , at $701,701-26$.

94. See Neil Duxbury, A Century of Legal Studies, in THE OxFORD HANDBoOK OF LEGAL STUDIES, supra note 86 , at $950,950-74$.

95. See William Twining et al., The Role of Academics in the Legal System, in THE OXFORD HANDBOOK OF LEGAL STUDIES, supra note 86 , at 920, 920-49.

96. See James Gordley, Contract, in THE OXFORD HANDBOOK OF LEGAL STUDIES, supra note 86, at 3, 3-20.

97. See John C.P. Goldberg, Ton, in THE OXFORd HANDBOOK OF LEGAL STUDIEs, supra note 86 , at $21,21-47$.

98. See Michael A. Heller, Property, in THE OXFORD HANDBOOK OF LEGAL STUDIES, supra note 86 , at $62,62-79$.

99. See Jeremy Horder, Criminal Law, in THE OXFORD HANDBOOK OF LEGAL STUdiEs, supra note 86 , at $226,226-49$.

100. THE OXFORd HANDBOOK OF JURISPRUDENCE AND PhILOSOPHY OF LAW (Jules Coleman \& Scott Shapiro eds., 2002).

101. See id. at ix-x.

102. See Benjamin C. Zipursky, Philosophy of Privale Law, in THE OXFORD HandBOOK OF 
We do not want to leave the impression that the problem is one peculiar to law and economics. It is, rather, a pervasive failure to recognize any scholarly innovation from outside law as worthwhile. For example, in an entry in the The Oxford Handbook of Legal Studies on the welfare state, Nick Wikeley remarks that neither critical legal studies nor more leftist approaches have been very influential in Europe. ${ }^{104} \mathrm{He}$ complains that although there is excellent progress in modern legal scholarship of the welfare state, few British law schools have taken that scholarship seriously. ${ }^{105}$ Researchers active in these fields, he says, "could comfortably fit into a small seminar room." 106

We must draw attention to two important exceptions to our assertion that law and economics has little presence in Europe. The first is the Netherlands, a nation that has long prided itself on its innovative practices in a wide variety of fields. ${ }^{107}$ There are nine law schools in the Netherlands, and because of the relatively small size of the country, students from anywhere in the country can attend any one of those schools. ${ }^{108}$ There should be, therefore, competition among the schools to attract students. As a result of that competition, as well as the country's long tradition of innovation in many areas of human endeavor, "[a]ll law faculties now regularly focus on the economic implications of . . . legal rules." 109 That is a startling departure from the European norm. ${ }^{110}$

JURISPRUDENCE AND PHILOSOPHY OF LAW, supra note 100, at 624 .

103. See John Finnis, Natural Law: The Classical Tradition, in THE OXFORD HANDBOOK OF JURISPRUDENCE AND PHILOSOPHY OF LAW, supra note 100, at 1, 32; Christopher Kutz, Responsibility, in THE OXFORD HANDBOOK OF JURISPRUDENCE AND PHILOSOPHY OF LAW, supra note 100, at 548, 581 n.94, 583, 585; Benjamin Zipursky, Philosophy of Private Law, in THE OXFORD HANDBOOK OF JURISPRUDENCE AND PHILOSOPHY OF LAW, supra note 100, at 623, 623-25.

104. See Nick Wikeley, The Welfare State, in THE OXFORD HANDBOOK OF LEGAL STUDIES, supra note 86, at 397, 402-04. Interestingly in this respect, we should mention the socio-legal studies in the United Kingdom, a movement that started at the Oxford Centre for Socio-Legal Studies in the 1970s where, for example, Professor Anthony Ogus started his career. See generally Oxford Centre for Socio-Legal Studies Homepage, http://www.csls.ox.ac.uk/ (last visited Oct. 2, 2007). Although this movement has been steadily increasing, as more international doctoral students conduct research in law from a policy perspective, it has never achieved the influence that law and economics has in the United States. See Mauricio García-Villegas, Comparative Sociology of Law: Legal Fields, Legal Scholarships, and Social Sciences in Europe and the United States, 31 L. \& Soc. INQUIRY 343, 362-63 (2006).

105. See Wikeley, supra note 98 , at 411 .

106. See id.

107. See supra note 8 and accompanying text.

108. René de Groot, Recruitment of Minds: Selecting Professors in the Netherlands, 41 AM. J. COM. L. 441, 444 (1993).

109. Rudi W. Holzhauer \& Rob Teijl, Law and Economics in the Netherlands, in 1 ENCYCLOPEDIA OF LAW AND ECONOMICS 274, 275 (Boudewijn Bouckaert \& Gerrit De Geest eds., 2000), available at http://encyclo. findlaw.com/0355book.pdf.

110. The case of the Netherlands certainly contrasts dramatically with the situation in Belgium. In Belgium, only the University of Ghent has a thriving law and economics presence among its faculty that we know of (Boudwijn Bouckaert, Gerrit De Geest, and Ben Depoorter; although De Geest and Depoorter now hold appointments at the University of Washington in St. Louis and the University of Miami law schools respectively). Former Dean Guy Horsmans of Université Catholique de Louvain 
Another departure is the practice in Israel. The legal academy in that country is international in its aspirations and activities, with a particular focus on staying in touch with and emulating the United States' law schools. ${ }^{111}$ Legal academics seek to publish in U.S. law journals, and many of the brightest young talents in Israeli law schools have taken temporary or permanent positions on U.S. law school faculties. ${ }^{12}$

A final point that bears making is that the differences we note between Europe and the United States with respect to legal innovations, particularly law and economics, do not seem to be a generalizable problem in the sense that they attend all other disciplines within the academy, aside from law. European and U.S. medical schools seem to be teaching the same topics and techniques. Although we cannot be certain of this, we strongly suspect that such differences as exist between U.S. and European medical schools may have to do with resources available to try new technologies and some predictable differences between the health care delivery systems. Similarly, we do not perceive a significant difference between the receptivity to innovative scholarship in European and U.S. business schools. Nor is there an obvious difference between United States and Europe with respect to innovations in other social sciences such as anthropology, economics, physics, psychology, political science, public administration and public policy, sociology, and the like. If there is a difference in receptivity to innovation between the European and U.S. academies, it appears to be particularly significant in the study of law.

\section{SOME POSSIBLE REASONS FOR THESE DIFFERENCES}

If our description of the differences between the reception of law and economics in the United States and Europe is accurate and is representative of the differences in receptivity in the United States and Europe to other legal scholarly innovations, then the central question is, "Why should there be these differences in receptivity to scholarly innovations?" We are not the first ones to remark on this difference, and there have already been numerous attempts to explain why law and economics has been

(Louvain-la-Neuve) tried unsuccessfully to introduce law and economics into his Faculty of Law. And the Faculty of Law of the Katholieke Universiteit Leuven appears to have remained impervious to law and economics.

111. Cf. Basheva E. Genut, Competing Visions of the Jewish State: Promoting and Protecting Freedom of Religion in Israel, 19 FORDHAM INT'L L.J. 2120, 2120 (1996) (noting that "Israel has emulated U.S. . . . legal principles and adopted them as its own").

112. The programs for the 2005 and 2006 Annual Conferences of the American Law and Economics Association showed that ten percent of those presenting papers at the conference have some affiliation with an Israeli law school. See Am. Law \& Econ. Ass'n, Fifteenth Anmual Meeting Program (May 6-7, 2005), available at http://www.amlecon.org/2005_Program.pdf (last visited Oct. 2, 2007); Am. Law \& Econ. Ass'n, 16 ${ }^{\text {th }}$ Annual Meeting Program (May 5-6, 2006), http://www.amlecon.org/2006_program.pdf (last visited Oct. 2, 2007). 
so successful in the United States and Canada and not nearly so successful in other countries. ${ }^{113}$

Our purpose in this part of the Article is to articulate and evaluate the various explanations that have been offered for these important differences. As will become evident, we find most of these explanations to be unpersuasive. This conclusion will go much against the prevailing wind of explanation, which holds, for example, that law and economics is a particular product of the common law systems ${ }^{114}$ or is particularly attractive to those countries that espouse a vibrant liberal (in the nineteenth-century sense) political ideology. ${ }^{115}$

To foreshadow our conclusions, we find that the most important factors in explaining the production and adoption of legal innovations is the degree of competitiveness in a nation's higher education sector and, with respect to law and economics, whether the nation's legal educators have had a prior innovation that approximates legal realism. ${ }^{116}$

\section{A. Political Ideology}

One common explanation for the difference between Europe and the United States in receptivity to scholarly innovations has to do with a perceived difference in the prevailing political ideologies generally and, specifically, within the legal academies of the two regions: the United States is said to be far friendlier toward free-market, classic liberalism than is Europe ${ }^{117}$ and the legal academy in the United States is thought to be far more receptive to classical liberal arguments than is the European legal academy. ${ }^{118}$ Insofar as law and economics is perceived to be a legal version of free-market or Chicago school economics, then its warm reception in the United States and cold shoulder treatment in Europe are only reflections of differences in dominant ideologies in the two regions. ${ }^{119,}{ }^{120}$ So, if

113. See, e.g., Kenneth G. Dau-Schmidt \& Carmen L. Brun, Lost in Translation: The Economic Analysis of Law in the United States and Europe, 44 Colum. J. TranSNAT'L L. 602 (2006).

114. See Richard A. Posner, Law and Economics in Common-Law, Civil-Law, and Developing Nations, 17 RATIO JURIS 66, 68 (2004).

115. See, e.g., Dau-Schmidt \& Brun, supra note 113, at 605-06.

116. Some commentators on earlier drafts have suggested to us that even if we are right to contend that none of the factors we cite is important (or singularly important) in explaining the attraction of law and economics, all of the factors taken together may have an explanatory force that each of them or any subgrouping of them might not have. We do not find this "whole being greater than the sum of its parts" explanation plausible.

117. See, e.g., Robert A. Kagan, Adversarial Legalism: The AMERICAN Way of LAW 3-17 (2001).

118. See, e.g., Jonathan Zasloff, Law and the Shaping of American Foreign Policy: The Twenty Years' Crisis, 77 S. CAL. L. REV. 583, 674 (2004); Nomi Maya Stolzenberg, A Book of Laughter and Forgetting: Kalman's "Strange Career" and the Marketing of Civic Republicanism, 111 HARV. L. REV. 1025, 1025-26 (1998) (reviewing Laura Kalman, The Strange Career of Legal LIBERALISM (1996)).

119. There are other variations on this theme, such as that the differences in receptivity to law and 
the prevailing political ideology in U.S. law schools is politically conservative and an academic method of examining law appears that seems to be conservative, then it is adopted in U.S. law schools. By contrast, if European law schools are principally politically leftist, then they have rejected law and economics because it strikes them as antithetical to their core ideological values. ${ }^{121}$

There are three principal problems with this explanation. First, U.S. law schools tend not to be politically conservative but to be left-ofcenter. ${ }^{122}$ Of course, one could argue that there are certain U.S. law

economics reflect underlying legal cultural differences or predilections for utilitarianism versus Kantianism. We deal with these variants later in this part. See infra Subpart IV.F.

120. The hijacking of law and economics by Chicago-oriented scholars has been discussed by several scholars in Symposium, Calabresi's The Costs of Accidents: A Generation of Impact on Law and Scholarship, 64 MD. L. REV. 1 (2005). In particular, Anita Bernstein, Whatever Happened to Law and Economics?, 64 MD. L. REv. 303 (2005), Adam Benforado \& Jon Hanson, The Costs of Dispositionism: The Premature Demise of Situationist Law and Economics, 64 MD. L. REv. 24 (2005), and Ugo Mattei, The Rise and Fall of Law and Economics: An Essay for Judge Guido Calabresi, 64 MD. L. REV. 220 (2005), all discuss this phenomenon.

121. For example, Louis Vogel, in Foreword to ANTHONY Ogus \& Michael Faure, Économie DU DROIT: LE CAS FRANÇAIS 5, 5-6 (2002), argues that law and economics is an American byproduct because the French tradition is interventionist and egalitarian as opposed to the liberal (in the European sense) tradition of America. He further argues that law and economics faces a difficult task with respect to French law due to the coherence of the code system and the hierarchy of judges for whom efficiency is not a supreme value. Professor Vogel argues that the slow growth of law and economics in France is due to the cultural and ideological contrast between the European and the American perceptions of law and society.

Another French scholar, Christophe Jamin, has identified-in Economique et Droit, in DictionNAIRE DE LA CUlture JURIDIQue 578-81 (Denis Allond \& Stéphane Rials eds., 2003)-the following reasons why law and economics has not caught on in France: (1) economics is an auxiliary science of law since economics emerged from the study of law; the fields therefore have the same difficult relationship that many fathers and sons have; (2) where the United States engaged in a legal realist revolution, France followed an "economic law" revolution, which had a Marxist foundation, arguing that law was dictated by the economic realities of a society; (3) most French legal scholars are deliberately ignorant of law and economics, viewing it as a Trojan horse for neoliberalism and an Anglo-American worldview; (4) French law and economics scholars tend to use American examples and American-oriented policy issues to illustrate their points, and these examples and issues do not appeal to most French legal scholars; (5) law and economics represents an attack on French legal culture and tradition; and (6) law and economics will grow in France only when the process of denationalization (décivilisation) of French (and other) law happens through more intense globalization.

122. In Thomas S. Ulen, A Crowded House: Socioeconomics (and Other) Additions to the Law School and Law and Economics Curricula, 41 SAN DIEGo L. REv. 35, 43 \& n.15 (2004), there is a citation to a study performed by "Professor James Lindgren of the Northwestern University School of Law [regarding the] political beliefs" of a group of law and economics scholars. Lindgren "administered a portion of the General Social Survey" (GSS) to a group attending the Midwest Law and Economics Association (MLEA) Annual Meeting and reported on the results of the survey the following day. Id. For the entire U.S. population, the median score on the GSS is approximately 45 , with 0 being perfectly conservative and 100 being perfectly liberal. Id. The median score for the MLEA group was 73, far more liberal than the general population, but less liberal, we suspect, than law faculty generally. See id. For more on the GSS, see Inter-University Consortium for Political and Social Research General Social Survey Series, http://webapp.icpsr.umich.edu/cocoon/ICPSRSERIES/00028.xml (last visited Oct. 3, 2007).

A recent article in The New York Times reported that a survey of university faculty in the United States found "that Democratic professors outnumber Republicans by at least seven to one in the humanities and social sciences." John Tierney, Republicans Ounumbered in Academia, Studies Find, N.Y. 
school faculties that are conservative, such as those, it is alleged, at the University of Chicago and the University of Virginia, ${ }^{123}$ and others that are liberal and that only the conservative law school faculties have adopted law and economics. But that is simply not true. The characterization of the University of Chicago Law School faculty as particularly conservative is far out of date, if it was ever true. Moreover, there are law faculties that are well known for being leftist, such as that of the Yale Law School, ${ }^{124}$ that we believe have magnificent strengths in law and economics. The receptivity of law and economics in the United States is far too widespread to be explained by looking at the center of political gravity on particular faculties.

Second, we suspect that the political leanings of law school faculties in the United States and in Europe are reasonably close-namely, that they are generally left-of-center. Given the differences in the receptivity to law and economics but the similarities in terms of prevailing political ideologies of the faculties, there must be some other reason that explains the differences.

Third, if innovations in legal scholarship were to be explained by the prevailing political ideologies of law school faculties (in the sense that leftist faculties adopt leftist innovations and rightist faculties, rightist innovations-a view of which we are deeply skeptical), then one would expect the innovations to be skewed toward the left-of-center innovations and that those innovations would be the same, regardless of country, if the prevailing political ideologies were the same.

But the rate of adoption of innovations is very different. Left-of-center innovations, such as critical legal studies, have not caught on in either the United States or Europe. ${ }^{125}$ All sorts of innovations have had a fling in the United States-law and literature, law and society-but very few innovations have appealed to the relatively similar, in terms of political ideology, European law schools. ${ }^{126}$

\footnotetext{
TIMEs, Nov. 18, 2004, at available at http://www.nytimes.com/2004/11/18/education/18faculty.html. We have no reason for believing that the ratio between Democrats and Republicans on law school faculties is any different from that reported in the survey.

More generally, see John F. Zipp \& Rudy Fenwick, Is the Academy a Liberal Hegemony?: The Political Orientations and Educational Values of Professors, 70 PUB. OPINION Q. 304 (2006).

123. See, e.g., Graeme Browning, Reagan Molds the Federal Court in His Own Image, 71 A.B.A. J., Aug. 1985, at 60, 61 .

124. See, e.g., George W. Hicks, Jr., The Conservative Influence of the Federalist Society on the Harvard Law School Student Body, 29 HARV. J.L. \& PUB. POL'Y 623, 649 (2006) (discussing the liberal nature of the law faculty at Yale).

125. See generally Cass R. Sunstein, Foreword: On Academic Fads and Fashions, 99 MICH. L. REV. 1251 (2001).

126. See generally García-Villegas, supra note 104; Willem J. Witteveen, Law and Literature: Expanding, Contracting, Emerging, 10 CARDozo STUD. L. \& LITERATURE 155 (1998).
} 
There is another aspect of this phenomenon that is worth remarkingits potential path dependence. ${ }^{127}$ If right-leaning faculties tend to adopt rightist innovations and left-leaning faculties tend to adopt leftist innovations, then once a faculty tips one way or the other, that might set in motion a process that continually reinforces the starting political ideology of the faculty. If we add to this process a very plausible corollary that rightist faculties tend to hire other rightists and leftist faculties tend to hire other leftists, then there would seem to be an almost inevitable drift of faculties toward one extreme or the other.

Our impression is that this very rarely happens. We do not assert that there is necessarily a regression toward the mean such that faculties identify when they are straying too far in one ideological direction in their course adoptions, hiring practices, and other collective decisions. Or that university administrations correct perceptible ideological drifts in the constituent units of their universities. Or that external shocks, such as a change in the prevailing social climate, cause corrections. We have no idea which of these or similar forces are at work to prevent extreme ideologies from dominating scholarly disciplines. But subject to the observations made previously about the general left-of-center equilibrium in most college and university faculties, we strongly suspect that there are forces that prevent both ideological drift to extremes and the single-minded adoption of innovations according only to their political ideological content.

We conclude that both the characterization of law and economics as a rightist (or classically liberal) innovation is incorrect and that the prevailing political ideology of law school faculties does not provide much explanatory power in accounting for the rate of adoption of legal innovations.

\section{B. Money and the Success of Law-and-Economics}

A variation on the argument that finds political ideology to be a significant factor in explaining legal innovations generally, and the success of law and economics specifically, is that money plays an important role in the production and adoption of legal innovations. Could it be, for example, that the willingness of parties external to the academy to subsidize scholarly and other work in a particular innovation is a significant factor in explaining the academic success of that innovation? ${ }^{128}$

127. For more on this theory, see the discussion on "Informational and Reputational Cascades," infra at Subpart IV.J and text accompanying note 268.

128. We are speaking particularly of private external support for legal innovations. Research and other support provided by the government-through, say, the National Science Foundation in the United States-might have a notable effect on the adoption or furtherance of innovative scholarship, but we do not focus on that possibility here. We recognize that this may be a mistake because public support may be (and in theory is) a very important factor in explaining academic innovation, particu- 
That is an argument that we have frequently heard in explaining the spread of law and economics in North America ${ }^{129}$ By implication the argument, as we interpret it, makes two important and broad claims:

(1) that a significant factor in explaining the acceptability of any legal innovation is the availability of external (to the academy) resources available to proponents of the innovation; and

(2) that innovations that lack that external help will have a more difficult time succeeding than the merits of the innovation would otherwise dictate.

In this part we shall first sketch the mechanisms that this contention postulates and then evaluate whether this contention helps to explain recent patterns of legal innovations. ${ }^{130}$

For our purposes here, and to illustrate how this mechanism might be said to work, let us assume that at any given time there are a host of innovations assailing the legal academy. One might think, for concreteness, that large numbers of younger scholars are seeking to make their way in the discipline by undertaking original work that adopts some innovative method of examining a legal topic. Some of these innovations are more plausible than others, but we could even assume that they are uniformly distributed across some plausibility spectrum.

Now suppose that after an innovation has appeared in the work of one or a few legal scholars, an external group identifies that legal innovation as very congenial to its goals or view of the world. And if that group has

larly in the basic and natural sciences. We focus on the role of private sources of support because those sources have been frequently referred to as critical to the academic success of law and economics. See infra note 129. There is, however, a very important difference between the United States and Europe with respect to accessibility to private and public funds for research. We shall comment on the effect of those differences below. See infra notes 129-142.

129. See, e.g., Jon Hanson \& David Yosifon, The Situation: An Introduction to the Situational Character, Critical Realism, Power Economics, and Deep Capture, 152 U. PA. L. ReV. 129, 272-78 (2003). Therefore, the argument is usually not so much about the different reaction to law and economics in the United States and Europe, but rather to explain the expansion of law and economics within U.S. legal academia. See, e.g., id. Although we do believe that having the Olin Foundation putting $\$ 50$ million into European legal academia to do law and economics would have made no big difference for the reasons we advance in our explanation about the organization of legal academia in Europe, see infra Subpart IV.D, we think this is a quite important argument that deserves being addressed in the paper. Indeed, we noted above that the designation of the European Program in Law and Economics as an Erasmus Mundus program and the significant sum of money that that designation had brought to the lead schools--Rotterdam and Hamburg-in the Program has caused the faculties of law at both schools to pay far greater attention to law and economics than they did before the influx of money. See supra note 50.

130. We shall argue in our model of legal innovation in Part $V$ that the costs of adopting an innovation are an important determinant of the success of a new scholarly method of looking at the law. So, to the extent that some external factor lowers the cost of adoption, we would confidently expect the innovation so subsidized to be more likely to be adopted than it would be if it were not subsidized. 
the resources, it will seek to further that innovation by making funding available to those schools and those scholars who are likely to continue work in that area. It is even possible that some scholars who otherwise would not have found that innovation a plausible or attractive method of conducting their research projects might find the funding possibilities so alluring that they switch to the innovative method of scholarship in an effort to win a share of the external funding.

The question that now arises is whether this sketch is a helpful guide to the pattern of recent innovations in the legal academy. For instance, could one plausibly explain the demise of critical legal studies by the fact that it had no external resources to subsidize its adoption? Similarly, could the presence of substantial external support for law and economics be a significant factor in explaining both the North American success of that innovation and the lack of its success in other parts of the world? From a social viewpoint, what would be particularly disquieting would be the situation in which a non-meritorious innovation gets a boost from external sources and then entrenches itself in the academy through, for example, some variant of the path-dependent hiring practices mentioned in the previous part. If there was reason to believe that there are some innovations that ought not to have been adopted (because, for example, they bias research agendas or distort the search for scholarly truth) but that have been adopted and become influential in the academy, then one would have cause to be deeply concerned.

We cannot think, in the history of the last several hundred years, of a scholarly innovation in any field that was adopted and held sway over an academic discipline because of money made available by external sources and was then later shown to have been wrong at the time that it was adopted. That is, money has never, to our certain knowledge, managed to purchase an entire discipline's point of view that would have been correctly rejected but for the support of external money.

That is not to deny that money can assist an innovation to get a hearing. There are, after all, many potential innovations (at least in the United States) competing for the time and attention of legal scholars. An innovation that can spread itself through such devices as eye-catching publications, conferences in attractive locales, subsidized publication by prominent journals or university presses, and grants for writing time released from teaching obligations is an innovation that might attract interest. ${ }^{131}$

Our point, however, is that in the long run the true test of any legal scholarly innovation is its ability to become accepted for its scholarly worth. This is, we believe, a general characteristic of all disciplines within

131. See e.g., Gazal-Ayal, supra note 52, at 789 n.6 (reporting that the Olin Foundation has donated over $\$ 300$ million in support of law and economics projects and scholars). 
the modern research university - the ability to filter helpful scholarly innovations from those that are inaccurate or unhelpful. The processes of publication, promotion, evaluation, and consideration for positions at other universities and in private employment all serve to weed out "good" from "bad" scholarly innovations. We shall elaborate on these processes later in this part.

There are other good reasons for not believing too fervently in this "scholarship follows the money" theory of legal innovation. First, most scholars are fiercely independent, as anyone who has attempted to bend a faculty to his or her view of things can testify. ${ }^{132}$

Second, universities seem particularly sensitive to charges that their neutrality has been compromised by external funding and have put in place fairly stringent and effective mechanisms for guarding against suspicions that their research results were "purchased" in exchange for external funding. As an example, one might think of an agricultural pesticide company's willingness to fund research that leads to findings that pesticides have no environmental harm, tobacco companies' seeking to fund research that downplays the health risks of tobacco consumption, and a wealthy individual's offering to donate a large sum of money in exchange for a department's commitment to hire a faculty member of a particular political persuasion. Our strong belief is that every reputable university anywhere (not just in North America), no matter how hard-pressed for more funds, would strongly resist becoming involved in any of these escapades. It simply is not worth it to compromise one's scholarly reputation by taking funding in exchange for particular scholarly results.

Third, for money to be able to induce the general acceptance of a legal innovation, we need to supplement the money hypothesis with either a conspiracy theory or a manipulation theory. For instance, there must be some fraction of those who adopt the innovation who are knowingly intellectually dishonest. That is, they know or strongly suspect that the innovation is wrong, but they follow it in pursuit of the money. In addition, those who were previously critical of the innovation must be purchased to stop their criticism. And new conspirators must continually be brought into the conspiracy-strategic defectors who seek to get a better deal by threatening to expose the conspiracy; new young faculty who must be initiated into the conspiracy; and university administrators, who must be constantly reassured that this is a genuine scholarly innovation and not simply an outside group unduly influencing an academic unit.

132. Robert Maynard Hutchins, a lawyer and former president of the University of Chicago, once said, "A university is an aggregation of separate sovereignties 'connected . . . by a common heating plant." See Milton MAYER, Robert Maynard Hutchins: A MEMOIR 97-98 (John H. Hicks ed., 1993), available at http://ark.cdlib.org/ark:/13030/ft4w10061d/. 
As everyone knows, conspiracies that involve more than one person are fragile. And a conspiracy among a large number of academics in different universities seems to us to be a ludicrous idea. Alternatively, scholars could be manipulated into accepting the innovation through a widespread delusion or hysteria. That is, they must be persuaded that the emperor's new clothes are, all appearances to the contrary notwithstanding, gorgeous. ${ }^{133}$

Fourth, if either the conspiracy or manipulation hypothesis is correct and law-and-economics proponents are members of a conspiracy or suffer from a mass delusion, there should be a separating equilibrium, ${ }^{134}$ with some schools specializing in law and economics and some not. But actually what one has is a mixed or pooling equilibrium in which each faculty has some people from law-and-economics and some people from other disciplines. Harvard has Duncan Kennedy and Steve Shavell. ${ }^{135}$ Yale has Jack Balkin and multiple law and economics scholars. ${ }^{136}$ Stanford has Mark Kelman and Mitch Polinsky. ${ }^{137}$ It seems that the vast majority of law schools do not specialize in one or another of the various legal innovations that have appeared in the last several decades. They all seem to recognize that they are far stronger if they have mixed faculties of competing and different views. Thus, old-fashioned though it may sound, the academy is one of the few places in our society where people with contending views

133. We cannot imagine psychological heuristics and biases that might explain the persistence of the conspiracy or the widespread delusion. Such well-known phenomena as excessive optimism about one's abilities and the status quo bias (which makes human beings more content with the way things are and more reluctant to change to alternative states than the relative merits of the status quo and the alternatives warrant) would seem to argue for a reluctance to innovate more than a desire to innovate simply for the sake of innovation-thereby making it more likely that "bad" innovations will succeed. See generally Russell B. Korobkin \& Thomas S. Ulen, Law and Behavioral Science: Removing the Rationality Assumption from Law and Economics, 88 CAL. L. REV. 1051, 1091-95, 1107-13 (2000). True, academics are like everyone else in being subject to biases and heuristics, but they are also more inquisitive and rebellious than most people, characteristics that make them particularly unfertile ground into which to plant the seeds of conspiracy or hysteria.

134. The notions of " separating" and "pooling" equilibria come from screening and signaling games. See Avinash Dixit \& SuSAN SKEATH, Games OF STRategy 412-26 (1999). To understand these equilibria, imagine a situation in which employers and potential employees are trying to sort themselves out. Suppose that there are two types of potential employees-hardworking and indolent. The prospective employees know which type they are, but it is difficult for employers to distinguish between the types prior to their work experience with the firm. (This is a situation of "information asymmetry.") See id. at 414 . The hardworking potential employees would like to find a signal that they can send that clearly distinguishes them from the indolent potential employees. The indolent potential employees would like all signals about one's type to be muddy and inconclusive so that they have at least as high a probability of being hired as do the hardworking employees. The employers would like to be able to screen the potential employees into their appropriate type. If there are perfect screening and signaling devices, then there can be a "separating equilibrium"; if not, then there is a "pooling equilibrium" in which some indolent workers are mistakenly hired and some hardworking workers are mistakenly not hired. See id. at 416-24.

135. See ASs'N OF Am. LAW SChOOLS, The AALS DiRECTORY OF LAW TEACHERS: 2005-2006, at $650,1306$.

136. See id. at $252,1305-06$.

137. See id. at 649,870 . 
willingly and nonviolently clash and discuss differences with a shared view of advancing collective understanding through passionate, reasoned argumentation.

In the long run and sooner or later, innovations must prove their worth to the scholars learned in the discipline. As a result, those innovations that we now know are wrong-alchemy, the notion of an ether, theological justifications for governance structures (all examples of views for which people were castigated for contesting these ideas)-simply do not survive in a vibrant, competitive academy.

Ultimately our sense is that the academy is almost always skeptical of innovation, that there is what Thomas Kuhn called a "paradigm" that has a powerful grip on any entrenched discipline within the academy. ${ }^{138}$ What Kuhn called a "paradigm shift" away from that conventional paradigm occurs only when a compelling alternative presents itself. ${ }^{139}$ That is, every discipline is conservative with respect to change: those learned in the discipline have made a significant investment in the prevailing paradigm and must incur significant costs in investing in a new paradigm. Presumably they will incur those costs only when there is a high return to doing so. Remember that the scientific revolution itself was an innovation that took a long time to become accepted. ${ }^{140}$ And think how difficult it was for geology to accept the plate tectonic theory. ${ }^{141}$ If this is, as we believe it to be, a fair characterization of most academic disciplines, the burden on legal innovations to prove their worth is very high. And money is not one of the criteria that figures most prominently in the acceptance of any scholarly innovation at large. ${ }^{142}$

\section{Common Law versus Civil Law}

Another frequent assertion is that the receptiveness to legal innovation has to do with the characteristics of the different underlying legal systems with the common law systems being amenable to (if not demanding of)

138. See KUHN, The STRUCTURE OF SCIENTIFIC REvolutions, supra note 34, at 10-13.

139. See id. at 23-34.

140. See generally ALFRED W. CROSBY, THE MEASURE OF REALITY: QUANTIFICATION AND WESTERN SOCIETY, 1250-1600 (1997); LISA JARDINE, INGENIOUS PURSUITS: BUILDING THE SCIENTIFIC REVOLUTION (1999). See also the fictionalization of the remarkable story of the empirical revolution in Europe in NEAL STEPHENSON, QUICKSILVER (2003), THE CONFUSION (2004), and THE SYSTEM OF THE WORLD (2004).

141. See, for many examples, not just that of plate tectonics, BILL BRYSON, A SHORT HISTORY OF NEARLY EVERYTHING (2003).

142. For a discussion of these processes in modern economics, see Roger E. Backhouse, The Rise of Free Market Economics: Economists and the Role of the State Since 1970, in Symposium, The Role of Government in the History of Economic Thought, 37 HIST. POL. ECON. 355 (Steven G. Medema \& Peter Boettke eds., Supp. 2005), available at http://hope.dukejournals.org/cgi/reprint/37/Suppl_1/355. 
law and economics (or similar innovations) and, by implication, the civil law systems not needing innovations. ${ }^{143}$

Why would the common law systems demand legal innovations, particularly law and economics? The common law, it is sometimes argued, ${ }^{144}$ is much more receptive to law and economics than is the civil law system. One hallmark of the common law is that it is necessarily "undertheorized"145 in the sense that a common law judge's decision of a dispute is not an instantiation of an explicit theory for resolving disputes of the type before him or her. Rather, common law judges work incrementally, fitting seemingly new fact patterns into existing precedent without overly scrupling to articulate the theory of the area of the law that the dispute represents. ${ }^{146}$

This undertheorization of the common law process might create a significant demand for unifying theory. First, because it does not strive to be comprehensive, the common law necessarily has gaps in its coverage. Judges cannot fill those gaps until presented with fact patterns that demand gap-filling decisions. Commentators-for example, law professors and such groups as the American Law Institute through its Restatements-can fill the gaps by suggesting an overarching theory or systematization (with comments and illustrations) that comprehends both the decided cases and those that might be presented in the interstices of those cases.

By contrast, the civilian legal systems provide a theory of areas of the law in the form of the enabling codes that judges then apply to individual cases. Commentators-such as law professors-do not need to supply the theories; rather, their principal task is to explicate the theory embodied in the code or to show how the theory needs refining. Almost never do they need to re-characterize the theory-it is already provided to them.

143. See, e.g., Grant M. Hayden \& Stephen E. Ellis, Law and Economics After Behavioral Economics, 55 U. KAN. L. REV. 629, 634-36 (2007).

144. See, e.g., Richard A. PosNer, LAw AND Legal THeory In ENGLAND AND AmeriCa (1996) [hereinafter POSNER, LAW AND LEGal THEORY]; RICHARD A. POSNER, OVERCOMING LAW (1995) [hereinafter POSNER, OVERCOMING LAW] (especially Chapter 1, "The Material Basis of Jurisprudence"); Richard A. Posner, The Future of the Law and Economics Movement in Europe, 17 INT'L REV. L. \& ECON. 3 (1997) [hereinafter Posner, The Future of the Law and Economics Movement in Europe]; Richard A. Posner, Law and Economics in Common-Law, Civil-Law, and Developing Nations, 17 RATIO JURIS 66 (2004). For the perspective of a distinguished British scholar of corporate law, see Brian R. Cheffins, The Trajectory of (Corporate Law) Scholarship, 63 CAMBRIDGE L.J. 456, 457 (2004), who identifies five potential developmental paths for legal scholarship. For a particular argument about contract law and the civil law system's reluctance to adopt any theory, see Aristides N. Hatzis, The Anti-Theoretical Nature of Civil Law Contract Scholarship and the Need for an Economic Theory, in 2 COMMENTARIES ON LAW \& ECONOMICS 1 (2002).

145. See generally Cass R. Sunstein, Incompletely Theorized Agreements, 108 HARV. L. REV. 1733 (1995).

146. See id. at 1749 (" $[\mathrm{P}]$ recedents can lower the level of theorization by making more foundational views irrelevant or even inappropriate and by binding judges to outcomes that they would like to reject."). 
Second, a frequent claim about the common law is that, in the words of Lord Mansfield, it tends to "work[ itself pure" ${ }^{\text {"147 }}$-that is, to get things right eventually. Or, to put the claim in its modern form, the common law tends towards efficiency. The gist of that contention is that in a common law system there are incentives for repeat players to litigate inefficient rules but not to litigate efficient rules; whether judges decide cases by a flip of a coin, by the satisfactoriness of their breakfast, by consulting an ideological template, or by close analogical reasoning to precedent, this mechanism will inevitably lead to an increase in the stock of efficient legal rules. ${ }^{148}$ This increase, one might then suggest, would lead to some scholars' trying to work out why the laws were developing in a particular direction, and this inquiry might then lead to law and economics.

Third, one might read this argument to make a negative contention that systems that rely upon legislatures to make the bulk of their law are inevitably going to have less efficient laws because legislatures pay more attention to distributive matters than to efficiency. ${ }^{149}$ So if the bulk of law in the common law systems is judge-made and is tending toward efficiency, and the bulk of law in the civil law system is legislative and is not moving noticeably toward efficiency, then there is likely to be a much greater interest in efficiency in the common law than in the civil law systems. ${ }^{150}$

There are two problems with these last two explanations for why law and economics is more suitable for common than for civil law. First, the selective litigation hypothesis (which holds, among other things, that there is an incentive to litigate inefficient but not efficient rules) should be true in any legal system or, possibly, is only slightly stronger in the common than in the civil law. The key difference between the systems in this regard is that judges can clearly make law in the common law system while judges are more constrained in making law in the civil law system. As a result, the incentive to litigate an inefficient rule might be less strong in a system that did not allow judges to alter the inefficient rule. But most comparatists downplay this distinction between the systems, finding almost the same flexibility to alter law in both systems. ${ }^{151}$ It could be, moreover,

147. Omychund v. Barker, (1744) 26 Eng. Rep. 15, 23 (Chan.).

148. See generally COOTER \& ULEN, supra note 46; Nicola Gennaioli \& Andrei Shleifer, The Evolution of the Common Law, 115 J. POL. ECON. 43 (2007); Gillian K. Hadfield, Bias in the Evolution of Legal Rules, 80 GEO. L.J. 583 (1992); George L. Priest \& Benjamin Klein, The Selection of Disputes for Litigation, 13 J. LEGAL STUD. 1 (1984); Paul H. Rubin, Why Is the Common Law Efficient?, 6 J. LEGAL STUD. 51 (1977).

149. This is a common contention in the public choice literature on legislatures. See generally FARBER \& FRICKEY, supra note 29.

150. See, e.g., Dau-Schmidt \& Brun, supra note 113, at 616-19.

151. For a view that common law systems may be more inclined to be efficient than are civil law systems, see generally Paul G. Mahoney, The Common Law and Economic Growth: Hayek Might Be Right, 30 J. LEGAL STUD. 503 (2001). For a demonstration that differences between common law and 
that even if this difference is true, repeat players in the civil law system may have a strong incentive to make repeated appeals to the legislature for relief.

Second, there is no particular reason why legislatures are not just as interested in the economic analysis of law as are common law judges. Indeed, we can think of reasons why legislatures, to the extent that they are always balancing costs and benefits at numerous margins, should be even more interested in economics than are judges. ${ }^{152}$

These characterizations may be correct, but they are not, we believe, helpful in explaining the difference between Europe and the United States in their receptivity to law and economics. Consider, first and foremost, the curious instance of England and Wales. Although England is the home of the common law system, England and Wales have been, like continental Europe, conspicuously uninterested in law and economics. ${ }^{153}$ If the connection between common law and law and economics was strong, then England ought to have a vigorous interest in law and economics. But clearly it does not. ${ }^{154}$

civil law participants with respect to litigation are smaller than expected, see generally Tom Ginsburg \& Glenn Hoetker, The Unreluctant Litigant?: An Empirical Analysis of Japan's Tum to Litigation, 35 J. LEGAL STUD. 31 (2006).

152. This observation has some further implications. First, as we shall argue below, the European Union is finding law and economics to be of particular interest in its implementation of directives, an essentially legislative act. See infra text accompanying notes 313-315. Second, some, such as Posner, have argued that England is more like the continent than the United States in that it has a parliamentary system and that parliamentary systems are not particularly disposed to find law and economics useful. See LAW AND LEGAL THEORY, supra note 144, at 1-112; Dau-Schmidt \& Brun, supra note 113, at 616-19. This point might be used to show why the United Kingdom, even though a common law country, is more like the continental systems in relying relatively more on legislative than on judicial governance.

153. One might even argue that if the connection between the common law and the attractions of law and economics was so strong, then England should have been the originator of law and economics. Of course, in a sense it was, in that Ronald Coase is English. See Richard A. Posner, The Future of the Law and Economics Movement in Europe, supra note 144, at 4. And more broadly modern economics originated and was nurtured in Scotland and England, and those countries' current economics profession is one of the most distinguished in the world. See generally Ejan Mackaay, History of Law and Economics, in 1 ENCYCLOPEDIA OF LAW AND ECONOMICS 65 (Boudewijn Bouckaert \& Gerrit De Geest eds., 2000), available at https://papyrus.bib.umontreal.ca/dspace/bitstream/1866/86/1/0029.pdf.

154. The best collections of legal scholars in the United Kingdom-including the Universities of Durham, Keele, Southampton, King's College, the London School of Economics, and Queen Mary College of the University of London-to our knowledge do not have a single scholar active in law and economics, and only Cambridge University (Brian Cheffins), Oxford University (John Armour), the University College of London (Timothy Swanson), the University of Manchester (Anthony Ogus, Frank Stephen, Andrew Griffith, Dennis Khong and Nuno Garoupa with a twenty percent appointment), and the University of East Anglia (Morten Hviid) law schools have active law and economics senior scholars that we know of. To our knowledge, most of the (relatively few) active law and economics scholars in the United Kingdom are in departments of economics in provincial universities such as Nottingham, Royal Holloway, Surrey, York, Hull, St. Andrews, Leicester or Edinburgh. There are no law professors active in law and economics in Ireland and virtually none in Scotland and Wales that we know of. See also discussion supra note 79. See generally Christopher McCrudden, Legal Research and the Social Sciences, 122 LAW Q. REv. 632, 639-40 (2006) (discussing why counter- 
Incidentally, the example of England disproves another possible hypothesis that originates in the work of Posner. That hypothesis is the contention that law and economics stems from original work in a vibrant economics profession. ${ }^{155}$ The suggestion seems to be that a necessary and perhaps sufficient condition for the development of interest in law and economics is that there are fascinating things going on in disciplines contiguous to the law. For instance, one might argue that there has to be interest generally in nonmarket economics, such as the economics of the family and of discrimination, in order for interest to develop in law and economics. Only through that mechanism can outsiders to economics see the applicability of the technical work of economists to their own discipline.

There are other puzzles about the contention that law and economics is appealing only to common law countries. India, the largest common law country, has virtually no interest in law and economics. ${ }^{156}$ Australia and New Zealand have a very small (but highly productive) number of law professors engaged in law and economics, although there is an AUSLEA (Australian Law and Economics Association). ${ }^{157}$

On the other side of the ledger, Israel, a civil law country, has a large number of law-and-economics scholars working at home and in the United States. ${ }^{158}$ Their young scholars routinely come to the United States to get advanced degrees, and frequently those degrees concentrate on law and economics. ${ }^{159}$ Their young professors are encouraged to publish in U.S. law reviews and told that establishing a reputation in the North American legal academy is extremely important for their professional success. ${ }^{160}$ The Netherlands, another civil law country, has broadly engaged law and economics. ${ }^{161}$

intuitive results produced by law and economics scholarship makes it less appealing to legal scholars in the United Kingdom).

155. See POSNER, OVERCOMING LAW, supra note 93, at 3.

156. There are extremely distinguished law and economics scholars who are South Asian (among them Akhil Amar, Vik Amar, Jagdish Bhagwati, Dhammika Dharmapala, Avinash Dixit, and Mitu Gulati), but all of them are expatriates working in U.S. law schools or departments of economics. There has been, since mid-2005, some stirring of interest in law and economics in Indian Departments of Economics and in Indian Faculties of Law, and the National Law School of India University, Bangalore, India hosted the Asian Law and Economics Association Annual Meeting in December, 2006. See Asian Law \& Econ. Ass'n, Second Annual Conference, Law and Governance: Institutions for the Asia-Pacific Century, Call for Papers, http://aslea.org/paper/call.pdf.

157. See Australian Law and Economics Association Homepage, http://law.anu.edu.au/cle/austlea/ (last visited Oct. 22, 2007)

158. See Gazal-Ayal, supra note 52, at 794-97.

159. See id. at 798.

160. Id.

161. See supra note 109 and accompanying text. Notice, for example, that the predictions concerning expansion of law and economics made by Robert D. Cooter \& James Gordley in Economic Analysis in Civil Law Countries: Past, Present, and Future, 11 INT'L REV. L. \& ECON. 261, 261-63 (1991), have largely not come to pass. 
Canada presents a particular puzzle. That country takes much of its lead in legal matters from England, and yet with respect to law and economics, it takes its lead from the United States, being almost as receptive to law and economics as has been the United States. ${ }^{162}$ The leading Canadian law school, the University of Toronto, has been a world leader in the development of law and economics as a scholarly enterprise. ${ }^{163}$ It has hosted a vital and vibrant annual conference for the Canadian Law and Economics Association; ${ }^{164}$ Professor Michael Trebilcock was one of the founders of the American Law and Economics Association and has been that organization's president, ${ }^{165}$ and its former dean, Ron Daniels, was a finalist to be the Dean of Columbia Law School. ${ }^{166}$

So, somewhat surprisingly, we do not see any reason inherent to the common law or civil law systems that makes one or the other more congenial either to legal innovations generally or to law and economics particularly. Nor does the actual interest in law and economics line up clearly along a common law-civil law divide.

\section{The Structure of Legal Education}

Those seeking to explain the difference between the United States and Europe with respect to the receptivity to law and economics frequently point to two very different aspects of legal education as being important. First, they note that in the United States, almost uniquely in the world, legal education is post-graduate education. ${ }^{167}$ Except for a few countries (Japan and the Republic of Korea) that are currently revising their legal education systems to look more like that in the United States, most lawyers in the world receive their legal education by taking law as their undergraduate major. ${ }^{168}$ That is simply impossible in the United States. We shall elaborate below, ${ }^{169}$ but the gist of this contention is that every U.S. law student comes to the study of law having already studied some other subject intensely. So, the argument goes, U.S. law students, being both

162. See Gazal-Ayal, supra note 52, at 788, 795 .

163. See generally University of Toronto, Law and Economics Programme Homepage, http://www.chass. utoronto.ca/economics/lawec.html (last visited Oct. 22, 2007).

164. See Canadian Law and Economics Association Homepage, http://www.canlecon.org/ (last visited Oct. 22, 2007).

165. University of Toronto, Professor Michael J. Trebilcock, http://www.provost.utoronto.ca/Awards/uprofessors/current/Professor_Michael_J_Trebilcock.htm (last visited Oct. 22, 2007).

166. See generally Penn Law Faculty: Ron Daniels, http://www.law.upenn.edu/cf/faculty/rdaniels/ (last visited Apr. 4, 2008)

167. See POSNER, LAW AND LEGAL THEORY, supra note 144 , at 70.

168. Cheng Han Tan, Gary Bell, Xuan Hop Dang, Joongi Kim, Keang Sood Teo, Arun Thiruvengadam, V. Vijayakumar \& Jiangyu Wang, Legal Education in Asia, 1 ASIAN J. COMP. L. art. 9, at 78 (2006), http://www.bepress.com/asjcl/voll/iss1/art9/.

169. See infra Subpart IV.D.1. 
more mature and already educated in some other field, are more inclined than are those who are either younger or learned in nothing else (or both) to see the law through the lens of some other field.

Second, higher education, including legal education, in the United States is a highly competitive industry, while higher education in other countries is not nearly as competitive. ${ }^{170}$ As a result, in the United States there is a strong incentive for each law school to adopt policies that will make that school better so as to attract more and better students, better faculty, and more resources. This incentive is pervasive in American higher education, not just in law schools. ${ }^{171}$ Although there are many firstrate institutions of higher learning outside North America, they do not yet have the same incentive to compete as vigorously as do the U.S. colleges and universities. ${ }^{172}$ To the extent that competition includes, as it does, an incentive to adopt innovate scholarly methods, then this competitive spur to innovate may explain why U.S. law schools have adopted law and economics (and other innovative methods of examining law) and European schools have not.

In this part we shall lay out and then evaluate these two arguments.

\section{Law as a Graduate or Undergraduate Education}

Legal education in the United States is almost unique in the world in the sense that it is exclusively a postgraduate education, consisting of three years of education after the student has already completed a baccalaureate degree in some other, non-legal field. ${ }^{173}$ It is impossible to study law for the baccalaureate degree in the United States, although one can take cognate majors in forensic studies or criminal justice studies, majors that typically lead not to careers as lawyers but in the criminal justice system. ${ }^{174}$ In

170. See Secrets of Success, ECONOMIST, Sept. 10, 2005, Supp. at 6, 6; see also infra note 190 .

171. See Secrets of Success, supra note 170, at 6

172. In 2005, the Shanghai Jao Tong University published its survey of world universities. Shanghai Jao Tong University International Ranking, http://www.universitymetrics.com/tiki-index.php (last visited Oct. 2, 2007). Of the top twenty world universities, seventeen are in the United States. The Brains Business, ECONOMIST, Sept. 10, 2005, Supp. at 3, 3, 4, available at http://www.economist.com/displaystory.cfm?story_id=4339960. Eight of the top ten are in the United States (the Universities of Cambridge and Oxford are ranked \#3 and \#8), and the University of Tokyo (at \#14) is the only non-U.S. university in the second ten. Id. at 4 tbl.1. The London Times Higher Education Supplement has recently published its own 2005 survey of world universities. See International Comparisons, The World's Top 200 Universities, http://jahanzeb.com/download/World_Top_200_Universities.pdf (last visited Oct. 2, 2007). Of the top twenty world universities in the Times survey, twelve are in the United States. Id. Seven of the top ten are U.S. universities, and five of the second ten are U.S. universities. Id. The non-U.S. universities in the Times survey, in rank order, are Cambridge (\#3), Oxford (\#4), Ecole Polytechnique (\#10), the London School of Economics (tied for \#11), Imperial College London (\#13), Beijing University (\#15), Tokyo University (\#16), and Melbourne University (\#19). Id. Of the top 200 universities, 54 are U.S. universities. Id.

173. See POSNER, LAW AND LEGAL THEORY, supra note 144 , at 70 .

174. See, e.g., University of Cincinnati, Division of Criminal Justice, 
the rest of the world ${ }^{175}$ the study of law is a baccalaureate or undergraduate course of study. ${ }^{176}$

Some argue that there is a strong connection between the fact that students in the United States have already completed studies in a nonlaw major and the welcoming reception to law and economics in the United States ${ }^{177}$ The chain of causation is somewhat obscure but might run as follows. Because U.S. law students have already achieved some depth of knowledge in other disciplines, they come to the study of the law through a variety of different disciplinary lenses. Those who were undergraduate engineering majors see the law through a technical or engineering lens. Those who were English literature majors see it as an interpretive exercise like the textual exegeses that formed the core of their undergraduate studies. Those who were political science majors see the law as a meeting ground of political interests. Those who were anthropology or sociology majors see the law through the lens of social group formation and interaction or through the push and pull of impersonal social forces. Those with a historical background are struck by the historical, path-dependent aspects of law. And those who were undergraduate economics majors may be struck by the efficiency aspects of legal rules. ${ }^{178}$

This stew of different disciplinary backgrounds, the argument suggests, makes U.S. law students far more open to multiple ways of looking at the law. Because nearly all U.S. law professors were once students of something else, they, too, find this cross-disciplinary method of approaching law to be congenial. So, they as well as their students are receptive to innovations that come to the law from other disciplines.

As with all the other explanations that we have canvassed for the differences between the United States and Europe with respect to the receptivity to law and economics and other legal innovations, there are problems with this one, too. At the most general level, this explanation does not seem to distinguish law adequately from other disciplines in the acad-

http://www.uc.edu/criminaljustice/ (last visited Oct. 22, 2007).

175. Japan and South Korea have recently (Spring, 2004) reformed their legal education systems to include postgraduate education in law on the U.S. model. Tan et al., supra note 168, at 7. The reasons for these reforms are complex. In Japan, the central reason given is to increase the number of attorneys in Japan from the very low per capita figure today to a figure approximating that in France, which has the lowest percentage of lawyers per capita of any developed country. See Recommendations of the Justice System Reform Council, www.kantei.go.jp/foreign/judiciary/2001/0612report.html (last visited Oct. 3, 2007); see also Tan et al., supra note 168, at 7.

176. See generally Dau-Schmidt \& Brun, supra note 113.

177. See POSNER, LAW AND LEGAL THEORY, supra note 144 , at 70.

178. The lack of mathematical training of law students outside of the United States is usually presented as a major reason for the rejection of law and economics. If valid, such argument only applies to law and economics, not to other legal innovations. Furthermore, most of the law and economics literature published in law reviews does not require an extremely advanced training in mathematical modeling. Nevertheless, we should recognize that the opportunity cost of acquiring mathematical skills is not negligible, and therefore, we observe in Europe a certain tendency for softer socio-legal studies rather than a more technical economic approach. See also discussion supra note 104. 
emy. The hypothesis can be understood to be making one of two claims: either that no scholarly innovation will succeed where students' first and only brush with the topic is as undergraduates or that scholarly innovations will occur only when students' first brush with it occurs in a postbaccalaureate context. Either view seems implausible. And if either is a theory generalizable to other subjects within the university, we should be greatly surprised. At any rate, neither applies to the study of business, a field in which there has been significant scholarly innovation, regardless of whether the first and only education in that field is at the undergraduate or graduate level. ${ }^{179}$ Nor could the second prong of the hypothesis be seriously applied to the study of medicine anywhere in the world.

Another significant problem with the theory that there is a strong (casual) connection between postgraduate legal education and the production and adoption of law and economics (and other legal innovations) is that there are three examples of countries that have law as an undergraduate education-Canada, Israel, and the Netherlands-but that have adopted law and economics as an important part of their legal education and their approach to legal scholarship. ${ }^{180}$

Yet another problem is that in some continental European legal educations the course of study is five years and allows for significant other disciplines to figure in the education. ${ }^{181}$ In Italy, for instance, almost every law student is required to take courses in microeconomic theory and public finance. ${ }^{182}$ In Belgium, the typical law student must complete cognate courses in other subjects as part of the undergraduate legal degree. ${ }^{183}$ These systems seem to have significant similarities to the situation in the United States, so that if it were the familiarity with another discipline prior to the first exposure to law that were controlling in the adoption of legal innovations, then Italy and Belgium should be nearly as innovative as the United States legal academy. But they clearly are not.

In this discussion, we should also realize that legal education, although undergraduate across Europe, is quite different on the continent from what

179. See Harry DeAngelo, Linda DeAngelo \& Jerold L. Zimmerman, What's Really Wrong With U.S. Business Schools? 2-3 (July 2005) (unpublished working paper), available at http://papers.ssm.com/sol3/papers.cfm?abstract_id=766404 (identifying a history of development in business school faculty as progressing from practice- to scholarship-oriented that is much like that of modern U.S. law schools).

180. See supra notes $111-112$ \& 161-166.

181. See, e.g., EVA STEINER, FRENCH LEGAL METHOD 192-93 (2002).

182. See Italy Law Schools, http://www.hg.org/law-schools-italy.asp (last visited Apr. 4, 2008) (listing Italian Law schools and linking to curriculum web pages); see also Gazal-Ayal, supra note 52, at 806-08 tbls.1, 2 \& 3 (tabulating data that shows increased activity in the areas of economics and finance by Italian law professors).

183. See, e.g., Minors and Electives in Dutch Law Study Program, http://www.unimaas.nl/default.asp?template = werkveld.htm\&id =60AX1403G22B6PN1L504\&taal =e n\#SI671UCOCQD6E33N7WT6 (last visited Apr. 4, 2008) 
it is in England and Wales in terms of tradition ${ }^{184}$ and teaching methods. ${ }^{185}$ Whereas English legal education is vocational and policy discussions dominate over legal complexity (law reports are a primary source), French legal education emphasizes theoretical knowledge and logical and formal arguments rather than a pragmatic, discursive approach. ${ }^{186}$ It is not clear in which of these two models we should expect "law and economics" to be more influential. As fertile ground in which to plant any legal innovation, a theoretically oriented education would seem to be more congenial. But the concern for policy discussions would also make law and economics quite attractive. However, in both models, law and economics has failed to become important.

A third problem with the theory is that it does not satisfactorily explain what would appear to be a central tenet of any legal education system-to inculcate in students a discipline-specific methodology and set of precepts. Even in the United States, one of the central goals of the first year of legal education is said to be to get the new student "to think like a lawyer"-whatever that may mean. At first blush, there should seem to be just as much effort in the United States as elsewhere directed at getting the students to forget what they might have learned before and pay attention to what the learned professors are telling the students that they need to know. Our sense is that nothing much would change in U.S. legal education if the average age of law students fell by four years (the length of U.S. undergraduate education) or rose by ten years. Nor would we expect receptivity to legal innovation to change in either England or France if they adopted U.S. teaching methods or converted legal education to graduate study. Nor would we expect the U.S. attraction to innovation to fade if we were to adopt French or English methods of education.

A fourth problem with the hypothesis is the unlikelihood that the character or background of a discipline's students would have such a profound effect on the nature of the scholarship that the professors in that discipline practice. Rather, most professors, in whatever discipline, would seem to take pride in dictating the nature and content of their disciplinary education with no regard whatsoever for the sensibilities of their students. Students had better accommodate themselves to what the professors expect or

184. The continental tradition follows Roman law while England follows the common law. STEINER, supra note 181, at 197-201. Some scholars, such as POSNER, LAW AND LEGAL THEORY, supra note 144, at 20-21, and Dau-Schmidt \& Brun, supra note 113, at 611-12, believe that this distinction is more fictitious than real.

185. French teaching methods rely on large groups of studems, a wide-ranging liberal education not dedicated to a single subject or profession, and an emphasis on abstract concepts and methodology; English teaching emphasizes specific needs and habits of a dominant profession with particular concern for practice or vocational studies. STEINER, supra note 181, at 191-92. Many of these attributes result from a general consideration between a narrow specialized model of higher education in Europe and a generalist model of higher education in the United States. See id. at 195-97.

186. Id. at 201. 
should seek a different discipline. It is true that universities, as we shall shortly argue, ${ }^{187}$ are becoming more competitive so that they are, to a degree, catering to their customers-students-to a greater extent than they previously have. ${ }^{188}$ Nonetheless, it seems to strain credulity to suggest that the legal professoriate adopts scholarly innovation in an effort to accommodate their students' educational backgrounds. Moreover, the particular pattern of innovations that have stuck in the U.S. legal academy and those that have not does not seem to us amenable to analysis by referring to the (shifting, perhaps) educational backgrounds of law students-a pattern that ought to hold if this hypothesis were correct.

There is an important and clear empirical implication to this hypothesis about the connection between the undergraduate-graduate structure of legal education and the adoption of legal innovations: if countries were to switch their method of legal education from the undergraduate to the postgraduate model, then their receptivity to scholarly innovation ought to increase. So, we might have a prominent test case of this hypothesis as Japan and the Republic of Korea switch their systems of legal education from undergraduate to graduate education. ${ }^{189}$

There may be other factors that we have missed that make U.S. postgraduate legal education particularly open to innovation merely because it is postgraduate education. But our conclusion is that there does not seem to be any clear reason for thinking that legal innovations generally or law and economics in particular will thrive where legal education is postgraduate and languish where it is undergraduate.

\section{Competition in Higher and Legal Education}

Although we have been unable to find much explanatory power in the particular fact that U.S. legal education, almost uniquely in the world, is postgraduate education, we find a great deal of explanatory power in the fact that U.S. legal education is part of a very highly competitive industry while legal education in the rest of the world is not. ${ }^{190}$

187. See infra Subpart IV.D.2.

188. Of course, universities may make accommodation to changing mores by, for example, scheduling fewer early morning classes and more late afternoon classes. The food served in student dining halls has, we are told, changed to keep up with alterations in student taste, and living arrangements within dormitories have also changed to make students feel more comfortable. But these caterings generally become far less flexible when students reach the classroom door. Faculty in nearly every discipline jealously guard their control over classroom and curriculum. See supra note 132.

189. See supra note 175.

190. For fascinating and still relevant historical background on competition in U.S. legal education, see Harry First, Competition in the Legal Education Industry (I), 53 N.Y.U. L. REv. 311 (1978), and Harry First, Competition in the Legal Education Industry (II): An Antitrust Analysis, 54 N.Y.U. L. REv. 1049, 1049 (1979), which argues that the American Association of Law Schools and the American Bar Association "are engaged in an unreasonable restraint of trade." 
Economists find much to admire in competition. Indeed, the beneficent effects of competition is one of the central teachings and tenets of the discipline. ${ }^{191}$ Competition lowers prices, increases quantities available to consumers, maximizes consumer well-being, creates incentives to innovate, and, suitably regulated, minimizes deviations from socially desirable ends. ${ }^{122}$ This is true of markets for both goods and services and applies just as forcefully to the market for legal education as to the market for athletic shoes, bananas, and desktop computers. The central thrust of this part is to argue that competition, in higher education generally and in legal education particularly, is the principal factor in explaining why there is a significant incentive to innovate in legal scholarship in the United States and not in most other parts of the world.

Why would institutions of higher education compete with one another? Presumably for exactly the same reasons that sports teams compete-to win-and that private firms compete with one another-to increase profits and prestige. "Winning" in this context means nothing more elaborate than to do better than one's rivals-to attract a student for which both schools were competing, to persuade a prominent professor to join your faculty rather than someone else's, to rise in the rankings of law schools, to have more resources to do exciting and innovative things, including offering more student scholarships and higher faculty and staff salaries, to attract prestigious conferences, to raise lots of extracurricular money, and so on.

Prestige, a high reputation, follows success in competition, and in the academy prestige is much sought-after. Indeed, one could make a strong case for the proposition that being held in high regard by one's peers is the greatest motivation for many professors. ${ }^{193}$ In contrast to competition among private business firms (where profit plays the central role and prestige plays a smaller role in competition), profit is not so much a direct aspect of successful competition in higher or legal education. Most but not all universities, even those that are fully private, are nonprofit organizations. ${ }^{194}$ And yet having a higher revenue has the great advantage of allowing a law school or university to have higher costs-that is, to spend more money on salaries, scholarships, amenities of the educational process, and so on.

191. See, e.g., MERCURO \& MEDEMA, supra note 47, at 21 .

192. See generally id. at 20-32, 68-93.

193. See generally GEOFFREY BRENNAN \& PHILIP PETTIT, THE ECONOMY OF ESTEEM (2004); James F. ENGlish, The Economy of Prestige: Prizes, AWards, and the Circulation of Cultural VaLUE (2005) (asserting that prestige is often a motivating factor).

194. National Science Foundation, Research and Development Funding and Performance by Nonprofit Organizations, http://www.nsf.gov/statistics/nsf02303/intro.html (last visited Oct. 3, 2007 ). 
In North America competition for prominent and promising law school faculty and for the most talented students is vigorous. ${ }^{195}$ This is, we repeat, because success in this competition has significant payoffs. There are greater resources available for everyone associated with a higher-prestige school, including greater prestige. ${ }^{196}$

A significant factor in signaling success or failure in legal and other university competition is tuition. Students in professional schools in North America pay a significant annual amount in tuition (and, of course, incur substantial opportunity costs in foregoing employment while in school). For example, students at a public law school may expect to pay up to $\$ 15,000$ per year in tuition, and those at a private law school may pay over $\$ 30,000$ per year. ${ }^{197}$ Students and their families should be unwilling to pay these substantial amounts if the education they receive is not worth those fees. To that extent, students are very much like consumers for goods who demand that the items they buy give them greater pecuniary satisfaction than the dollars they surrender in exchange for those items. If students believe that the faculty at a particular law school are famous, that they are good teachers and accessible, and that an education at that law school promises lucrative and exciting employment opportunities, they will gladly pay the tuition in just the same way that consumers gladly part with their money for goods that give them satisfaction.

A law school that is not competing effectively-that is, for instance, falling in the rankings-is one that should have difficulty in attracting prominent and promising faculty, first-rate students, and other resources. Indeed, that school may find that its costs exceed its revenues, that it is losing money in just the same way as does a failing business. Even if the law school is not paying attention to these matters, the university administration may notice this unsuccessful competition and may demand changes to stop the losses (and the subsidization of those losses from central university resources).

In contrast, within most other countries competition among universities for students, faculty, and other resources is muted, if not nonexistent. First and most importantly, there is either no or only a nominal tuition for

195. See, e.g., Yale Law School J.D. Program Brochure, 2008-2009, at 5, 12, available at http://www.law.yale.edu/documents/pdf/Admissions/JD_2009_2.pdf (touting the school's "prominent faculty" and its mission to attract the most "promising students").

196. We are aware that one could make a prima facie case that the competition in legal education is an "arms race" in which competitors spend increasing amounts of money in a vain effort to get ahead of their rivals, only to find that their rivals have spent just as much as have they-making all competitors poorer and no better off vis-à-vis their rivals. For a view that this is what the competition among U.S. law schools for higher rankings may be accomplishing, see William D. Henderson \& Andrew P. Morriss, Student Quality as Measured by LSAT Scores: Migration Patterns in the U.S. News Rankings Era, 81 IND. L.J. 163, 193-97 (2006).

197. American Bar Association, Law School Tuition Average and Median 1985-2005, http://www.abanet.org/legaled/statistics/charts/stats\%20-\%205.pdf (last visited Oct. 4, 2007). 
attending an institution of higher education, including taking an undergraduate major in law. ${ }^{198}$ As a result, the principal cost of attending college or university is the opportunity cost of foregone employment, which means that, all other things equal, the demand for places at institutions of higher education is relatively higher than it is in the United States. Most foreign universities deal with this potential excess demand by strictly limiting-through a numerus clausus-the number of positions open to new students. ${ }^{199}$

A further implication of this divorce from competition and the market in foreign higher education is that administrators there do not have much incentive to put great effort into improving the quality of their institutions. Revenues are often determined by governmental ministries and not by tuitions, gifts, grants, and contracts that vary with the quality of the product provided. ${ }^{200}$ Salaries paid to faculty often are not discretionary and related to scholarly productivity or some other measure of excellence; rather, they are usually centrally determined and tethered principally to age and not to indicia of productivity or excellence. ${ }^{201}$ As a result, particularly productive or accomplished faculty members are paid the same amount as are those faculty members who are not productive or accomplished (whether as teachers, colleagues, or researchers). One might hypothesize that private resources could make up for all these deficiencies but for the fact that nonpublic resources are almost unheard of in foreign universities.

There are several important implications of this great difference between United States and foreign universities. One is that there is almost certainly a net outflow of talented faculty and students-a general "brain drain"-from the rest of the world to the United States. With respect to faculty, the United States is almost unique in the world in the degree to which it is eager to hire talented faculty from anywhere in the world. ${ }^{202}$

198. In early 2004, England's Labor Party proposed to allow English and Welsh universities to charge tuition fees of up to $\$ 5,450$ per year. Aisha Labi, British Proposal to Increase Tuition Meets Opposition from Left and Right, CHRON. HIGHER EDUC., Jan. 9, 2004, http://chronicle.com/daily/2004/01/200401090n.htm. Before, students paid a flat, one-time fee of $\$ 2,050$, and about half of the students receive scholarship aid that obviates that payment. Id. The upper-limit in the proposal was designed to allow some universities for which the demand for entrance was particularly robust, such as Oxford and Cambridge, to charge more than other schools. Id. The plan calls for the fees to be paid only after the student has graduated and his or her annual income exceeds $\$ 27,300$. Id. The proposal has taken effect as of Fall, 2006. See id. See also Higher Education Act, 2004, c. 8, part 3 (Eng.), available at http://www.opsi.gov.uk/acts/acts2004/20040008.htm.

199. See Tony Weir, Recruitment of Law Faculty in England, 41 AM. J. CoMP. L. 355, 360 (1993).

200. See generally H. Bearle \& H. Telford, School Reform and Restructuring, in 9 INTERNATIONAL ENCYCLOPEDIA OF EDUCATION 5275, 5277-78 (Torsten Husén \& T. Neville Postlethwaite eds., 2d ed. 1994); Weir, supra note 199, at 360-61.

201. See Asa S. Knowles, Remuneration: Faculty, Staff and Chief Executive Officers, in 8 INTERNATIONAL ENCYCLOPEDIA OF HIGHER EDUCATION 3565, 3565-77 (Asa S. Knowles ed., 1977).

202. Recall, in Table 3 above, Oren Gazal-Ayal's demonstration that the United States attracts 
Put starkly, there is no "hire American" campaign, either implicitly or explicitly in U.S. institutions of higher education and certainly not in law schools. ${ }^{203}$ In other parts of the world this freedom to hire talented faculty is tightly circumscribed, not just by the fact that U.S. scholars are generally paid more (about which more in a moment) ${ }^{204}$ but also by an emphasis on hiring local talent.

With respect to graduate students, there is and has long been a strong pull exerted by high-quality U.S. research universities on talented students from around the globe. Indeed, by a substantial proportion, the United States attracts a larger number of foreign students than any other country and grants more advanced degrees to foreign students than does any other country. ${ }^{205}$

What does the presence or absence of competition have to do with the incentive to engage in legal innovation? Scholarly innovation is one of the forms that competition among law schools (and universities) takes. Participants in the competitive race strive to innovate in all manner of waysby offering new degree programs, smaller classes, courses on new topics, distance learning, interesting speakers and conferences, and the like. Thus, it would seem that faculty members who are known to be innovative would be highly desirable and sought after by schools that seek to enhance their prestige. So, if a scholarly innovation appears and a faculty member who has fostered that innovation can persuade his or her colleagues of its novelty, nonobviousness, and utility, then the school may use that innovation to attract new students, new faculty, external resources, more interesting outside speakers, and the like.

There is, of course, a problem in identifying which innovations are worth backing and which are not, but that is a pervasive problem in any competitive industry, not just in legal education. A certain amount of risk-

high-productivity scholars from other countries in which they received their original degree. There are not many legal academics on U.S. faculties with foreign law degrees, see ASs'N OF AM. LAW SCHOOLS, supra note 65, at 213-1136, but there seem to be more than there are on European law faculties. As an additional measure of this effect, one might measure the number of Nobel Prize winners who are working in countries other than those in which they were born or educated. Our suspicion is that there are a large number of such faculty in the five academic fields in which Nobel Prizes are awarded and that the vast majority of them are affiliated with U.S. universities. By comparison, there are, we hypothesize, very few U.S.-born academics working in other countries who have won Nobel Prizes while affiliated with foreign universities.

203. This is only slightly disingenuous. In our experience, U.S. law schools would prefer their faculty to have taken a U.S. law degree, but that is not a hard requirement, only a preference.

204. See infra Subpart IV.E.1.

205. But this lead may be shrinking, in part because of the heightened scrutiny of foreign students since September 11, 2001, and in part because foreign universities have begun to compete for the custom of foreign students. See Brains and Borders, ECONOMIST, May 6, 2006, at 15, 15, available at http://www.economist.com/opinion/displaystory.cfm?story_id=E1_GRRNGQS (showing that the United States is fourth behind Australia, Canada, and Switzerland in the percentage of foreign-born graduates in the population and arguing that the United States is losing the competition for foreign graduate students). 
taking is required in following any innovation, and sometimes those who take the risk prosper, and at other times they falter or fail. We have already identified the essential conservatism of most academic disciplinestheir desire to accept change only when the case for doing so is overwhelmingly strong ${ }^{206}$-and one might reasonably conjecture that there is a strong tension between this conservatism and the incentive to innovate. And so there is. But it is precisely that tension that makes legal education in the United States so exciting and, because of its absence, so ploddingly dull in other countries.

There is another tension worth noting in a competitive and, therefore, innovative legal education-the tension, potential or real, between the legal academy and legal practitioners. Some, but not all, scholarly innovations have the effect, largely unintended, of heightening differences between legal academics and the practicing bar. To a large degree, practitioners are willing to delegate to law professors the determination of the content and process of legal education. But there are limits to that delegation, and some innovations may cross over those limits. Judge Harry Edwards, once a distinguished law professor, has drawn attention to what he calls a "growing disjunction" between what is being taught in law schools and what is valuable to practitioners. ${ }^{207}$ Without commenting on whether this disjunction is real and growing (we believe that it is both), we simply raise this matter to suggest that where the practicing bar's control over legal education is stronger, the weaker is the ability of law professors to innovate in ways that seem to be of little use to practitioners. As a corollary, we assert that the more vocational in nature and quality is legal education, the less likely is it to be innovative. A legal educational industry whose self-justification is principally the creation of more lawyers will have no more incentive toward scholarly innovation than will automobile-driving schools.

The considerations of this part suggest some additional empirical hypotheses. The most obvious of these is the contention that the more competitive the higher education or legal education sector becomes, the greater the incentive will be to innovate, including to innovate in scholarship. One might believe, for example, that as the European Union continues to liberalize its education sector, legal education in the twenty-seven nations of the Union may become vigorously competitive, particularly to the extent that there is a continuing easing of restrictions on practicing law in countries other than the one in which one is educated or originally licensed. Additionally, as the international competition for law professors increases, as it appears to be doing, the incentive toward scholarly innovation will

206. See supra text accompanying notes 138-142.

207. Harry T. Edwards, The Growing Disjunction Between Legal Educotion and the Legal Profession, 91 MICH. L. REV. 34, 34-36 (1992). 
increase. Somewhat paradoxically but explicably, we also predict that as the degree of public support for higher education, including legal education, falls, the incentive to compete will increase and with it, so, too, will the incentive to innovate. To take but one example, there is today in Germany only one private law school-Bucerius in Hamburg; all others are state (land) institutions that take students largely from their respective states (lander) ${ }^{208}$ Imagine the pressures to innovate that will be exerted on the German state institutions if the private school prospers.

\section{E. The Treatment of the Legal Professoriate}

The factors on which we focused in the previous part were drawn with a very broad brush. Although we mentioned the effects of competition for high-profile professors as being an important factor in explaining the incentive to innovate, we did not mention other aspects of the lives of professors that might have an important effect on the incentive to innovate. Here we want to elaborate on some of those aspects, drawing particular attention to institutional differences between the lives of law professors in the United States and the rest of the world that might help to explain the differences in receptivity to legal innovation.

\section{Tenure and Legal Publications}

In the United States, law professors are expected to engage in original, high-quality scholarship about legal topics. ${ }^{209}$ During their first several years in the academy, law professors seek to establish a record of scholarship so that at some point between their fourth and six years in the profession, their colleagues will seek to convert their appointments from a probationary to a more permanent status. ${ }^{210}$ Although most research universities in the United States insist that teaching and public service will count as much or nearly as much as will scholarship in making this determination, the central determinant of the promotion decision will be a solid record of original scholarship. ${ }^{211}$

In addition, U.S. law professors publish their scholarship in law reviews that are nearly all edited and managed by third-year law students. ${ }^{212}$

208. See Stefan Korioth, Legal Education in Germany Today, 24 WIS. INT'L L.J. 85, 90-91 (2006).

209. Association of American Law Schools, AALS Handbook: Statement of Good Practices, http://www.aals.org/about_handbook_sgp_eth.php (last visited Oct. 16, 2007).

210. See, e.g., UNIV. OF ILL., REPORT ON THE UNIVERSITY OF ILLINOIS, SEMINAR ON TENURE (1999), http://www.vpaa.uillinois.edu/reports_retreats/tenure_seminar_document.asp?bch=0 (quoting William Van Alstyne, professor of law at Duké University).

211. See id.

212. See Richard A. Posner, Against the Law Reviews, Legal AfFaIRS, Nov.-Dec. 2004, at 57, available at http://www.legalaffairs.org/issues/November-December2004/review_posner_novdec04.html. 
In contrast, most foreign law professors experience far less pressure to publish original scholarship than do U.S. law professors, and where they are expected to publish, the principal outlets are those for practitioners. ${ }^{213}$ Also, most law reviews outside the United States are not edited by students but by practitioners or by established law professors. ${ }^{214}$

Might these two differences between the United States and the rest of the world help to explain differences in the receptivity to law and economics and other scholarly innovations? Certainly. Let us assume, as seems reasonable, that student-edited law reviews are more open to innovation and less tied to the practice of law than are legal publications edited by practitioners or by established law professors. And let us further assume that a professoriate that must produce original scholarship in order to prosper generally tends to produce more original scholarship and more innovative scholarship than a professoriate that faces either no or a light publication requirement or that must prudently appeal to the established professoriate in order to be published in outlets controlled by those older faculty. Those two assumptions guarantee the result that the promotion and publication incentives facing U.S. law professors are bound to result in more original scholarship and, therefore, more openness to legal innovation than is the case in the rest of the world.

The U.S. system is set up to encourage publication maximization. ${ }^{215}$ Therefore, scholars identify legal innovations, such as law and economics, as a gold mine opportunity for new topics (theoretical and empirical) that could be used by capable individuals to enter the market for ideas and scholarship. In other countries the culture of publication is not so strong, hence less demanding on the identification of new topics.

We should not neglect a point that is important, the use of English as the language of science. Until recently, neither the older, well-established European law professors nor their law students had the time, the inclination, or the incentive to learn or enhance their English skills, thus making access to the law-and-economics literature (or more importantly, substantively contributing to the literature) much more difficult (indeed, with respect to the latter, almost impossible). The civil law courses are, of course, taught in their country's language; and if they were going to practice law in their country or pursue a national academic path, enhancing their English skills simply did not make sense given the high marginal opportunity costs. This situation has begun to change. ${ }^{216}$

213. See Dau-Schmidt \& Brun, supra note 113, at 115 .

214. See id.

215. See id.

216. Since at least the 1970 s English has been almost universally recognized as the scholarly language of economics. See Frédérick Charette, Law and Economics in Quebec, in 1 ENCYCLOPEDIA OF LAW AND ECONOMICS 318, 319 (Boudewijn Bouckaert \& Gerrit De Geest eds., 2000), available at http://encyclo.findlaw.com/0370book.pdf. A trend toward universal English seems to be happening 


\section{Compensation for Law Professors}

A very important aspect of the legal academic market in the United States that differentiates it from legal academics in other countries has to do with salary and the terms and conditions of employment. Briefly put, college and university professors in the United States are relatively strictly isolated from market activity (outside the academy). For example, by university statute, legislation and the like, U.S. professors are typically supposed to limit their outside consulting activity to one day per week during the academic calendar year, ${ }^{217}$ which usually runs from early September through early May. ${ }^{218}$

For law professors in the United States the upshot of this restriction is that there is a relatively strong wall separating the practice of law from the practice of being a legal scholar. There are very, very few U.S. law professors who work part-time as attorneys and part-time as law professors. One is usually full-time in one profession or the other. There are, of course, notable exceptions to this blanket statement. First, law schools have adjunct law professors-practitioners who teach, usually, a single course per academic year in their professional specialty. ${ }^{219}$ But as valuable as their contribution to the educational enterprise in the legal academy may be, they are not judged according to the same criteria as are full-time law professors. Second, a full-time law professor who finds that his or her consulting work is beginning to demand a greater share of time than that allowed by the university's customs or rules will often experience pressure to leave the academy-temporarily, perhaps-to finish the consulting opportunity. ${ }^{220}$ Failing to do so may result in her administration's putting pressure on her either to stop the consulting or to resign from the profes-

within law and economics but not yet within legal scholarship more broadly. Within the European Union, English is becoming the default language for legal work with the Commission and its Directorates. Jo Shaw, The European Union: Discipline Building Meets Polity Building, in THE OXFORD HANDBOOK OF LEGAL STUDIES, supra note 86, at 325, 333-35. An immediate consequence of these differences is that there are now numerous rankings of European economic departments and even international rankings concerning the quality of research, but there is no European or international ranking of law schools (with the notable exception of the ranking produced by SSRN but of serious limitations). Pantelis Kalaitzidakis, Theofanis P. Mamuneas \& Thanasis Stengos, RaNkINGS of ACADEMIC JOURNALS AND INSTITUTIONS IN ECONOMICS 5-11 (2001), available at http://www.le.ac.uk/economics/research/rankings/eearank.pdf.

217. See, e.g., Penn State-Human Resources, Policy HR80 Private Consulting Practice (Feb. 3, 2006), http://guru.psu.edu/policies/OHR/hr80.html ("a faculty member may engage in consulting up to four days per month during his/her appointment period").

218. Professors are nominally free to spend all of their time during the non-academic calendar consulting, although many are paid by their college or university employers during that period. Most choose to spend their summers doing research and writing.
219. See, e.g., Georgetown Law, J.D. Adjunct Faculty, http://www.law.georgetown.edu/faculty/list.cfm?Type =JDAdjunct\&Letter =A (last visited Oct. 22, 2007).

220. See supra note 217. 
soriate. These matters are all subject to exceptions. Nonetheless, as a general matter, U.S. university professors in all fields, including law, are expected to be researchers, teachers, and colleagues first and foremost and to keep their outside business interests to a minimum. ${ }^{221}$

This strong limitation on outside employment has the inevitable result of making the compensation of U.S. law professors very handsome-not, surely, as handsome as the compensation that the professor could earn in the full-time practice of law but still handsome by comparison to the average compensation level in other disciplines within the university. ${ }^{222}$ The simple fact is that if U.S. law professors were not paid a high salary, they would be more inclined either to continue practicing law, rather than coming full-time to the academy, or to work part-time as an attorney to supplement the inadequate or unsatisfying university compensation.

The result of this bargain between U.S. law professors and their universities is that the professors are expected to look like other university professors more than they look like practicing lawyers. ${ }^{223}$ Although it is very rare to have the terms of this bargain made explicit, the gist of it is that U.S. universities expect U.S. law professors to be researchers, teachers, and public servants first and foremost. ${ }^{224}$ And therefore, U.S. universities expect law professors in their role as researchers to aspire to the same general indicia of quality and quantity as do their peers in physics,

221. See supra note 217 ("The faculty member's first duty and first responsibility is to the University. Outside service should not be undertaken, whether with or without pay, that might interfere with the discharge of this paramount obligation."). These walls separating the academy and practice are thinnest in the professions. In medicine, for instance, one could sensibly argue that a professor who had never practiced and did not continue to practice surgery should not teach that subject to others. One used to hear similar things said in U.S. law schools-namely, that professors who had not practiced in the area of insurance law should not teach insurance law. But that connection seems to us to hold less force than it did, say, twenty years ago.

222. Faculty Salaries Up 3.8\%, INSIDE HIGHER ED, Mar. 12, 2007, http://www.insidehighered.com/news/2007/03/12/cupa ("Across all sectors, a full law professor earned an average of $\$ 121,301$-almost $\$ 50,000$ more than a full professor of English on average. The average salary earned by a new assistant professor of engineering of $\$ 69,510$ is almost $\$ 20,000$ more than the average for a new assistant professor of education.").

223. As noted, most universities recognize that professors of medicine will be more effective as instructors and researchers if they continue to practice medicine-to a degree. But we do not observe U.S. universities insisting that professors of social work, professors of education, professors of journalism, professors of business administration, professors of engineering, and other professors in professional schools continue to have an explicit practice component in addition to their scholarly responsibilities. On the other hand, we regularly see professors of drama, dance, and other fine arts continue to perform as they teach. We do not recognize in this pattern of sometimes forbidding and sometimes requiring continuing contacts with one's profession a coherent philosophy. For a general discussion of "[t]he [c]hanging [c]omplexion of [f]aculty [w]ork," see JACK H. SCHUSTER \& MARTIN J. FINKELSTEIN, THE AMERICAN FACULTY; RESTRUCTURING OF ACADEMIC WORK AND CAREERS 75124 (2006).

224. See Univ. of Richmond, Faculty HandBook $\S$ VI.A (listing, as "Standards and Procedures for Reappointment, Promotion, and Tenure" three criteria: "Teaching . . Scholarship . . . Service"). 
art, anthropology, medicine, and so on. That is, U.S. universities expect law professors to be innovative, to be leading scholars in their fields.

In contrast, law professors in the rest of the world are typically not paid at the same level as are U.S. law professors. ${ }^{225} \mathrm{We}$ are not certain whether the central reason for this is a desire to economize on law-school salaries-tacitly encouraging continued practice by professors by paying them a fraction of what they make as attorneys-or a conscious desire to maintain a close connection between what is taught and what is practiced or both. Whatever the reasons, the implication is that in most countries other than the United States, law professors also practice law. As a result, foreign law professors have far less time than do U.S. law professors to devote to original scholarship. So, even if foreign law professors had a strong desire to innovate as scholars, they might not have time to do so. Nor are they likely to be rewarded for doing so, as we have already seen. ${ }^{226}$

An additional and probably unintended consequence of this foreign penury in paying law professors (or in failing to forbid their continuing practice) is that there is likely to be a much closer connection in countries other than the United States between legal educators and practicing lawyers. This inevitably means that the vocational aspects of legal education dominate the scholarly aspects. Moreover, the ability-for better and worse-of U.S. law professors to stray from the immediate oversight and demands of the practicing bar and to experiment with all sorts of scholarly innovations is simply not available in those foreign countries where law professors continue to practice law.

There is a clear empirical implication of these observations. If other countries adopt the U.S. practice of discouraging their legal educators from practicing law and compensate them sufficiently so that they opportunity cost of not practicing is low, then scholarly innovation will increase in those countries, all other things held equal.

\section{F. Utilitarianism versus Kantianism}

Some commentators point to a more thoroughgoing but less precise difference between the United States and Europe as being central in explaining the difference between the two areas in their receptivity to law and economics. ${ }^{227}$ Legal scholars in Europe, they say, are part of a Kantian tradition that, to do perhaps actionable violence to that tradition, holds that legal rights and responsibilities are absolute or nearly so, not contingent on shifting circumstances or subject to balancing tests. In contrast,

225. See Weir, supra note 199, at 360-61.

226. See supra Subpart IV.E.1.

227. See, e.g., Dau-Schmidt \& Brun, supra note 113, at 610-20. 
U.S. (and perhaps other nations') legal scholars are imbued with a utilitarian, consequentialist, or pragmatic tradition that places importance on balancing, on law's real effects, and not just on immutable truths. ${ }^{228}$

On this understanding, utilitarianism implies a thoroughgoing costbenefit analysis applied to legal issues. Importantly, that would seem to suggest that there are no legal rights that are beyond that calculus. Rather, they are all contingent and subject to weakening, strengthening, revocation, and nonenforcement depending on period-to-period changes in costs and benefits. ${ }^{229}$ So, the argument continues, Europeans are reluctant to incorporate law and economics into their legal analyses because that innovation seems to necessitate shifting along the spectrum toward utilitarianism and away from Kantianism. ${ }^{230}$

We do not know what to make of this point. If utilitarians and Kantians do, in fact, have these distinct points of view; if it is accurate to say that there are far more utilitarians than Kantians in the United States and far more Kantians than utilitarians in Europe; and if, finally, subscribing to utilitarianism as a guiding principle is a precondition for finding value in law and economics, then the point may have explanatory force. However, we are not certain of the truth of any of these assertions.

First, we are not adept enough in jurisprudence to evaluate the claim about the relationship between utilitarianism and Kantianism. Second, we are not aware of any empirical evidence that suggests that U.S. law professors tend to be utilitarians while European law professors tend to be Kantians. Perhaps they do. We simply do not know. Third and finally, we are skeptical of the claim that finding value in law and economics and a belief in noncontingent legal rights are incompatible. To take a sample of two, we both find a surface plausibility in the assertion that some rights are more important than others and that there are legal rights that are more contingent than others.

\section{G. Legal Realism}

In our discussions with law professors around the world about law and economics, we have noticed that U.S. law professors are far more likely to be concerned with the real effects of law on targeted behavior than are law professors in Europe (and elsewhere). Put baldly, U.S. law professors

228. See, e.g., id. at 608-09. See also Kristoffel Grechenig \& Martin Gelter, The Transatlantic Divergence in LegaL Thought: American Law and Economics vs. German Doctrinalism, 31 HASTINGS INT'L \& COMP. L. REV. 295, 296 (2008).

229. There is nothing inherent in this understanding of utilitarianism that precludes demanding a stronger showing of costs over benefits-a "clear and convincing" standard, as it were-for changes, such as weakening the enforcement of certain rights.

230. This is the central thrust of Dau-Schmidt and Brun's argument about why Europeans are slow to adopt law and economics. See Dau-Schmidt \& Brun, supra note 113, at 610-19. 
seem far more willing to reform any given law upon a showing that the law is not having its intended effect or is having an undesirable unintended effect than are professors in Europe. Let us characterize this concern with the actual or consequent effects of law as "legal realism."

Legal realism became an important scholarly innovation in U.S. law schools in the 1920s and 1930s, largely as a reaction to the formalism that had characterized the first half-century or so of the academic study of law. ${ }^{231}$ For a host of reasons, some of which may have to do with an essential and distinguishing aspect of U.S. culture, legal realism became a core part of the U.S. way of looking at law. ${ }^{232}$

By contrast, realism in this sense has never caught on among European law professors. ${ }^{233}$ Professor Hans-Bernd Schäfer of the Faculty of Law at the University of Hamburg has suggested that one strong reason that legal realism has not caught on in Europe is its history. ${ }^{234} \mathrm{~A}$ form of legal consequentialism appeared in Germany in the late nineteenth and early twentieth centuries, fostered mostly by sociologists, not lawyers, and was adopted by the German Imperial Court after $1890 .^{235}$ Professor Schäfer contends that the court practiced consequentialism and realism, interpreting controversies not formalistically but so as to further clear and widely shared social goals. ${ }^{236}$ The National Socialists then adopted the same consequentialist legal philosophy but used it to further their particular goals. ${ }^{237}$ The result was a discrediting of realism and consequentialism. To protect law from being enlisted in the service of ideologues, German (and other European) courts after World War II retreated to a culture of judicial modesty and formalism. ${ }^{238}$ Other forms of realism were associated with a Marxist sociological view of law that sought to gain a foothold in European law in the 1960s but were discredited. ${ }^{239}$ The same criticisms that led to the general decline of Marxism as an academic field of study also led to the decline of a realist jurisprudence-at least in Germany. ${ }^{240}$ The strong gravitational pull of the late nineteenth and early twentieth cen-

231. For an overview, see generally Neil Duxbury, A Century of Legal Studies, in THE OXFORD HANDBOOK OF LEGAL STUDIES, supra note 86 , at 950 , 950-74.

232. Id. at $950-58$.

233. See id. at 950-51. The observation that there was no legal realism revolution in Europe does not mean that there was no legal realism in Europe. It simply means that legal realism failed to influence legal thinking to the extent that it did in the United States.

234. See Hans-Bernd Schäfer, What are the Practical Implications of Law and Economics Research in Germany?, in NEW FRONTIERS IN LAW AND ECONOMICS 193, 196-97 (Peter Noble \& Marina Gets eds., 2006).

235. Id. at $195-96$.

236. See id.

237. See MÜLLER, supra note 20, at 6-35.

238. See Schäfer, supra note 234, at 194.

239. See id. at 195-99.

240. See id. 
tury formalist systematizers of the civil law reasserted itself after this brief flirtation with realism.

Professor Schäfer argues that legal realism has, as a result of this history, been rejected by many European scholars. ${ }^{241}$ But he also believes that this reluctance to consider law's consequences in evaluating law is now dissipating. ${ }^{242}$

What is the connection between legal realism, as we have characterized it, and receptivity to law and economics specifically and legal innovation generally? As to openness to innovation generally, there is nothing particular to be gained in looking at the failure of legal realism to gain a foothold in Europe. Whatever explanatory power that the factors we have already examined might contribute to assessing that failure will surely play a role in explaining this particular failure to adopt an innovation. To that extent, the particular success or not of legal realism does not contribute to a general understanding of the market for legal innovation.

But with respect to law and economics, the history of legal realism may contribute a great deal. Legal realism is a form of consequentialism, the view that the consequences of laws (and not just their justifications or formal coherences) matter in their evaluation. ${ }^{243}$ And to a great degree law and economics is the grand culmination of legal consequentialism (at least so far) in that it provides a comprehensive and coherent method of hypothesizing about and evaluating the real effects of law on targeted behavior. One might speculate that the attractiveness of law and economics to U.S. law professors arises precisely from its ability to provide the most satisfying method of talking about legal consequentialism (on the understanding that for many decades all or nearly all U.S. law professors have been consequentialists).

There may be other reasons to embrace law and economics, independent of its connection with legal realism. But to the extent that there is a strong connection between a widespread consequentialist view of the law and law and economics, then we might assert that a prior, successful legal realist scholarly innovation is a sufficient (but not a necessary) condition for the later adoption of law and economics.

Even if there is an intuitive plausibility to this connection between legal realism and law and economics, it is not, by itself, enough to explain widespread differences in the acceptability of scholarly innovations in law. A particular problem with this explanation is that it simply pushes the question back to trying to explain why the United States had a legal realist revolution and Europe did not. And in explaining that we are thrown back

241. See id. at 197.

242. See id. at 193-96.

243. See Leiter, supra note 22 , at $50-53$. 
on the factors that we have already investigated in the parts above and in those to follow. ${ }^{244}$

\section{H. The Great Man or Woman Theory}

Another theory that we sometimes hear is that law and economics has prospered in North America because it has been championed there by a great man or woman or by great men or women. There are various candidates who are mentioned for this role, at least with respect to law and economics-Ronald Coase, Guido Calabresi, Henry Manne, and Richard Posner-all of whom have a valid claim to the position. The argument is that in any given time period there are many scholarly innovations, only a few of which survive. Those that survive typically have a noteworthy champion who, even if he or she was not the originator, has recognized the value of the innovation and has thrown his or her prestige and entrepreneurial abilities behind it. That champion may have taken the time and effort to organize the scattered sticks and branches of the innovation into a coherent whole, thereby allowing others to see the innovation in its entirety and, not unimportantly, enabling others to teach the new material.

Judge Richard A. Posner fits this model well. His Economic Analysis of Law, now in its seventh edition, defined the field in the 1970s and 1980 s and was the only text to which those eager to teach the material could turn. ${ }^{245}$ The clarity and power of his writing and thought commanded attention, if not wholehearted agreement, and spurred others to scholarly efforts to fill in gaps in Posner's presentations. ${ }^{246}$ The volume and range of his scholarly writings were so great and wide that he almost single-handedly pushed economic analysis into every corner of the law. He helped to found the Journal of Legal Studies, one of the principal outlets

244. Some scholars of the University of Chicago approach to law and economics suggest that the literature on the efficiency of the common law bears more than a passing resemblance to doctrinalism and, in certain respects, functions as an attempt by the Chicago school to return to formalism and to autonomous legal thought that is unified by an underlying economic logic. See Richard Posner, The Present Situation in Legal Scholarship, 90 YALE L.J. 1113, 1115, 1120 (1981). On realism's influence on law and economics (contra Posner's view that it was inconsequential for law and economics), see Steven Medema, Wandering the Road from Pluralism to Posner: The Transformation of Law and Economics, in Symposium: From Interwar Pluralism to Postwar Neocolonialism, 30 HisT. POL. ECON. 202, 204-08 (Mary Morgan \& Malcolm Rutherford eds., Supp. 1998), and Steven G. Medema, From Dismal to Dominance? Law and Economics and the Values of Imperial Science 23-33 (May 12, 2006) (unpublished manuscript), available at economix.u-paris10.fr/pdf/seminaires/H2S/Medema.pdf. For the view that legal realism played no role in the history of the rise and adoption of law and economics, see Charles Rowley, An Intellectual History of Law and Economics: 1739-2003, in THE ORIGINS OF LAW AND ECONOMiCS: EsSAYS BY THE Founding Fathers 3-32 (Francesco Parisi \& Charles K. Rowley eds., 2005).

245. See, e.g., Richard A. POSNer, ECONOMiC ANALYsis of Law ix-xi (1973); Richard A. POSNER, ECONOMIC ANALYSIS OF LAW xix (3d ed. 1986).

246. See, e.g., Richard A. Posner, ECONOMic ANAlysis of LAW xvii (2d ed. 1973). 
for high-quality scholarship in the area. ${ }^{247}$ And in 1981 he was elevated to the federal judiciary and has served for many years as the Chief Judge of the United States Court of Appeals for the Seventh Circuit. ${ }^{248}$ In these and other ways, Judge Posner might be said to have breathed life into law and economics and made it a vital part of modern legal scholarship.

The implication of this view, if it is correct, is that Europe (and the rest of the world) will not have scholarly innovations unless they, too, have great men or women who champion them. One possibility that seems remote is that other nations will allow the scholarly champions from North America also to serve as their national champions. So, Judge Posner could, where he so inclined, take his campaign to foreign venues and foster acolytes there. But typically, one needs a home-grown champion, someone with stature in the appropriate scholarly and professional circles to warrant a close look by potential domestic adopters. If such local champions have failed to appear for law and economics (and other scholarly innovations), the question then becomes, "Why have such champions appeared in North America but not elsewhere?"

We do not want to heap too much criticism on the "great man or woman" theory because we believe that there is a kernel of truth to it. But we do have some criticisms. First, we have already laid out our view that scholarship is not like commercial merchandise: one cannot make scholars adopt innovations through a glitzy marketing campaign or steep price discounts. Over the long run scholars almost never adopt innovations that are wrong or unproductive, no matter who is urging them to do so. ${ }^{249}$ Scholarship is subject to a rigorous test applied independently by thousands of practitioners learned in the field. Even if an incorrect or unproductive innovation were to bedazzle a generation of scholars, a subsequent generation would find the flaws in the innovation and lead the profession back to solid ground. ${ }^{250}$

The import of this point is that if an innovation has commanded a widespread consensus as valuable in a competitive scholarly discipline, then it probably-but not certainly-has something to be said for it. A champion can give an innovation a push, but he or she cannot sustain its momentum single-handedly or in the face of widespread skepticism or outright opposition. Others must help. And not just a few, but a large

247. See Additional Activities, Richard A. Posner, http://www.law.uchicago.edu/faculty/posnerr/activities.html (last visited Oct. 16, 2007). See generally Journal of Legal Studies Homepage, http://www.journals.uchicago.edu/JLS/ (last visited Oct. 16, 2007).

248. Curriculum Vitae, Richard A. Posner, http://www.law.uchicago.edu/faculty/posner-r/cv.html (last visited Oct. 16, 2007).

249. See supra Subpart IV.B.

250. This is one of the important implications of Imre Lakatos, Falsification and the Methodology of Scientific Research Programmes, in CRITICISM AND THE GROWTH OF KNOWLEDGE 91, 91-188 (Imre Lakatos \& Alan Musgrave eds., 1970). 
number, a significant percentage of those working in the field. The remarkable thing about law and economics is how many legal scholars (and how many remarkably talented people) have helped to push it forward.

We have already spoken of our strong sense that there is an inertia or conservatism about many scholarly disciplines, keeping them in wellestablished paths. ${ }^{251}$ After all, the scholarly life is comfortable once one has mastered the materials that constitute the core tools of the profession. Scholars, like almost everyone else, do not like to be forced from those comfortable and established ways. And that is precisely what innovations do: they require scholars to rearm themselves and to do battle against those who would criticize older methods and conclusions. ${ }^{252}$ We reiterate our earlier point that any scholarly innovation must overcome a strong presumption against it. ${ }^{253}$ If that is so, then those innovations that survive have done so by surmounting a formidable series of obstacles placed in their ways. The broader audience (beyond those already converted) was skeptical; heroic efforts were necessary to convince them that the innovation is worth following.

Finally, there is an aspect of the "great man or woman" theory that may, in fact, interfere with the widespread adoption of a scholarly innovation-the fact that the innovation may become overly identified with the work of its champion. Our perception is, for example, that Judge Posner has assumed, among some critics or skeptics of law and economics (but, importantly, not among law-and-economics scholars), a papal role: his pronouncements on the economic analysis of law are taken to be ex cathe$d r a$, infallible, and the voice of the profession. Law and economics, to these critics, is akin to a religious belief to which one subscribes by faith or not at all. Those who take issue with the leader's analyses are thought to be in danger of excommunication. Not much learning is required of devotees. Rather, they simply master a few holy texts, incorporate predictable phrases such as "efficiency," "transaction costs," "collective action," and "externality" and are thereby re-born as scholars. As a result, for those who hold this preposterous view, one can criticize the entire corpus of law and economics by criticizing the work of Judge Posner.

But the truly significant fact about the field is that it has grown far beyond the work of one remarkable scholar or small group of scholars. No one person and certainly no committee of people serves to authenticate

251. See supra text accompanying notes $138-142$.

252. Judge Posner argues that there is a tendency for younger scholars in any field to adopt new methods as a means of making their way against the older, established scholars in the field. This tendency is clearly in tension with the desire of younger scholars to follow in the footsteps of those who will be judging them. As Max Planck is sometimes alleged to have said, "Science advances funeral by funeral." See NEW FRONTIERS IN LAW AND ECONOMICS 4 (Michael Szenberg \& Lall Ramrattan eds., 2004).

253. See supra text accompanying notes 138-142. 
views as being true "law and economics"; those who profess law and economics are a diverse group among whom there are different styles, controversies, and emphases. Whatever it is that may account for the rapid rise of law and economics in the United States and its slow reception in Europe and the rest of the world, it is not the presence or absence of formidable individual national champions.

\section{Legal Culture}

We have already alluded to the possibility of a general cultural disposition toward utilitarianism, competition, and consequentialism that may help to explain the adoption of legal innovations generally and law and economics particularly. ${ }^{254}$ In this part we want to explore very briefly the possibility that there is a particular legal culture that plays a leading role in these matters. By "legal culture" we adopt the view of Merryman and Clark, who define those words to mean "those historically conditioned, deeply rooted attitudes about the nature of law and about the proper structure and operation of a legal system that are at large in the society." 255 A legal culture embodies more than the customs and behavior of those who work in and think about the law. It also reflects more general cultural attitudes and so may incorporate some of the more general dispositions that we have noted in previous parts.

Assuming that legal cultures are real and different across countries (or, possibly, families of legal systems), then these cultures may help to explain differences in amenability to legal innovation. For example, cultures may resist transplants from other cultures in the same fashion that the human body resists organs transplanted from other humans or other species. Suppose, as is reasonable, that law and economics (and many other innovations) are perceived by those outside the United States as quintessentially American products. Other legal cultures may reject that transplant solely on the ground that it is an American transplant. However suitable it may be to the American legal culture, it is not at all suitable, they argue, for foreign legal cultures.

On the basis of their experience in France, Ken Dau-Schmidt and Carmen Brun argue that this is precisely why the French and Germans have been reluctant to have anything at all to do with law and economics. ${ }^{256}$ They argue that law and economics embodies American individualism against the French social contract and the German concern for fairness and equity. ${ }^{257}$

254. See supra Subpart IV.D.

255. JOHN HENRY MERRYMAN \& DAVID S. ClaRK, COMPARATIVE LAW 28 (1978).

256. See Dau-Schmidt \& Brun, supra note 113, at 605-14.

257. See id.; see also discussion supra note 121. 
There may be something to this view, but we are dubious. First, the rejection of law and economics in France and Germany does not appear to be as violent, life-threatening, or traumatic as is that of the human body to an alien organ transplant. There seem to have been some small successes in both France and Germany. It is the central thrust of this Article that there is a limit to these successes until some other conditions prevail, but, on the other hand, we think that it goes too far to say that innovative transplants are doomed to failure.

Second, in France, Germany, and elsewhere there have been successful transplants between the United States and those countries in other academic disciplines. If there were a distinctive medical or economic culture, as there is alleged to be for law, then one would expect there to be resistance to U.S. innovative transplants in those other areas. But there have not. Moreover, there have been some significant French and German transplants from those other academic disciplines into U.S. academic disciplines. To take but one example, consider the many contributions made by the economists Edmond Malinvaud and Jean Tirole to our understanding of economics. ${ }^{258}$

There is another sense in which legal culture may play a role in precluding innovations from other countries. Professor Anthony Ogus has elaborated Merryman and Clark's definition of legal culture to include "a combination of language, conceptual structure and procedures, constitut[ing] a network which, because of the commonality of usage, reduces the costs of interactive behaviour." 259 Therefore, a legal culture in Ogus' sense may serve the economic function of reducing the costs of resolving disputes.

But Ogus stresses that there is a potential social cost to legal culture..$^{260}$ Formalism and complexity may make the law inaccessible to all but experts, thereby creating a monopolistic position for those who can navigate the formalities and rituals of the system. ${ }^{261}$ The legal culture may, therefore, be exploited by a "dominant group with monopoly power," thereby generating economic rents for that group and raising the general price of legal services. ${ }^{262}$

This pessimistic view of the legal culture might make common cause with a view that we raised earlier in which practicing lawyers keep tight

258. See, e.g., Edmond Malinvaud, Capital Accumulation and Efficient Allocation of Resources, 21 ECONOMETRICA 233 (1953); Eric Maskin \& Jean Triole, A Theory of Dynamic Oligopoly, I: Overview and Quantity Competition with Large Fixed Costs, 56 ECONOMETRICA 549 (1988).

259. Anthony Ogus, The Economic Basis of Legal Culture: Networks and Monopolization, 22 OXFORD J. LEGAL STUD. 419, 420 (2002).

260. Id. at $425-29$.

261. Id. at $427-29$.

262. Id. at 420 . 
control on law schools so as to tamp down competition. ${ }^{263}$ So, to the extent that scholarly innovation threatens the group that is enjoying monopolistic returns in the practice of law, that group will have a strong incentive to stifle scholarly innovation. The failure to adopt innovation in Europe and elsewhere is simply, on this account, part of an anticompetitive strategy to realize supra-competitive returns in the practice of law.

There may be something to this view. U.S. law firms, for example, are notoriously more aggressive and competitive than are many foreign law firms, suggesting that they are comfortable with zealous competition in the provision of legal services. ${ }^{264}$ That is, a competitive domestic market for legal services may be an important causal factor in explaining the receptivity of legal educators to innovation in legal scholarship. ${ }^{265}$

An important implication of this view of the role of legal culture is that the spread of competition in legal services across national boundaries-the globalization of legal services-may have a liberating effect on scholarly innovation in law. As international markets open up and law firms move across jurisdictions and courts accommodate more liberal choice-of-law rules or principles of mutual recognition, the monopolistic grip of national legal cultures is bound to loosen. ${ }^{266}$ Ogus predicts that "as the volume of international transactions relative to purely domestic transactions increases, so also will the benefits of adapting the [legal culture's] specifications sets, since adaptation will become (relatively) cheaper. As a consequence, the monopolistic characteristics of the domestic legal culture will be threatened. ${ }^{267}$

\section{J. Informational and Reputational Cascades}

In a recent article, Professor Cass Sunstein has brought some of the insights of behavioral law and economics to the study of scholarly innovations. ${ }^{268} \mathrm{He}$ hypothesizes that the appearance, spread, and disappearance or success of legal scholarly fads and fashions might be profitably ex-

263. See supra Subpart IV.F

264. See generally MACKLIN Fleming, LAWYers, Money and SUCCESS: THE CONSEQuences of DOLLAR OBSESSION 83-90, 113-128 (2002).

265. This is a testable proposition. Our model in the following part makes a formal connection between a competitive market for legal services and innovation in legal scholarship. See infra Part V.

266. See Ogus, supra note 259 , at $420-21$.

267. Id. at 431-32.

268. See Sunstein, supra note 125 , at 1251-64. 
plained by the phenomena of informational and reputational cascades ${ }^{269}$ and group polarization. ${ }^{270}$

Suppose that a young scholar joins the faculty at the University of West Jefferson School of Law. In defining what positions she will take on controversial issues in the law and what scholarship she will pursue, she naturally looks around her to take guidance from those nearest to her and from those who strike her as learned in the law. ${ }^{271}$ If a large number of her colleagues seems to find textual interpretation of the U.S. Constitution a viable method of deciding contested issues in constitutional law, she may adopt that style of interpretation. If she makes decisions about whether to follow a law-and-society or law-and-economics method of scholarly investigation and relies on the reputation of the other scholars whom she admires and who will be evaluating her scholarly progress for the purposes of tenure and promotion, she may be inclined to tilt toward the particular style that has greater strength or standing at West Jefferson. ${ }^{272}$ If most young scholars behave in that fashion, then institutions and entire professions, Sunstein argues, could gravitate toward particular points of viewalmost independently of any intrinsic merit of those points of view. ${ }^{273}$

The thrust of this hypothesis is that in educational institutions these informational and reputational cascades will drive an increasing percentage of a faculty toward particular points of view so that those views-there is no need that only one prevails-are dominant at that school.

In addition, Sunstein invokes the phenomenon of "group polarization" as a further explanation for scholarly fads. ${ }^{274}$ When a group with similar beliefs-say, a group of people who hold conservative political beliefsmeets to discuss politics, they tend to gravitate toward the most extreme views within that group. ${ }^{275}$ This force exacerbates the force of an informa-

269. See $i d$. at 1251-52. On the economics of informational cascades, see generally Sushil Bikhchandani, David Hirshleifer \& Ivo Welch, A Theory of Fads, Fashion, Custom, and Cultural Change as Informational Cascades, $100 \mathrm{~J}$. POL. ECON. 992 (1992), and Sushil Bikhchandani, David Hirshleifer \& Ivo Welch, Learning from the Behavior of Others: Conformity, Fads, and Informational Cascades, 12 J. ECON. PERSP. 151 (1998).

270. See Cass R. Sunstein, Deliberative Trouble? Why Groups Go to Extremes, 110 YALE L.J. 71, 97-116 (2000).

271. One might also hypothesize that young scholars have sorted themselves out among competing offers to join faculties of law with which they feel more comfortable, who share their way of viewing the legal world.

272. An example Sunstein gives is this:

In many places, feminism appears to have succeeded through a kind of informational cascade, as people who would otherwise be skeptical or unsure came to think that feminist approaches had something to offer-not (in many cases) because they carefully investigated the underlying claims and believed that they were illuminating or right, but because the beliefs of others seemed hard to resist for those lacking a great deal of confidence in their own (skeptical) judgments. If so many people seemed to think feminist approaches to law were valuable, mustn't they be right?

Sunstein, supra note 268 , at 1255.

273. See id. at 1256.

274. See Sunstein, supra note 270 , at 74 .

275. Id. at 74 . 
tional or reputational cascade so that once such a cascade has begun and enough of a group has coalesced around a new custom or fashion, the polarization that occurs within groups will inevitably push the group to the most extreme views within the group. ${ }^{276}$

There are several problems with these two factors as an explanation of scholarly innovations. First and most troubling, this explanation does not distinguish between successful and unsuccessful innovations. Sunstein implies that all legal scholarly innovations in the United States of the last half-century have been the result of information and reputational cascades. And yet some of those cascades have resulted in seemingly lasting innovations, such as law and economics, and others have virtually disappeared, such as critical legal studies. ${ }^{277}$ If they all began in the same manner, why did some succeed and others fail? Sunstein reports that when he served as a visiting professor at Harvard Law School in 1987, critical legal studies was on everyone's lips, both faculty and students. ${ }^{278}$ And yet he also reports that by 1989 the field had disappeared (although some practitioners remain). ${ }^{279}$

What could have happened so forcefully in those two years to kill what seemed to be a popular innovation? Even granting that there are informational and reputational cascades, there is still an important question as to which cascades peter out and which gather strength and become more than mere fads. Sunstein's suggestion that external shocks are a central factor, ${ }^{280}$ while no doubt important, inappropriately, in our opinion, ignores the institutional factors that protect scholarly disciplines from wild swings. Among the institutions that serve that function are promotion and tenure decisions, peer reviewing, competition among scholars for influence and prestige, student evaluations, scholarly conferences, and the general oversight that the university administration provides of its constituent units.

Second, we believe that Sunstein pushes the "group polarization" button too hard. Recall that that phenomenon suggests that within a group of like-minded people, the group tends to drift toward the most extreme opinions within the group. ${ }^{281}$ There is ample evidence in favor of that view in

276. See id. at $82-85$.

277. The first sentence of Sunstein's Michigan Law Review article is "Why did critical legal studies disappear?" Sunstein, supra note 268 , at 1251.

278. See id. at 1255 . We are thankful to Daria Roithmayr for pointing out to us that Sunstein is not suggesting that critical legal studies prospered only from 1987 to 1989 . She (and others far more familiar with the CLS literature than are we) date the beginning of CLS from 1977. See, e.g., KELMAN, supra note 28 , at 1.

279. See Sunstein, supra note 268, at 1255 . See also Robert C. Ellickson, Trends in Legal Scholarship: A Statistical Study, 29 J. LEGAL STUD. 517 (2000), for empirical evidence on the relative health of various scholarly innovations in law.

280. See Sunstein, supra note 268, at 1261-63.

281. See Sunstein, supra note 270 , at 74 . 
the experimental psychology literature. ${ }^{282}$ We do not question that. But we are skeptical of its applicability to the fiercely independent faculty with whom we are familiar on law school faculties. We have already stressed the fact that law schools rarely tip entirely or nearly entirely to extremes on any dimension. ${ }^{283}$ Diversity of viewpoint and opinion is an independent value widely shared on law school faculties. Even within groups of specialists on a faculty there is rarely unanimity of opinion. One of the most attractive aspects of scholarly conferences, even among specialists, is the civil but vigorous manner in which parties sharing the same general point of view can disagree. Those conferences are not, as the group-polarization view might seem to suggest, groupthink reinforcement sessions.

Third, Sunstein's explanation for scholarly innovations may apply to law (with the caveats of the previous paragraphs), but it does not strike us as a general theory applicable to other disciplines within the academy. We have an old-fashioned faith in the steady and cumulative progress of science, and that faith, while it does have room for informational and reputational cascades, suggests that it is descriptive, explanatory, and predictive power that ultimately rule in a competitive academy. We have, indeed, argued that the same factors apply to the law, which leads us to believe that if Sunstein is correct, it is only in a few rare examples within subfields of the law and for relatively brief periods of time, as his account of critical legal studies suggests.

\section{K. Summary and Conclusions}

In this part, we have canvassed a large number of factors that might explain the widespread perception that the U.S. legal academy is much more open to scholarly legal innovations generally and law and economics particularly than are other legal academies around the world. One might have attributed different degrees of plausibility to many or most of these factors. But our examination of them suggests that there is really only one factor that appears to be crucial-having a competitive market in legal education particularly and in higher education generally. Other factors that might seem to play a determinative role, such as the level of compensation of law professors relative to compensation of attorneys and the presence of a prior legal realist revolution, are, ultimately, derivative of whether the legal academy is competitive.

282. See id.

283. See supra Subpart IV.A. 


\section{A MODEL OF THE MARKET FOR LEGAL INNOVATION}

In this part we relate the discussion of legal scholarly innovations to the economic theory of innovation and diffusion. We first summarize the central elements of that economic theory and then show how each element relates to the factors we identified in the previous parts of this article.

\section{A. The General Elements of the Economic Theory of Innovation}

The economic theory of technological innovation teaches us that the production and adoption of an innovation depends on a conjunction of three factors: demand, supply, and market structure. ${ }^{284}$

The determinants of the demand for innovation include the benefits anticipated by the user, the price of the innovation and any other costs of adoption, the availability and costs of complementary skills and inputs, the market strength of the innovative firm with respect to potential consumers, and network effects. ${ }^{285}$ Network effects are more substantial with a general purpose technology due to the wider availability of complementary goods. ${ }^{286}$

An important point of the economic literature of diffusion is that the decision taken by potential adopters is generally not between adopting and not adopting, but rather between adopting now or later. ${ }^{287}$ Furthermore, adoption is usually an "absorbing state" in that relatively new innovations are not replaced by abandoned technologies. ${ }^{288}$ These conclusions are, of course, subject to the presence and absence of some of the supply and market structure determinants, to which we now turn.

The supply determinants of innovation and diffusion begin with the rate of return on the innovation-the increased profits that firms that adopt the innovation can anticipate-and run through the potential for new commercial uses or follow-on inventions from the new technology, the development of complementary inputs, such as user skills (through, say, training courses for new users) and other capital goods. ${ }^{289}$ At the same time, it is possible that a new innovation will induce improvements in older, competing technologies and that those improvements may retard the shift to newer technologies.

284. See Bronwyn H. Hall, Innovation and Diffusion, in THE OXFORD HANDBOOK OF INNOVATION 459, 468-77 (Jan Fagerberg, David C. Mowery \& Richard R. Nelson eds., 2005).

285. Id. at 469. By "network effects" we mean the benefits (independent of other benefits) of using the same technology as others in the industry. For instance, there may be substantial benefits within an organization of all members' using the same computer programs (not necessarily the best such programs) to compose documents, send and receive e-mail, draw graphics, and so on.

286. Id.

287. Id. at 465 .

288. Id.

289. See id. at 469-75. 
The market structure in which the consumers and suppliers interact has a third, profound influence on innovation and its diffusion. ${ }^{290}$ Of the aspects of market structure, the most important in having an effect on innovation is the presence of market power ${ }^{291}$ An old and vexing question in the economics of innovation is, "Does monopoly encourage or discourage the innovation process?" On the one hand, monopolies will be able more effectively to appropriate the return and reduce the potential risk of new technologies than will a competitive industry. That is one reason that we hold out the promise of monopoly status to those who develop and register "novel, useful, and nonobvious" 292 inventions. On the other hand, competitive firms may have a stronger incentive to innovate than do monopolies. Monopolies may also have a reduced incentive to innovate if they have many resources, including human capital, sunk in the old technology. Additional market structure factors that may influence the incentive to innovate are whether and how the firms in the industry are regulated (are there regulations governing such aspects as the number of outputs; entry into the industry through, say, licensure or satisfaction of the "publicconvenience and necessity"; $; 93$ allowable inputs; and the quality grading of the product? ${ }^{294}$ ), whether the industry operates in a local, regional, national, or international market, whether the industry has adopted collective technological standards, and the like.

We use the economic theory of technological innovation to assess the success of innovations in the market for legal innovations, including law and economics. Therefore, we believe that the success of the market for legal innovation in the United States, and the corresponding failure in Europe can both be explained by a detailed analysis of the appropriate demand, supply and market structure aspects in the two regions.

We recognize that the success-versus-failure story might be too stark: it could merely be a question of different paces of change in the United States and Europe. In that case, using the economic theory of technological innovation, the quest is for why the life-cycle of legal innovations is different in the two regions and why diffusion is quicker in achieving the necessary critical mass in the United States. Our theory is compatible with both the success-versus-failure and the slower-pace-of-adoption views.

290. Id. at $476-77$.

291. See id.

292. BLACK'S LAW DICTIONARY 1156 (8th ed. 2004) (listing three factors an invention must possess in order to obtain a patent).

293. Id. at 1265 (describing an often used standard for regulations).

294. The market for legal innovations may be heavily affected by misguided regulations that distort demand and supply determinants, creating a government, rather than a market, failure. We do not here discuss the merits or demerits of those regulations; we simply note that such regulations may play an important role in explaining differences in the national and regional production and adoption of innovation. 


\section{B. Demand Determinants of Legal Innovation}

The direct consumers of innovations in legal theory are, ultimately, those who produce or practice law, including lawyers, judges, and legislators. ${ }^{295}$ Although business and general consumers are indirect consumers of innovation in legal theory, they have a marginal role in the choice of adopting a new legal technology. We shall examine the incentives for adoption of a legal innovation facing each of these groups.

Lawyers are an important group of consumers of innovations in legal theory, but their priority is for innovations that have implications for practice and hence increase the profitability of the provision of legal services. The market for legal services is much more regulated in Europe than in the United States, although one should not minimize the influence of the ABA. ${ }^{296}$ Furthermore, the legal profession in Europe has consistently opposed the so-called commercialization of lawyers. ${ }^{297}$ Many European law societies explicitly criticize deregulation of legal services because they do not want to become more similar to North America which many Europeans consider to be a bad model for the legal profession. ${ }^{298}$ Nonetheless, there has been innovation in legal practice in Europe, and it has been clearly driven by outside competition-principally with U.S. law firmsand by the increasing complexity of the world, rather than by intrajurisdiction competition. ${ }^{299}$

The influence of the market for legal services and law firms in European legal policy-making has, until quite recently, been very limited when compared to America and a much-less-powerful influence than it has been in the United States. For example, drafting of the law and legal policy discussions in Europe are still primarily led by law professors and bureaucrats, and much less by practitioners or law-firm lobbyists. ${ }^{300,301}$

295. We have already examined the incentives facing the producers of these innovationsprofessors. Another group of interested consumers of legal innovation is prosecutors. In Europe, given the way the court systems are organized, we believe that prosecutors have similar incentives to those facing judges for adopting innovation.

296. See Nuno Garoupa, Regulation of Professions in the US and Europe: A Comparative Analysis 24-25 (Am. Law \& Econ. Ass'n Annual Meetings, Working Paper No. 42, 2004), available at http://law.bepress.com/alea/14th/art42/; see also discussion supra note 190.

297. Garoupa, supra note 296, at 16-17.

298. Id. at 25 .

299. Id. at $15,18,20,21$.

300. For example, legal drafting is usually a matter for law professors and law commissions in France, and for high-ranking bureaucrats in the United Kingdom. See generally STEINER, supra note 181, at 13-22 ("compar[ing] and contrast[ing] . . the French style of legal drafting with the English one"). A United Kingdom governmental report will usually be given the name of the bureaucrat who wrote it, leading to a common complaint by scholars in the United Kingdom that academic work and research is usually ignored by these high-ranking bureaucrats.

301. Another important difference in legal policy-making between the United States and Europe is the influence of private lobbying on legislation and regulation and the involvement of law firms in the process of lobbying. Only at the level of European rather than national law (due to the fact that most 
At the same time the legal profession in Europe faces fairly segmented markets with three important consequences. First, competition between legal systems and practices across U.S. states has taken place much earlier and much more vigorously than has competition for legal services across European countries. There is no competitive federalism in the legal sense in Europe. Second, until quite recently, the legal profession in Europe has been, by regulation, kept compartmentalized from other professions that may provide services complementary to the market for legal servicesauditors, accountants, tax advisors, financial services providers, estate planners, and the like. As a result, law firms in Europe cannot easily realize complementarities across all the services their clients need as easily as can the more integrated and less compartmentalized U.S. law firms. So, U.S. law firms generally demand greater innovation than do European law firms. Finally, European public administrations have been one of the main recruiters of law graduates, relatively much more so than private law firms. The situation is exactly the opposite in the United States. Because public administrators probably have far less incentive than do private profit-maximizing law firms to innovate in their legal practice, the demand by lawyers for innovative legal theory is likely to be much less in Europe than in the United States.

Judges are a fundamental group of consumers of legal innovations for two reasons. On the one hand, innovation in legal theory is important for judges to have so that they might have a comprehensive and evolving view of the law and so that they can see solutions to new controversies, such as those arising in cyberspace. On the other hand, the adoption of a legal innovation by judges will push other participants in the legal system (lawyers, prosecutors, and even legislators through a feedback effect) to use identical technology. In a sense, judges are pivotal consumers of legal innovations: their adoption of an innovation generates network effects. ${ }^{302}$

It is well documented that U.S. judges are much less restricted and more bold in judging than are their European counterparts. ${ }^{303}$ To take only one example, U.S. judges have broader subject-matter jurisdiction (civil, criminal, administrative, and constitutional). ${ }^{304}$ These differences are due not only to the differences between common and civil law, but more fundamentally to the less-fluid organization of the judicial profession in Europe. ${ }^{305}$ There the judiciary is a hierarchical bureaucracy with strict professional and behavioral norms and is, somewhat surprisingly, more

European Union legislation is business-oriented) do we observe huge spending by companies on influencing legislation and the use of law firms to promote their views.

302. See Ogus, supra note 259 , at 429-32.

303. Ronald J. Krotoszynski, Jr., Constitutional Flares: On Judges, Legislatures, and Dialogue, 83

MINN. L. REV. 1, 35 (1998).

304. See POSNER, LAW AND Legal THEORY, supra note 144, at 84, 112.

305. See id. at 89-90. 
dependent on and subservient to the political process than are U.S. judges. ${ }^{306}$ As a result, European judges are politically weaker than U.S. judges. The situation in England and Wales is more complicated than this stylized picture, although Posner suggests that in practice English and Welsh judges are more similar to continental European than to U.S. judges. ${ }^{307}$

A good example of the differences between the United States and Europe, as they affect the demand for legal innovation, is the use of citations by judges. Whereas in the United States it has become common practice to use citations to evaluate judicial performance, ${ }^{308}$ nothing of this sort happens (or is likely to happen) in Europe. A tradition of the civil law courts is not to cite other judicial opinions and doctrinal articles, a practice that not only makes it very difficult to trace the influence of different innovations but also reduces the incentive for judges to enter actively in the market for ideas in legal thinking.

Our analysis suggests that in Europe adoption of a new legal innovation would be diffused quickly if judges were receptive to it. The innovation would, in turn, trickle down into teaching and scholarship very rapidly. On the other hand, if judges are not very receptive to innovations generally, then it is highly unlikely that others will generate innovations for judges to use.

Legislators are consumers of innovation in legal theory inasmuch as it helps them to produce new legislation within a coherent body of law. Therefore, the production of legislation plays an important role in the selection and implementation of legal innovations. Indeed, we suspect that if legal innovations are adopted in Europe, they will be adopted principally by legislators or those involved in the legislative process. ${ }^{309}$

In Europe, the influence of law professors in the drafting of the law plays an important positive role in the legislator's decision to adopt an innovation. When the production and evaluation of legislation relies on

306. See id. at 107.

307. See id. at 20-37; Dau-Schmidt \& Brun, supra note 113, at 611-15. The latter authors argue for a similar thesis to ours on the basis of the facts that the United Kingdom has no written constitution and adheres to the doctrine of Parliamentary sovereignty. Both practices facilitate a strong legislature at the expense of a weak judiciary with a limited role in the interpretation of the law.

308. See, e.g., Stephen J. Choi \& G. Mitu Gulati, Choosing the Next Supreme Court Justice: An Empirical Ranking of Judge Performance, 78 S. CAL. L. REV. 23, 30 (2004); Stephen J. Choi \& G. Mitu Gulati, Mr. Justice Posner? Unpacking the Statistics, 61 N.Y.U. ANN. SURV. AM. L. 19, 27 (2005); Stephen Choi \& Mitu Gulati, A Tournament of Judges?, 92 CAL. L. REV. 299, 303 (2004); Stephen J. Choi \& G. Mitu Gulati, Which Judges Write Their Opinions (And Should We Care)?, 32 FLA. ST. U. L. REV. 1077, 1084 (2005); Mitu Gulati \& Veronica Sanchez, Giants in a World of Pygmies? Testing the Superstar Hypothesis with Judicial Opinions in Casebooks, 87 IowA L. REV. 1141,1154 (2002).

309. For example, the expansion of cost-benefit analysis (the so-called regulatory impact assessment) as a legislative tool in Europe has been completely ignored by law schools and law professors in general. 
law professors and legal experts, legislators will tend to adopt legal innovations suggested by these intermediaries, but not by third parties. Therefore, law professors and legal experts can exert control through their close access to the market for legal innovation. This effect will be more important if legislators are the main producers of law and law professors are the main advisers, which is the case in continental Europe, but not traditionally in common law jurisdictions as we have seen.

Our analysis suggests that these groups of consumers-lawyers, judges, and legislators-have a relative weight in the demand for legal innovation that is quite different in Europe and the United States. We believe, further, that the immediate return to the adoption of any legal innovation is not high in Europe for many of these consumers. Private returns for adoption of legal innovations are relatively lower in Europe than in the United States because there is a lack of network effects, particularly because of the more rigid and hierarchical organization of judges considered as consumers. Consequently, innovative consumers have a weaker role to play in Europe than in the United States and are, therefore, likely to defer adoption.

All this notwithstanding, it could be the case that the social return to legal innovations could be as high in Europe as in the United States but that the imperfections of the private market or of governmental regulations make it more difficult for Europe to bring private and social return into alignment than is the case in the United States. If so, then it might be the case that certain external shocks on Europe, such as a quickened pace of competition across national borders in the higher-education market, could quickly change that state of affairs-that is, correct the misalignment between private and social return. Even without those shocks, it is highly likely that some of the causes of such misalignment will gradually disappear as countries reform the legal and judicial professions as well as lawdrafting techniques.

The European Union in itself can be regarded as a positive external shock on the demand for legal innovation by consumers. First, the opening of the market for legal services to competition has put pressure on lawyers and law firms to adopt more efficient technology in terms of legal innovation. European lawyers are increasingly working in international contracts, and business-related litigation is making more use of EU law and EU legal institutions and bodies. ${ }^{310}$ We should notice, however, that some practice areas are under more pressure than others: for example, the area concerned with a facilitative role for economic transactions within the European Union is more demanding of legal innovation (through business and

310. See PAUl CRAIG \& GRálnNe DE BúrCA, EU LAW 70 (3d ed. 2003) (discussing how the jurisprudence of the ECJ is business-biased because most preliminary rulings relate to business-related litigation). 
financial law, corporate law, and contract law) than are areas less touched by economic integration factors (such as procedural or criminal law). ${ }^{311}$

The private returns to innovation in the judicial profession have increased as national courts become partners in the production of EU law. ${ }^{312}$ National prevailing doctrines cannot easily accommodate EU and national law in a comprehensive setup without substantial change, and that integration of EU and national law has given rise to a great demand for innovation. ${ }^{313}$

EU membership has also had a positive impact on the demand for legal innovation by legislators. On the one hand, the drafting of EU directives, the implementation of those directives by national legislatures, and the incorporation of European Court of Justice (ECJ) jurisprudence have all affected the production of law by national legislators, in the formal sense by the recognition of the supremacy of EU law and in the practical sense by requiring, among other things, regulatory impact assessment or environmental impact analysis in many contexts. On the other hand, the pressure for control of public expenditure has pushed governments to consider reforms of the judicial and legal systems. ${ }^{314}$ Additionally, there is an increasing recognition that a nation's legal system may be a major determinant of investment and economic competitiveness. ${ }^{315}$

With respect to the demand for innovation in legal theory, the European Union has certainly represented a shift in "legal technology transfer" by decreasing the cost of adoption and increasing the private return to such adoption. ${ }^{316}$ But there may be confounding effects arising from the move into unification or harmonization of several areas of the law. If that view

311. See generally Nuno Garoupa \& Anthony Ogus, A Strategic Interpretation of Legal Transplants, 35 J. LEGAL STUD. 339 (2006); Ogus, supra note 259.

312. See CRAIG \& DE BURCA, supra note 310, at 301-04, on the willingness of English judges to review Parliamentary legislation (against the so-called "principle of Parliamentary sovereignty") by overturning it (technically not applying it) when it is inconsistent with ECJ jurisprudence. Apparently, it took more time for French and German judges to indulge in such behavior, which is not surprising given the organization of the judicial profession in civil law countries. For a more general discussion of U.S. strong-form judicial review and the new European weak-form judicial review, see Mark Tushnet, Judicial Review of Legislation, in THE OXFORD HANDBOOK OF LEGAL STUDIES, supra note 86 , at $164,174-78$.

313. Not surprisingly, mandatory education in EU law has yet to meet widespread acceptance. Quite recently, in a letter to the President of France, forty well-known French law professors have rejected EU law as law that deserves to be studied and analyzed. Only French law should be taught at French law schools according to these law professors. See Alexandre Ciaudo, Division de la Doctrine Française, A Propos d'un Excès de Pouvoir Communautaire, http://www.blogdroitadministratif.net/index.php/2007/01/21/132-division-de-la-doctrine-francaise-apropos-dun-exces-de-pouvoir-communautaire (last visited Apr. 13, 2008).

314. EU treaties "impose budgetary constraints and disciplines on the Member States, making them think long and hard about spending priorities and the role of the state in the economy." Claus-Dieter Ehlermann, State Aids Under European Community Competition Low, 18 FORDHAM INT'L L.J. 410, 421 (1994).

315. See Rafael La Porta, Florencio Lopez-de-Silanes, Andrei Shleifer \& Robert W. Vishny, Law and Finance, 106 J. POL. ECON. 1113, 1114-15 (1998).

316. There is plenty of evidence of opposition by the incumbents to entrants confirming that "legal technology transfer" is important. See Ogus, supra note 259, at 422-29. 
triumphs to the exclusion of the fostering of a "competitive federalism," then the demand for innovation could be seriously reduced.

In summary, we recognize that the demand determinants for legal innovations are quite different in the United States and Europe. As we shall soon see, however, we argue that these differences are much less important than the differences in supply determinants.

\section{Supply Determinants of Legal Innovation}

The producers of scholarly legal innovations are primarily law professors. We have already hinted at the striking differences between legal professorships in the United States, United Kingdom, and continental Europe ${ }^{317}$ Here we elaborate on the impact of these differences on the incentives to supply legal innovations.

The first aspect to consider is the career and promotion of law professors and thier effects on the entrenchment of the legal academic status quo. There are three supply-side factors that are particularly important in explaining the incentives facing the legal professoriate in the United Kingdom and continental Europe: (1) the rigidly hierarchical relationships within the academy; (2) the lack of any meaningful academic mobility (in particular, lateral mobility); and (3) the facts that law reviews are facultyedited and directed at practitioners and that law reviews and law books tend to be published in the jurisdiction's native language.

In Europe, the market for new law professors has a surface competitiveness but a deeper sense of entrenching the status quo. Dissertations-a Ph.D. (and, in Germany, a habilitationschrift) in law being a requirement for an academic appointment-tend to be a replication by young, ambitious candidates of the former generations' influential work and not overly original scholarship. In contrast, in the United States, the academic job market for law schools is extremely dynamic and highly competitive, and the production of innovation in legal theory is primarily published in student-edited law reviews that are less prone to capture by professional cartels. ${ }^{318}$ Neither European nor American law reviews follow the standard approach to academic periodicals used in the hard sciences and most of the social sciences-that of peer review and the revise-and-resubmit treatment of articles. ${ }^{319}$

The mobility of law professors within European countries, with the possible exception of the United Kingdom, is also not stimulated by the combination of in-breeding in many countries (the hiring by universities of their own best students) and the fact that a university professor is essen-

317. See supra Subpart IV.E.

318. See Dau-Schmidt \& Brun, supra note 113, at 609.

319. See supra note 212 and accompanying text. 
tially a civil servant or a lawyer working for a public administration body. Under these conditions, there are all of the usual incentive problems in compensating excellent academic performance. For example, starting salaries in law schools are quite low compared to those in private law firms or, in many European countries, the judiciary ${ }^{320}$ And there is very little later in a European law professor's career that allows for recognition of superb scholarship. There have been, for example, outside of the United Kingdom very few, if any, endowed professorships in law.

In the United States over the past thirty years or so, there has been a dramatic increase in the number of law professors. ${ }^{321}$ This increase has put pressure on younger professors to adopt new legal technologies as a way to get a distinct reputation within the profession. ${ }^{322}$ This is in clear contrast with the United Kingdom, where England has had no similar pattern of development of chairs in law in the period 1870 to 1960 and, until the late 1980 s, very little expansion in the number of law schools. ${ }^{323}$

Putting together all these observations, we conclude that while in the United States a young ambitious law professor must get noticed and known (a powerful incentive to be creative and innovative, if not controversial, thus providing a heterogeneous supply of legal innovations), in Europe the same candidate strives to be admitted to the exclusive club of law professors (hence a powerful incentive to replicate rather than innovate, thus creating a homogeneous supply of legal innovations). Furthermore, the nature of the risks in the academic profession might also indicate that legal scholars would be more risk-averse in Europe than in the United States, hence further reinforcing the incentives against innovation.

A second important and related observation concerns the profile of law professors in the United States, where law is a professional, postgraduate degree, and in Europe (including the United Kingdom), where law is an undergraduate degree. ${ }^{324}$ In the United States, law professors have a bachelor's degree in arts or sciences, but not law; as a result, they are exposed to different methodologies and are more heterogeneous in terms of scientific background. ${ }^{325}$ Many law professors combine a J.D. degree

\footnotetext{
320. Although there are universally recognized good law schools in Europe, there is no Europewide, and in most cases, no national ranking of law schools. (The United Kingdom is an exception. See infra note 328.) As we have explained before, part of the problem has to do with a lack of consensus over how to evaluate legal research across Europe, a situation completely at odds with the state of affairs in the field of economics, and, apparently, in the field of legal scholarship in the United States.

321. See Richard A. Posner, Legal Scholarship Today, 115 HARV. L. REV. 1314, 1324 (2002).

322. See id. at 1321; Ulen, supra note 122, at 38-39.

323. Duxbury, supra note 231, at 965. The first professorship of English law may have been established at Oxford in 1758, and two centuries later there were around 200 teachers of law in the United Kingdom (as measured by membership of the U.K. Society of Public Teachers of Law, the equivalent of U.S. Association of American Law Schools). Id.

324. See supra Subpart IV.D.1.

325. See supra Subpart IV.D.1.
} 
with a Ph.D. in a social science such as economics or political science or in liberal arts such as history or literature. ${ }^{326}$ In Europe, law professors have a bachelor's degree in law and are hence much more homogeneous in scientific background. ${ }^{327}$ Typically post-graduate studies in law (LL.M. or Ph.D.) are not combined with other degrees.

It is not uncommon for law professors to clerk for a judge or practice in a law firm before embracing a career at a law school. In Europe it is typically the other way around: they become law professors and then go into practice. The time devoted to research and to the production of innovations in legal theory is more constrained by outside options in Europe than in the United States. ${ }^{328}$

The typical profile of law professors in the United States explains why law schools are more heterogeneous and more open to the influence of other scholarly fields, including economics. Conversely, the more homogeneous profile of law professors in Europe (including the United Kingdom) tends to close law schools to outside fields. ${ }^{329}$ As a result, the switching costs of new legal technologies generated by scholarly innovations are higher in Europe than in the United States. Legal innovations, such as law and economics, require investment in highly complex complementary skills that are more often available in the United States than in Europe.

There is another, related academic phenomenon that is worth remarking: notice that for the last twenty-five or more years economics departments in the United States have been exporting specialized economists to professional schools (law, medical, business, and public policy). Typically, but not always, these economists receive better salaries than if they were to remain in departments of economics. This same staffing of professional schools by economists is not occurring in Europe, where salaries are less competitive and traditionally fixed across departments in public universities. With particular reference to economics, we should not forget that in some continental European countries, departments of economics originally split off from law schools and that chairs in political economy or public finance were in law schools in the early 1900 s.

326. See supra text accompanying notes 69-72.

327. See supra Subpart IV.D.1.

328. The United Kingdom is an exception in Europe because of the national Research Assessment Exercises (RAE) that have been implemented over the last twenty years. These exercises necessarily improve performance but also support entrenchment. Moreover, the law panel of the RAE, contrary to the practice of the panel in economics, for instance, has recognized case notes, loose leaf works, and books written as being able to exhibit significant scholarly material in addition to peer-refereed journals and other indicators closer to hard sciences. William Twining, Ward Farnsworth, Stefan Vogenauer \& Fernando Tesón, The Role of Academics in the Legal System, in THE OXFORD HANDBOOK OF LEGAL STUDIES, supra note 86, at $920,925$.

329. In Europe, one frequently hears the argument against economic imperialism as part of the opposition to innovations with economic content. 
Another important aspect to bear in mind is the organization of law schools within a broad market for legal education. In the United States, law schools do not enjoy local or spatial monopoly. Rather, they aim to attract the brightest candidates from all over the country and, indeed, from all over the world. ${ }^{330}$ In the United Kingdom and continental Europe, law schools compete to some small degree for quality students, but they produce lawyers for a national jurisdiction. ${ }^{331}$ Therefore, the approach to legal education is more jurisdiction- and practitioner-oriented, whereas in the United States the top schools promote a legal education that is more friendly to the general understanding of law and is therefore portable across jurisdictions. ${ }^{332}$ Another way of putting it is that in Europe law schools teach "statistics" (legal formalism), whereas in the United States they teach "science" (legal policy making). It is of no surprise that innovations in "science" are more important and more frequent than innovations in "statistics." 333

We could argue that the return on innovation in legal theory is higher for any level of supply in the United States than in Europe. Furthermore, the lack of a prevailing doctrine certainly increases the possibility of new uses for the technology and the development of complementary inputs (such as spillovers into other areas of the law). At the same time, it is possible that a new innovation will not induce much improvement in older competing technologies because there is no obvious prevailing old technology.

At the European level, we can observe two important external shocks on the supply of innovations in legal theory. One important factor is the pending integration of the higher education market in Europe through the so-called "Bologna agreement." 334 However, at this point it is not clear

330. Notice the contrast between top American law schools and middle-ranked law schools. These latter schools are much more vocationally oriented and are very similar to law departments in the United Kingdom Almost no law and economics is taught or produced in those middle- and lowerranked schools. Their student bodies are typically drawn from a more localized area, and their placement of their graduates is also typically in local or regional law firms.

331. This is not exactly true for the United Kingdom, since England and Wales are different from Scotland and Northern Ireland, but England and Wales have a disproportionately large weight over the other two jurisdictions in terms of the production of lawyers.

332. Here the counter-examples should be Canada and Australia. The hybrid nature of Quebec law and the federal nature of Canada create a very rich framework for general understanding of law rather than jurisdiction practitioner-oriented schools. Nevertheless, the pace of legal innovation in Canada is quite slow compared to the United States. A similar point can be made on Australia. See Roy M. Mersky \& Jonathan Pratter, Comparative Observations on Doing Legal Research in Australia and the United States, 7 AUS. L. LIBR. 175, 175-81 (1999).

333. We could easily argue that we have been teaching economics rather than economic statistics in Europe for more than fifty years now. In that respect, law has not yet made such transition. One reason for this is that Europeans have recognized American leadership in economic growth and business innovation quite early; they have not recognized yet American leadership in legal thinking and innovation.

334. EU RECTOR'S CONFERENCES \& ASS'N OF EUROPEAN UNIV., THE BOLOGNA DECLARATION ON EUROPEAN SPACE FOR HIGHER EDUCATION: AN EXPLANATION (1999), available at http://ec.europa.eu/education/policies/educ/bologna/bologna.pdf. 
whether this integration will generate a "race to the bottom" or a "race to the top." We have each been present at discussions among European law professors at which there has been spirited disagreement about whether the imposition of the Bologna agreement will lift European legal education onto a world stage or ruin it. Incidentally, those who take the "race to the bottom" view tend to be traditional doctrinalists, while those who take the "race to the top" view include the most prominent law-and-economics scholars or those who are active in international legal circles. Certainly, if the outcome is further cartelization of higher education, the results will not be promising for the supply of innovation in legal theory.

A second important factor to bear in mind is the increasingly widespread use of English as the common scientific language, even in law. ${ }^{335}$ Europe-wide law reviews tend increasingly to be published in English, although most law reviews still are in national languages. ${ }^{336}$

\section{Market Structure Determinants}

So far we have described the U.S. supply and demand for legal innovation as being greater and more diffuse than European supply and demand. We have also emphasized that we suspect that supply-side determinants are more powerful than demand-side determinants. We look now at important market structure determinants.

The market structure for legal innovation is determined by the bargaining power of demanders and suppliers, by the number of firms in the industry, and also by government intervention by means of regulation of the legal and judicial professions, the organization of law schools, and the allocation of resources for research in legal theory. In Europe (except in the United Kingdom) research funds are primarily public and are principally allocated in a relatively fixed manner across disciplines and departments. ${ }^{337}$

In Europe, both demand and supply are more homogeneous than in the United States, thus creating a typical situation of bilateral oligopoly. In the United States, demand and supply are more competitively dispersed and heterogeneous. Consequently, in Europe there are prevailing doctrines that make incumbents strong and challengers weak and struggling to survive. Producers provide fewer innovations and consumers delay adoption to later periods waiting for higher returns. In the United States, as we have seen, there have been traditionally more innovations, including legal real-

335. See supra Subpart IV.E.1.

336. It could be that demand-side pressure, more than a direct change of supply incentives, has made it more difficult for legal scholarship to confine attention in its scholarly publications to just one jurisdiction. Whichever factor is more important, we certainly do not mean to suggest that "we are all comparatists now." Twining et al., supra note 328, at 921 (quoting WILliAM TwiNING, GLOBALISATION \& LEGAL THEORY 255 (2000)).

337. See supra note 128. 
ism, law and economics, critical legal studies, and the different "law and" movements.

A particularly striking characteristic of regulation of the market for innovation in legal theory is the use of national symbols (language, culture, and history) to avoid entry, the need to devaluate comparative analysis or external influence (the criticism of transplants; the emphasis on solutions rather than on problems, thereby undermining the need for comparative analysis) together with path dependence (legal innovations must address the issues raised by the legal code constructed by a previous legal technology, most research being commentaries on domestic law for domestic audiences), altogether bordering on pure rent-seeking. ${ }^{338}$

We can summarize the parochialism of legal thinking under the standard statement that " $[n]$ o one can truly know a legal system other than that of her own country." tionism in the market for legal innovations. We know from the literature on international trade that social welfare losses caused by protectionism are significant, and the dynamics of rent-seeking that protectionism creates introduces important distortions in markets and in policy-making.

The big difference between the United States and Europe is not the protectionist nature of legal thinking. ${ }^{340}$ The problem is the size of the protected market. ${ }^{341}$ There are, of course, localized, parochial law schools in the United States that disdain scholarly innovation. But the number of law schools and the competitive nature of the higher echelon of law schools still leaves room for the social-welfare-enhancing aspects of competition due that we have identified. In European countries, protectionism badly hurts the market for legal innovation because each jurisdiction has a too small market to generate the competitive incentives that are required for the quick production, adoption, and diffusion of innovations.

In principle, European integration will exert a positive effect by reducing parochialism. Not surprisingly, there has been a profound impact of law and economics on competition policy on in the EU. Law and economics might also have a profound impact on corporation law in the European

338. See H. Patrick Glenn, A Transnational Concept of Law, in THE OxFORD HANDBook of LEGAL STUDIES, supra note 86 , at $839,839-46$ (discussing the incremental effort to provide a denationalization of law and the problems encountered by transitional approaches and legal tradition).

339. Mersky \& Pratter, supra note 332, at 175 (quoting an anonymous speaker).

340. Several authors, for example, have argued that the American Supreme Court is more parochial than the Australian High Court or the New Zealand Court of Appeal. See, e.g., id. at 176.

341. In fact, we can argue that bilateral protectionism reinforces itself. Many Europeans see law and economics as essentially a U.S. product, whereas many Americans refer to their work as American law and economics in opposition to, we would guess, European law and economics. It is of interest to note that, for example, contrary to many other handbooks published in other areas of economics by Elsevier, 1 Handbook of LAW AND Economics (A. M. Polinsky \& Steven Shavell eds., 2007), does not have a single author or co-author with a European affiliation. 
Union. ${ }^{342}$ However, harmonization of legal systems would undermine some of the incentives for a competitive market for legal innovation.

We further propose that our model explains the anomalous cases of Israel and the Netherlands to which we earlier drew attention. In both countries, the early and rapid spread of the use of English in higher education, and in legal education in particular, has provided their educational institutions with market characteristics that make them evolve more rapidly than other EU countries.

\section{CONCLUSION}

We began with the stark fact that there is a sharp difference between the receptivity to innovations in legal scholarship in the United States and the rest of the world. The U.S. legal academy generates scholarly innovations at an almost dizzying pace, while the legal academies of the rest of the world seem to be almost immune to innovation. We examined a large number of potential explanations for this difference-ideological biases among faculty, the ability of extracurricular money to purchase innovations, the differences between common and civil law systems, whether legal education is a graduate or undergraduate field of study, the competitive nature of legal and higher education, the level of compensation of the professoriate relative to their expected salaries in private practice, the impact of a commitment to utilitarianism or Kantianism as the default legal philosophy, the presence of a prior legal realist revolution, the role of information and reputational cascades and of group polarization, the influence of legal culture, and the influence of a great man or woman champion for an innovation-and found that the most important factor was the degree of competitiveness in legal education specifically and in higher education generally. If a nation's higher and legal educational sector is competitive within its borders and with similar sectors in other countries, then that sector is far more likely than not to view scholarly innovation as valuable and to create and enforce incentives that foster innovative scholarship.

If the market for legal innovation is able to produce more innovations in the United States than in Europe, then legal thinking should be more productive in the United States than in Europe (since the economic theory of innovation asserts that better technology improves productivity). We firmly believe so, and in that respect we are prepared to argue that law and economics has substantially increased productivity in research in law.

342. We should not disregard here the great man or woman theory. Apparently, for a while, the European Commission was dominated by market-oriented economists dealing with several areas of European law, and law and economics is having an impact through those economists' impact on Commission policy recommendations. It could be that the impact of law and economics will come through law schools' trying to understand what the Commission is up to. 
